\title{
1990 WASTE TANK INSPECTION PROGRAM
}

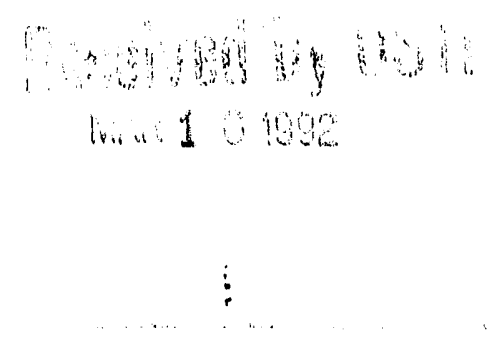

F. G. McNatt

\section{DISCLAIMER}

This report was prepared as an account of work sponsored by an agency of the United States Government. Neither the United States Government nor any agency thereof, nor any of their employees, makes any warranty, express or implied, or assumes any legal liability or responsibility for the accuracy, completeness, or usefulness of any information, apparatus, product, or process disclosed, or represents that its use would not infringe privately owned rights. Reference herein to any specific commercial product, process, or service by trade name, trademark, manufacturer, or otherwise does not necessarily constitute or imply its endorsement, recommendation, or favoring by the United States Government or any agency thereof. The views and opinions of authors expressed herein do not necessarily state or reflect those of the United States Government or any agency thereof. 


\section{CONTENTS}

INTRODUCTION

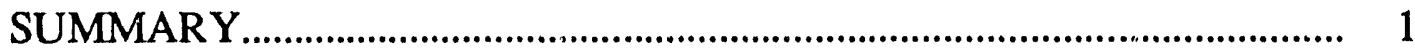

DISCUSSION

Radioactive Waste Management....................................... 2

Inspection Program................................................................... 2

PROGRAM IMPLEMENTATION

Visual Imagery............................................................ 3

Inspection Results............................................................. 3

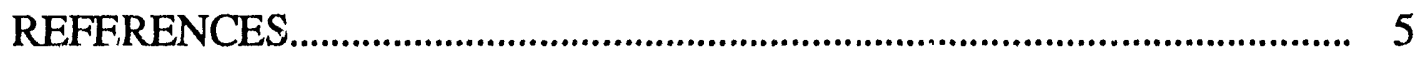

TABLE

1 Summary of Inspections................................................ 6 


\section{INTRODUCTION}

Aqueous radioactive wastes from Savannah River Site separations processes are contained in large underground carbon steel tanks. Tank conditions are evaluated by inspection $(1,2)$ using periscopes, still photography, and video systems for visual imagery. Inspections made in 1990 are the subject of this report.

Period covered: January 1 through December 31, 1990.

\section{SUMMARY}

The 1990 inspection program revealed the condition of the Savannah River Site waste tanks was basically unchanged from that indicated in previous reports.

Two additional crack sites were observed in tank 9. These are cracks that developed before the end of 1960 .

A fourth crack site was confirmed in tank 20 . This site had been suspected of being, a failure since 1984.

Rainwater leaked into the annuli of tanks 9 and 10 changing the configuration and distribution of leaked waste in both annuli.

Rainwater leaked into the annulus of tank 15 reactivating three leaksites. A very small quantity of waste seeped from the primary vessel before the leakage was arrested.

In 1990 a total of 6,156 photographs and 67 visual or video inspections were made: 


\section{DISCUSSION}

\section{$\underline{\text { Radioactive Waste Management }}$}

Aqueous radioactive wastes are contained in large underground carbon steel tanks of two general structural designs. The single containment tanks are circular and they are encased in concrete. The double containment tanks consist of an enclosed primary tank set inside a 5-foot-high secondary catch pan or, in the latest design, a complete secondary tank. The space between the outside of the primary tarik and the inside of the secondary liner is termed the annulus. Inspection ports or risers are located at various positions on top of the primary vessel and above the annulus. Inspection apparatus is lowered through the risers to observe and document: tank conditions.

The radioactivity of the waste requires that the inspection equipment used in both annuli and tank interiors be operated remotely. Details of the equipment and procedures for inspection are contained in DPSP 79-1003 (3).

\section{$\underline{\text { Inspection Program }}$}

The policy developed for photographic inspections in 1972 specifies biennial inspection in the annuli of all tanks and annual inspection of those tanks in which waste has breached the primary vessel. Biennial inspections do not include all annulus risers, so the time required to inspect a tank through all risers could be as long as 4 years. However, the wide angle photography method developed in 1974 was used to make annual inspections in risers which are not scheduled for a more detailed inspection.

The 1990 inspection program used four visual imagery techniques. The primary methods for making scheduled inspections were the direct photography techniques, i.e., the direct photograph technique for making a series of photographs providing detailed views of the tank and the wide-angle photography technique for obtaining overview of large areas of and in the tanks with a single photograph. Closed circuit television systems and periscopes were generally used to further investigate questionable conditions found during scheduled inspections and to troubleshoot process problems. 


\section{PROGRAM IMPLEMENTATION}

Visual Imagery

The wide-angle photographic (WAP) technique was used to inspect and photographically record conditions in all double-wall tanks and in single-wall tanks 18 and 19.

The direct photographic (DP) technique was used to inspect and photographically record conditions in the annuli of double-wall tanks.

Periscopes and closed circuit TV systems (CCTV) were used to inspect and photographically record conditions in single-wall tanks, doublewall tanks and ancillary cells and vessels.

\section{$\underline{\text { Inspections Results }}$}

The 1990 inspection program was successfully completed. The annuli of all double-wall tanks and the interiors of single-wall tanks were inspected at accessible risers by a least one photographic technique.

These inspections revealed that condition of the waste tanks remained virtually unchanged in 1990 . No evidence of corrosion was observed and no new leaksites were found.

In tank 9, two crack sites that developed before the end of 1960 were observed. Both cracks were at a vertical weld high on the top knuckle of the tank, 18 to 23 inches below the tank top. The cracks were evidenced by small deposits of dry leaked waste on the exterior of the primary steel vessel. These are obviously old cracks since the tank content has not been as high as the cracks since 1960 .

Rainwater leaked into the annuli of tanks 9 and 10 changing the configuration and distribution of the wastes that has been in these annuli for many years. Based on inspections made in 1989 it had been assumed that additional wastes had seeped from the primary vessels into the annuli of both tanks. This assumption was made since there was insufficient evidence to indicate another mechanism for the changing configuration of the waste in these annuli. However, weekly inspections of these annuli were continued in 1990 and a 
correlation was established between changes to the wastes and rainfall.

A program has been developed and equipment is being procured to establish continuous monitoring in the annuli of tanks 9 and 10 to determine where rainwater enters these annuli so the leakpaths can be eliminated.

Three leaksites were reactivated in tank 15 . Water leaked into the annulus during August when almost seven inches of rain fell. Subsequent humid conditions in the annulus caused three old leaksites to seep small quantities of waste increasing the volume of dry leaked waste deposited on the exterior wall of the primary vessel. The high humidity also changed the surface configurations of other waste deposits on the tank wall. Of the three sites that seeped additional waste, only one continued to seep after the initial observation made on August 29 . At that site seepage continued until mid December resulting in about $10 \mathrm{cc}$ of dry waste being deposited on the exterior wall of the primary vessel.

In tank 20 another failure in the steel liner was confirmed. This site has been suspected of being a failure since the inspection made on June 27, 1984. Inspection made June 28, 1990 confirmed this site on the east wall twenty-six feet above the tank bottom to be a failure. It is the fourth failure identified in the steel lincr of this tank. Waste was removed from the tank in 1982. All four of the leaksites are at elevations well above the liquid ballast in the tank.

In tank 48 several tests were conducted in an effort to locate the leaksites in the five failed cooling coils as part of the study to determine if the failures were corrosion induced. These tests indicated that cooling coils 3 and 16 had failed inside the primary vessel and 1 and 5 had failed outside the primary vessel. Test to determine location of the leaksite in cooling coil 18 was unsuccessful.

Water marks, stained surfaces, and calcite deposits in the annuli of several tanks (see Table 1) indicated that rain and/or groundwater leaked into these annuli. The inleakage occurred around poor riser plug seals, failed seals where process pipes penetrate tank annuli below grade, and at other locations. 


\section{REFERENCES}

1. ERDA-1537, Final Environmental Impact Statement. Waste Management Operations, SRP pp II-103 through-115.

2. Kiger, E. O., Evaluation of SRP Waste Storage Tanks, DPSPU 73-11-3, May. 1973.

3. McNatt, F. G., SRP Waste Tank Inspection Manual, DPSP 79-1003, January, 1979. 
TABLE 1

SUMMARY OF INSPECTIONS

\begin{tabular}{|c|c|c|c|c|c|c|c|}
\hline \multirow[b]{2}{*}{ Area } & \multirow{2}{*}{$\begin{array}{c}\text { Tank } \\
\text { or } \\
\text { Vessel } \\
\end{array}$} & \multirow{2}{*}{$\begin{array}{c}\text { Inspec- } \\
\text { tion } \\
\text { Port } \\
\end{array}$} & \multirow{2}{*}{$\begin{array}{l}\text { Annulus } \\
\text { or } \\
\text { Interior }\end{array}$} & \multirow[b]{2}{*}{ Date } & \multicolumn{2}{|c|}{$\begin{array}{l}\text { Type of Inspection and } \\
\text { Identification Numbers }\end{array}$} & \multirow[b]{2}{*}{ Remarks } \\
\hline & & & & & WAP & $D P \quad P S P$ & \\
\hline \multirow[t]{4}{*}{$F$} & 01 & East & $A$ & $04 / 06 / 90$ & & $5435: 01-17$ & No change \\
\hline & & North & A & $03 / 15 / 90$ & & $5396: 01-20$ & No change \\
\hline & & South & $A$ & $03 / 19 / 90$ & & 5389:01-17 & No change \\
\hline & & West & $A$ & $03 / 19 / 90$ & & $5390: 01-17$ & No change \\
\hline \multirow[t]{6}{*}{$\mathbf{F}$} & 02 & East & $A$ & $03 / 13 / 90$ & 5377:01 & & Normal \\
\hline & & North & A & $03 / 13 / 90$ & 5377:03 & & Normal \\
\hline & & North & A & $03 / 19 / 90$ & & $5398: 01-17$ & Normal \\
\hline & & South & A & $03 / 13 / 90$ & 5377:02 & & Normal \\
\hline & & West & A & $04 / 06 / 90$ & 5432:01 & & Normal \\
\hline & & Center & 1 & $02 / 08 / 90$ & 5305:01-02 & & $\begin{array}{l}\text { Inspection revealed the } \\
\text { surface of the waste } \\
\text { below this riser was } \\
\text { liquid. Plans are to } \\
\text { install a reel tape at } \\
\text { this location. }\end{array}$ \\
\hline \multirow[t]{6}{*}{$F$} & 03 & East & A & $03 / 13 / 90$ & 5378:03 & & Normal \\
\hline & & North & A & $03 / 13 / 90$ & 5378:04 & & Normal \\
\hline & & South & A & $03 / 13 / 90$ & 5378:02 & & Normal \\
\hline & & South & A & $03 / 19 / 90$ & & $5407: 01-17$ & Normal \\
\hline & & Hest & A & $03 / 13 / 90$ & $5378: 01$ & & Normal \\
\hline & & 1 & I & $03 / 01 / 90$ & 5348:01-04 & & $\begin{array}{l}\text { Inspection was made to } \\
\text { determine if the absence } \\
\text { of liquid was the cause } \\
\text { of reel tape malfuni:- } \\
\text { tions. The surfacr: of } \\
\text { the waste was noc liquid. }\end{array}$ \\
\hline$F$ & 04 & East & A & $03 / 13 / 90$ & 5379:01 & & Normal \\
\hline $\mathrm{H}$ & 04 & North & A & $09 / 17 / 90$ & & $5650: 01-27$ & Normal \\
\hline \multirow[t]{3}{*}{$\mathbf{F}$} & 04 & South & $A$ & $03 / 19 / 90$ & & $5391: 01-17$ & Normal \\
\hline & & West & A & $03 / 13 / 90$ & 5379:02 & & Normal \\
\hline & & 1 & 1 & $06 / 27 / 90$ & $5551: 01-02$ & & $\begin{array}{l}\text { Inspection was made to } \\
\text { determine if the liquid } \\
\text { waste was covered by a } \\
\text { salt crust. No salt or } \\
\text { sol id waste was observed } \\
\text { on or above the super- } \\
\text { nate. }\end{array}$ \\
\hline \multirow[t]{5}{*}{$F$} & 05 & East & A & $03 / 23 / 90$ & 5399:01 & & Normal \\
\hline & & North & A. & $03 / 23 / 90$ & 5399:03 & & Noimal \\
\hline & & South & A & $03 / 23 / 90$ & 5399:02 & & Normal \\
\hline & & Hest & $A$ & $03 / 19 / 90$ & & $5392: 01-17$ & Normal \\
\hline & & 01 & 1 & $08 / 15 / 90$ & $5614: 01-02$ & & $\begin{array}{l}\text { Inspection was made to } \\
\text { determine if salt } \\
\text { deposits had formed on } \\
\text { the cool ing coils. No } \\
\text { significant salt buildup } \\
\text { was observed. }\end{array}$ \\
\hline
\end{tabular}

The numbers listed under WAP, DP, and PSP identify photographs in the UMT files.

WAP $=$ wide angle photography; $D P=$ direct photograpily; $P S P=$ pei iscopic photography;

$D B=$ diversion box; EVAP = evaporator; $C R C$ = cesiun removal column 
TABLE 1

SUMMARY OF INSPECTIONS

\begin{tabular}{|c|c|c|c|c|c|c|c|}
\hline \multirow[b]{2}{*}{ Area } & \multirow{2}{*}{$\begin{array}{c}\text { Tank } \\
\text { or } \\
\text { Vessel } \\
\end{array}$} & \multirow{2}{*}{$\begin{array}{l}\text { Inspec- } \\
\text { tion } \\
\text { Port } \\
\end{array}$} & \multirow{2}{*}{$\begin{array}{l}\text { Annulus } \\
\text { or } \\
\text { Interior }\end{array}$} & \multirow[b]{2}{*}{ Date } & \multicolumn{3}{|c|}{$\begin{array}{l}\text { Type of Inspection and } \\
\text { Ident ification Numbers }\end{array}$} \\
\hline & & & & & WAP & $D P$ & PSP \\
\hline \multirow[t]{5}{*}{$F$} & 06 & East & $A$ & $03 / 22 / 90$ & 5397:02 & & \\
\hline & & North & $A$ & $04 / 06 / 90$ & 5433:01 & & \\
\hline & & South & A & $03 / 19 / 90$ & & $5408: 01-17$ & \\
\hline & & West & A & $03 / 19 / 90$ & & $5412: 01-17$ & \\
\hline & & $\overline{02}$ & 1 & $08 / 15 / 90$ & 5615:01-02 & & \\
\hline
\end{tabular}

\section{determine if salt}

deposits had formed on the cooling coils. No significant salt buildup was observed.

\begin{tabular}{|c|c|c|c|c|c|c|}
\hline$F$ & 07 & North & A & $04 / 06 / 90$ & $5434: 01$ & Normal \\
\hline $\mathrm{H}$ & 07 & South & $A$ & $09 / 26 / 90$ & $5656: 01-17$ & Normal \\
\hline$F$ & 07 & Hest & A & $03 / 23 / 90$ & 5400:01 & Normal \\
\hline \multirow[t]{4}{*}{$F$} & 08 & East & A & $03 / 23 / 90$ & 5401:01 & Normal \\
\hline & & North & A & $03 / 19 / 90$ & 5393:01-17 & Normal \\
\hline & & South & A & $03 / 23 / 90$ & 5401:02 & Normal \\
\hline & & West & A & $03 / 19 / 90$ & $5411: 01-17$ & Normal \\
\hline \multirow[t]{7}{*}{$H$} & 09 & South & A & $01 / 04 / 90$ & $5213: 01-05$ & No change \\
\hline & & South & A & $01 / 12 / 90$ & 5216:01-07 & No change \\
\hline & & South & A & $01 / 17 / 90$ & $5241: 01-04$ & No change \\
\hline & & South & A & $01 / 25 / 90$ & 5268:01-06 & No change \\
\hline & & South & A & $01 / 31 / 90$ & 5275:01-07 & No change \\
\hline & & South & A & $02 / 07 / 90$ & 5298:01-04 & No change \\
\hline & & South & A & $02 / 13 / 90$ & $5306: 01-05$ & The surface of the dry \\
\hline
\end{tabular}

leaked waste had changed. The dry waste in the annulus is nominally 8-10 inches deep. A small void in the surface of the dry waste had developed adjacent to the primary vessel wall. It appeared that water had leaked into the annulus, dissolved, and relocated some of the waste.

\begin{tabular}{|c|c|c|c|c|}
\hline South & $A$ & $02 / 20 / 90$ & 5333:01-04 & No change \\
\hline South & A & $02 / 28 / 90$ & $5344: 01-07$ & No change \\
\hline South & A & $03 / 06 / 90$ & 5352:01-07 & No change \\
\hline South & A & $03 / 14 / 90$ & 5380:01-07 & No change \\
\hline South & $\mathbf{A}$ & $03 / 14 / 90$ & $5384: 01-29$ & $\begin{array}{l}\text { Inspection was made to } \\
\text { check the riser liner } \\
\text { and annulus adjacent to } \\
\text { the riser for a leak path } \\
\text { that allowed in or } \\
\text { groundwater to inter the } \\
\text { annulus. The riser liner }\end{array}$ \\
\hline
\end{tabular}


TABLE 1

SUMMARY OF INSPECTIONS

\begin{tabular}{|c|c|c|c|c|c|c|c|}
\hline \multirow[b]{2}{*}{ Area } & \multirow{2}{*}{$\begin{array}{c}\text { Tank } \\
\text { or } \\
\text { Vessel }\end{array}$} & \multirow{2}{*}{$\begin{array}{l}\text { Inspec- } \\
\text { tion } \\
\text { Port } \\
\end{array}$} & \multirow{2}{*}{$\begin{array}{l}\text { Annulus } \\
\text { or } \\
\text { Interior }\end{array}$} & \multirow[b]{2}{*}{ Date } & \multicolumn{3}{|c|}{$\begin{array}{l}\text { Type of Inspection and } \\
\text { Identification Numbers }\end{array}$} \\
\hline & & & & & HAP & $D P$ & PSP \\
\hline & 09 & South & $\wedge$ & $03 / 14 / 90$ & $5384: 01-29$ & & \\
\hline
\end{tabular}

Remarks

appeared to be in good condition. No leak path was found.

\begin{tabular}{lllll}
\hline South & $03 / 21 / 90$ & $5404: 01-06$ & The surface of the dry
\end{tabular}
waste in the annulus had changed slightly since 3-14-90.

South $A \quad 03 / 27 / 90 \quad 5414: 01-17$

The tank and annulus condition appeared unchanged since inspected on 8-5-88 except for the changes in the surface of the dry waste that have been documented by preceeding weekly inspec. tions.

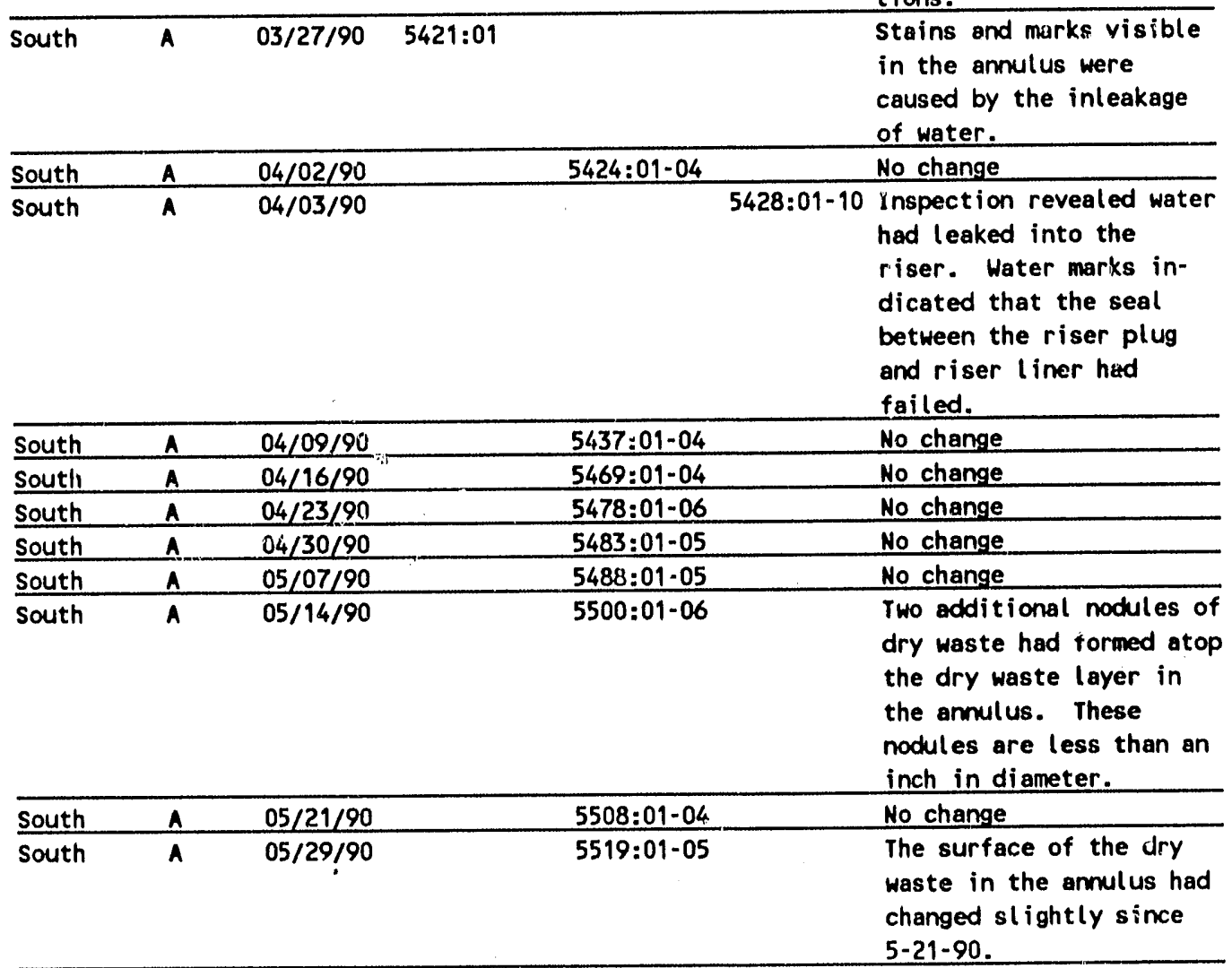


TABLE 1

SUMMARY OF INSPECTIONS

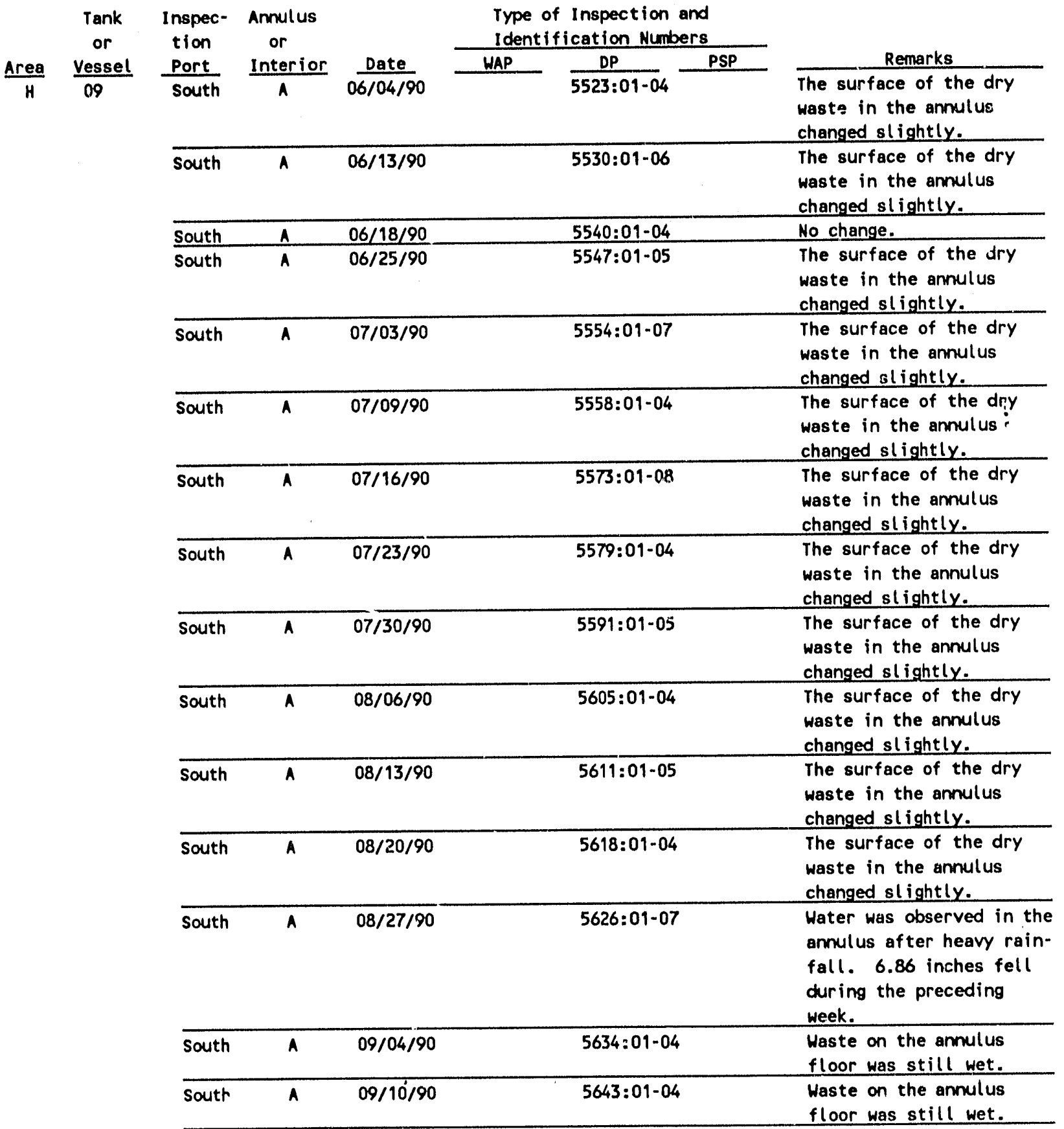


TABLE 1

SUMMARY OF INSPECTIONS

\begin{tabular}{|c|c|c|c|c|c|c|c|c|}
\hline \multirow{3}{*}{$\frac{\text { Area }}{H}$} & \multirow{3}{*}{$\begin{array}{c}\begin{array}{c}\text { Tank } \\
\text { or } \\
\text { Vessel }\end{array} \\
09\end{array}$} & \multirow{2}{*}{$\begin{array}{l}\text { Inspec- } \\
\text { tion } \\
\text { Port } \\
\end{array}$} & \multirow{2}{*}{$\begin{array}{l}\text { Annulus } \\
\text { or } \\
\text { Interior }\end{array}$} & \multirow[b]{2}{*}{ Date } & \multicolumn{3}{|c|}{$\begin{array}{l}\text { Type of Inspection and } \\
\text { Identification Numbers }\end{array}$} & \multirow[b]{2}{*}{ Remarks } \\
\hline & & & & & WAP & $D P$ & PSP & \\
\hline & & South & $A$ & $09 / 18 / 90$ & & $5647: 01-06$ & & $\begin{array}{l}\text { Waste on the anmulus } \\
\text { floor was still wet. }\end{array}$ \\
\hline & & South & $A$ & $09 / 24 / 90$ & & $5653: 01-06$ & & $\begin{array}{l}\text { Haste on the annulus } \\
\text { floor was still wet. }\end{array}$ \\
\hline & & South & $A$ & $10 / 03 / 90$ & & $5658: 01-04$ & & $\begin{array}{l}\text { Waste on the annulus } \\
\text { floor was still wet. }\end{array}$ \\
\hline & & South & $A$ & $10 / 08 / 90$ & & $5664: 01-0.4$ & & $\begin{array}{l}\text { Waste on the annulus } \\
\text { floor was still wet. }\end{array}$ \\
\hline & & South & $A$ & $10 / 16 / 90$ & & $5669: 01-04$ & & $\begin{array}{l}\text { Additional water was } \\
\text { observed in the annulus } \\
\text { after heavy rainfalls } \\
\text { totaling } 11.53 \text { inches } \\
\text { fell during the preceding } \\
\text { week. }\end{array}$ \\
\hline & & South & $A$ & $10 / 23 / 90$ & & $5675: 01-05$ & & $\begin{array}{l}\text { Waste on the annulus: } \\
\text { floor was still wet. }\end{array}$ \\
\hline & & South & $A$ & $10 / 29 / 90$ & & $5684: 01-04$ & & $\begin{array}{l}\text { Waste on the annulus } \\
\text { floor was still wet. }\end{array}$ \\
\hline & & South & A & $11 / 05 / 90$ & & $5689: 01-04$ & & $\begin{array}{l}\text { Waste on the annulus } \\
\text { floor was still wet. }\end{array}$ \\
\hline & & South & A & $11 / 12 / 90$ & & $5701: 01-05$ & & $\begin{array}{l}\text { Waste on the annulus } \\
\text { floor was still wet. }\end{array}$ \\
\hline & & South & $A$ & $11 / 19 / 90$ & & $5705: 01-04$ & & $\begin{array}{l}\text { Waste on the annulus } \\
\text { floor was still wet. }\end{array}$ \\
\hline & & South & $A$ & $11 / 26 / 90$ & & $5710: 01-04$ & & $\begin{array}{l}\text { Waste on the annulus } \\
\text { floor was still wet. }\end{array}$ \\
\hline & & South & $\mathbf{A}$ & $12 / 03 / 90$ & & $5716: 01-04$ & & $\begin{array}{l}\text { No rainwater was observed } \\
\text { in the annulus beneath } \\
\text { this riser. However, the } \\
\text { leaked waste on the } \\
\text { annulus floor appeared } \\
\text { to be damp. }\end{array}$ \\
\hline & & South & $A$ & $12 / 10 / 90$ & & $5721: 01-04$ & & $\begin{array}{l}\text { No rainwater was observed } \\
\text { in the annulus beneath } \\
\text { this riser. However, the } \\
\text { leaked waste on the } \\
\text { annulus floor appeared to } \\
\text { be damo. }\end{array}$ \\
\hline & & South & $A$ & $12 / 17 / 90$ & & $5726: 01-04$ & & $\begin{array}{l}\text { No rainwater was observed } \\
\text { in the annulus beneath } \\
\text { this riser. However, the } \\
\text { leaked waste on the } \\
\text { annu! us fluor appeared to } \\
\text { bs dam. }\end{array}$ \\
\hline
\end{tabular}


TABLE :

SUMMARY OF INSPECTIONS

\begin{tabular}{|c|c|c|c|c|c|c|c|}
\hline \multirow{2}{*}{ Irea } & \multirow{2}{*}{$\begin{array}{c}\text { Tank } \\
\text { or } \\
\text { Vessel }\end{array}$} & \multirow{2}{*}{$\begin{array}{l}\text { Inspec- } \\
\text { tion } \\
\text { Port } \\
\end{array}$} & \multirow{2}{*}{$\begin{array}{l}\text { Annulus } \\
\text { or } \\
\text { Interior }\end{array}$} & \multirow[b]{2}{*}{ Date } & \multicolumn{3}{|c|}{$\begin{array}{l}\text { Type of Inspection and } \\
\text { Identiticat' } n \text { Numbers }\end{array}$} \\
\hline & & & & & MAP & DP & PSP \\
\hline H & 09 & South & $A$ & $12 / 26 / 90$ & & $731: 01-04$ & \\
\hline
\end{tabular}

\begin{tabular}{llll}
\hline South & $A$ & $12 / 31 / 90$ & $5737: 01-04$ \\
\hline West & A & $01 / 04 / 90$ & $5215: 01-04$ \\
\hline West & A & $01 / 12 / 90$ & $5217: 01-05$ \\
\hline Uest & A & $01 / 17 / 90$ & $5240: 01-04$ \\
\hline West & A & $01 / 25 / 90$ & $5269: 01-06$
\end{tabular}

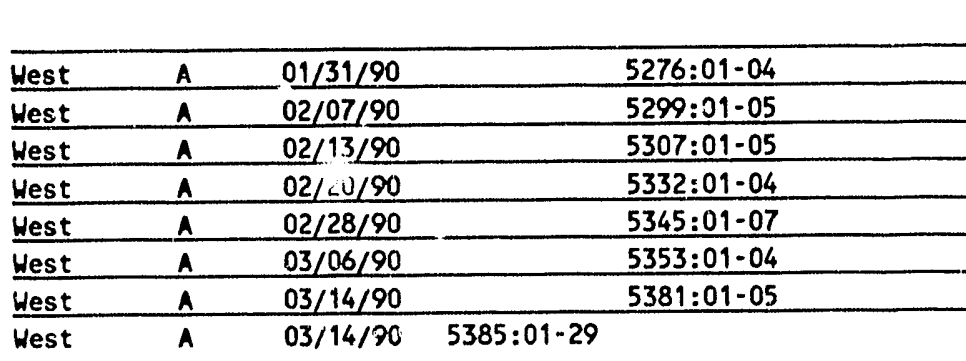


TABLE 1

SUMMARY OF INSPECTIONS

$\begin{array}{ccc}\begin{array}{c}\text { Tank } \\ \text { or } \\ \text { Area }\end{array} \frac{\begin{array}{c}\text { Inspec- Annulus } \\ \text { tion } \\ \text { Vessel }\end{array}}{\text { Port }} & \begin{array}{c}\text { Interior } \\ \text { Hest }\end{array} & \frac{\text { Date }}{04 / 03 / .0}\end{array}$

West A 04/04/90

Type of Inspection and

Identification Numbers

WAP $-D P \quad \frac{P S P}{5429: 01-0}$
Remarks

and riser liner had failed.

5430:01-08 Two leaksites were observed high on the tank wall. The cracks were estimated to be 271 and 276 inches above the tank bottom. Both cracks were on a vertical plate weld in the top knuckle plate course. The leaksites were evident because of small deposits of leaked waste on the tank exterior. These obviously: are old leaksites since the tank content has not been as high as the cracks since 1960.

\begin{tabular}{llll}
\hline Hest & A & $04 / 09 / 90$ & $5438: 01-04$ \\
\hline Hest & A & $04 / 16 / 90$ & $5470: 04-04$ \\
\hline Hest & $A$ & $04 / 23 / 90$ & $5479: 01-04$ \\
\hline Hest & $A$ & $04 / 30 / 90$ & $5484: 01-04$ \\
\hline Hest & A & $05 / 07 / 90$ & $5489: 01$ \\
\hline Hest & A & $05 / 14 / 90$ & $5501: 01-06$
\end{tabular}
No change No change No change No change No change The surface of the dry waste in the annulus changed slightly.

\begin{tabular}{lllll}
\hline West & A & $05 / 21 / 90$ & $5509: 01-04$ & No change \\
\hline Hest & A & $05 / 29 / 90$ & $5518: 01-04$ & No change \\
\hline Hest & A & $06 / 04 / 90$ & $5524: 01-04$ & No change \\
\hline Hest & A & $06 / 13 / 90$ & $5529: 01-05$ & No change \\
\hline Hest & A & $06 / 18 / 90$ & $5539: 01-04$ & No change \\
\hline Hest & A & $06 / 25 / 90$ & $5546: 01-05$ & No change \\
\hline West & A & $07 / 03 / 90$ & $5553: 01-04$ & No change \\
\hline Hest & A & $07 / 09 / 90$ & $5557: 01-04$ & No change \\
\hline Hest & A & $07 / 16 / 90$ & $5572: 01-08$ & No change \\
\hline West & A & $07 / 23 / 90$ & $5578: 01-04$ & $\begin{array}{l}\text { The surface of the dry } \\
\text { waste in the annulus } \\
\text { changed slightly. }\end{array}$ \\
\hline West & A & $07 / 30 / 90$ & & $\begin{array}{l}\text { The surface of the dry } \\
\text { waste in the annulus } \\
\text { changed slightly. }\end{array}$ \\
\hline Hest & A & $08 / 06 / 90$ & $5590: 01-05$ & No change
\end{tabular}


TABLE 1

SUMMARY OF INSPECTIONS

\begin{tabular}{|c|c|c|c|c|c|c|c|c|}
\hline \multirow{3}{*}{$\frac{\text { Area }}{H}$} & \multirow{3}{*}{$\begin{array}{c}\text { Tank } \\
\text { or } \\
\text { Vessel }\end{array}$} & \multirow{2}{*}{$\begin{array}{l}\text { Inspec- } \\
\text { tion } \\
\text { Port } \\
\end{array}$} & \multirow{2}{*}{$\begin{array}{l}\text { Annulus } \\
\text { or } \\
\text { Interior }\end{array}$} & \multirow[b]{2}{*}{ Date } & \multicolumn{3}{|c|}{$\begin{array}{l}\text { Type of Inspection and } \\
\text { Identification Numbers }\end{array}$} & \multirow[b]{2}{*}{ Remarks } \\
\hline & & & & & MAP & DP & PSP & \\
\hline & & West & $A$ & $08 / 18 / 90$ & & $5610: 01-04$ & & No change \\
\hline & & West & A & $08 / 20 / 90$ & & $5617: 01-05$ & & No change \\
\hline & & Hest & A & $08 / 27 / 90$ & & $5625: 01-06$ & & $\begin{array}{l}\text { Water was observed in the } \\
\text { annulus after heavy rain- } \\
\text { fall. } 6.86 \text { inches fell } \\
\text { during the preceding } \\
\text { week. }\end{array}$ \\
\hline & & West & A & $09 / 04 / 90$ & & $5633: 01-04$ & & $\begin{array}{l}\text { Waste on the annulus } \\
\text { floor was still wet. }\end{array}$ \\
\hline & & West & A & $09 / 10 / 90$ & & $5642: 01-04$ & & $\begin{array}{l}\text { Waste on the annulus } \\
\text { floor was still wet. }\end{array}$ \\
\hline & & West & A & $09 / 18 / 90$ & & $5646: 01-05$ & & $\begin{array}{l}\text { Waste on the anmulus } \\
\text { floor was still wet. The } \\
\text { conduct ivity probe was } \\
\text { not properly positioned. }\end{array}$ \\
\hline & & Hest & A & $09 / 24 / 90$ & & $5652: 01-06$ & & $\begin{array}{l}\text { Waste on the annulus } \\
\text { floor was still wet. The } \\
\text { conductivity probe was } \\
\text { not properly positioned. } \\
\text { on the annulus floor. } \\
\text { The thermocouple that is } \\
\text { to be magnetically mount- } \\
\text { ed on the tank wall was } \\
\text { not contacting the wall. }\end{array}$ \\
\hline & & West & A & $10 / 03 / 90$ & & $5657: 01-05$ & & $\begin{array}{l}\text { Waste on the annulus } \\
\text { floor was still wet. The } \\
\text { conduct ivity probe was } \\
\text { not properly positioned } \\
\text { on the annulus floor. } \\
\text { The thermocouple was } \\
\text { properly positioned on } \\
\text { the tank wa!i. }\end{array}$ \\
\hline & & West & $\lambda$ & $10 / 08 / 90$ & & $5663: 01-04$ & & $\begin{array}{l}\text { Waste on the annulus } \\
\text { floor was still vet. The } \\
\text { conductivity probe was } \\
\text { not properly positioned } \\
\text { on the annulus floor. }\end{array}$ \\
\hline & & Hest & A & $10 / 16,90$ & & $5668: 01-05$ & & $\begin{array}{l}\text { Additional we er was } \\
\text { observed in the annulus } \\
\text { after heavy rainfalls } \\
\text { totaling } 11.53 \text { inches } \\
\text { fell during the preceding } \\
\text { week. The conductivity } \\
\text { probe was properly } \\
\text { positioned in the } \\
\text { annulus. }\end{array}$ \\
\hline
\end{tabular}


TABLE 1

SUMMARY OF INSPECTIONS

\begin{tabular}{|c|c|c|c|c|c|c|c|}
\hline \multirow[b]{2}{*}{ A,ea } & \multirow{2}{*}{$\begin{array}{c}\text { Tank } \\
\text { or } \\
\text { Vessel } \\
\end{array}$} & \multirow{2}{*}{$\begin{array}{l}\text { Inspec- } \\
\text { tion } \\
\text { Port } \\
\end{array}$} & \multirow{2}{*}{$\begin{array}{l}\text { Annulus } \\
\text { or } \\
\text { Interior }\end{array}$} & \multirow[b]{2}{*}{ Date } & \multicolumn{2}{|c|}{$\begin{array}{l}\text { Type of Inspection and } \\
\text { Ident ification Numbers }\end{array}$} & \multirow[b]{2}{*}{ Remarks } \\
\hline & & & & & HAP & $D P \quad P S P$ & \\
\hline \multirow[t]{12}{*}{$H$} & & West & $A$ & $10 / 23 / 90$ & & $\overline{5674: 01-07}$ & $\begin{array}{l}\text { Haste on the anmulus } \\
\text { floor was still wet. }\end{array}$ \\
\hline & & West & $A$ & $10 / 29 / 90$ & & 5683:01-04 & $\begin{array}{l}\text { Waste on the annulus } \\
\text { floor was still wet. }\end{array}$ \\
\hline & & West & $A$ & $11 / 05 / 90$ & & $5688: 01-06$ & $\begin{array}{l}\text { Haste on the annulus } \\
\text { floor was still wet. }\end{array}$ \\
\hline & & West & A & $11 / 12 / 90$ & & $5700: 01-05$ & $\begin{array}{l}\text { Haste on the annulus } \\
\text { floor was still wet. }\end{array}$ \\
\hline & & West & A & $11 / 19 / 90$ & & $5704: 01-04$ & $\begin{array}{l}\text { Waste on the armulus } \\
\text { floor was still wet. }\end{array}$ \\
\hline & & West & $A$ & $11 / 26 / 90$ & & 5709:01-04 & $\begin{array}{l}\text { Waste on the anmulus } \\
\text { floor was still wet. }\end{array}$ \\
\hline & & West & A & $12 / 03 / 90$ & & 5715:01-04 & $\begin{array}{l}\text { No rainwater was observed } \\
\text { in the annulus beneath } \\
\text { this riser. However, the } \\
\text { leaked waste on the } \\
\text { annulus floor appeared to } \\
\text { be damp. }\end{array}$ \\
\hline & & West & $A$ & $12 / 10 / 90$ & & $5720: 02-04$ & $\begin{array}{l}\text { No rainwater was observed } \\
\text { in the annulus beneath } \\
\text { this riser. However, the } \\
\text { leaked waste on the } \\
\text { annulus floor appeared to } \\
\text { be damp. }\end{array}$ \\
\hline & & West & A & $12 / 17 / 90$ & & $5725: 01-04$ & $\begin{array}{l}\text { No rainwater was observed } \\
\text { in the annulus beneath } \\
\text { this riser. However, the } \\
\text { leaked waste on the } \\
\text { annulus floor appeared to } \\
\text { be damp. }\end{array}$ \\
\hline & & West & A & $12 / 26 / 90$ & & $5730: 01-05$ & $\begin{array}{l}\text { No rainwater was observed } \\
\text { in the annulus beneath } \\
\text { this riser. However, the } \\
\text { leaked waste on the } \\
\text { annulus floor appeared to } \\
\text { be damp. }\end{array}$ \\
\hline & & Hest & A & $12 / 31 / 90$ & & $5736: 01-05$ & $\begin{array}{l}\text { The annulus appeared to } \\
\text { be dry. }\end{array}$ \\
\hline & & 05 & 1 & $03 / 15 / 90$ & $5386: 01-02$ & & $\begin{array}{l}\text { Inspection was made to } \\
\text { determine if the absence } \\
\text { of liquid was the cause } \\
\text { of reel tape nalfunc- } \\
\text { tions. The surface of } \\
\text { the waste was not liquid. }\end{array}$ \\
\hline
\end{tabular}


TABLE 1

SUMMARY OF INSPECTIONS

\begin{tabular}{|c|c|c|c|c|c|c|c|}
\hline \multirow{2}{*}{ Area } & \multirow{2}{*}{$\begin{array}{l}\text { Tani } \\
\text { or } \\
\text { Vessel }\end{array}$} & \multirow{2}{*}{$\begin{array}{l}\text { Inspec- } \\
\text { tion } \\
\text { Port }\end{array}$} & \multirow{2}{*}{$\begin{array}{l}\text { Annulus } \\
\text { or } \\
\text { Interior }\end{array}$} & \multirow[b]{2}{*}{ Date } & \multicolumn{3}{|c|}{$\begin{array}{l}\text { Type of Inspection and } \\
\text { Identification Numbers }\end{array}$} \\
\hline & & & & & MAP & DP & PSP \\
\hline $\bar{H}$ & $\overline{10}$ & East & $A$ & $04 / 02 / 90$ & $5422: 01$ & & \\
\hline
\end{tabular}

\begin{tabular}{llll}
\hline North & A & $01 / 04 / 90$ & $5212: 01-0$ \\
\hline North & A & $01 / 12 / 90$ & $5218: 01-04$ \\
\hline North & A & $01 / 17 / 90$ & $5243: 01-0$ \\
\hline North & A & $01 / 25 / 90$ & $5270: 01-0$ \\
\hline North & A & $01 / 31 / 90$ & $5277: 01-04$ \\
\hline North & A & $02 / 07 / 90$ & $5300: 01-0$ \\
\hline North & A & $02 / 13 / 90$ & $5309: 01-0$ \\
\hline North & A & $02 / 20 / 90$ & $5335: 01-0$ \\
\hline North & A & $02 / 28 / 90$ & $5346: 01-04$ \\
\hline North & A & $03 / 06 / 90$ & $5354: 01-06$ \\
\hline North & A & $03 / 14 / 90$ & $5382: 01-06$ \\
\hline North & A & $03 / 21 / 90$ & $5406: 01-04$ \\
\hline North & A & $03 / 27 / 90$ & $5418: 01-17$
\end{tabular}

Remarks

Stains and marks visible

in the annulus were caused by the inleakage of water. No change No change No change No change No change No change No change No change No change No change No change No change The tank and annulus condition appeared unchanged since inspected on 4-4-89 except for the changes in the surface of the dry waste that have been documented by preceeding weekly inspections.

\begin{tabular}{lllll}
\hline North & A & $04 / 02 / 90$ & $5426: 01-04$ & No change \\
\hline North & A & $04 / 09 / 90$ & $5439: 01-04$ & No change \\
\hline North & A & $04 / 16 / 90$ & $5471: 01-04$ & No change \\
\hline North & A & $04 / 23 / 90$ & $5480: 01-04$ & No change \\
\hline North & A & $04 / 30 / 90$ & $5485: 01-04$ & No change \\
\hline North & A & $05 / 07 / 90$ & $5490: 01-04$ & No change \\
\hline North & A & $05 / 14 / 90$ & $5502: 01-04$ & No change \\
\hline North & A & $05 / 21 / 90$ & $5510: 01-05$ & No change \\
\hline North & A & $05 / 29 / 90$ & $5520: 01-04$ & No change \\
\hline North & A & $06 / 04 / 90$ & $5525: 01-04$ & No change \\
\hline North & A & $06 / 13 / 90$ & $5532: 01-04$ & No change \\
\hline North & A & $06 / 18 / 90$ & $5542: 01-04$ & No change \\
\hline North & A & $06 / 25 / 90$ & $5549: 01-04$ & No change \\
\hline North & A & $07 / 03 / 90$ & $5556: 01-04$ & No change \\
\hline North & A & $07 / 09 / 90$ & $5560: 01-04$ & No change \\
\hline North & A & $07 / 16 / 90$ & $5575: 01-05$ & No change \\
\hline North & A & $07 / 23 / 90$ & $5581: 01-04$ & No change \\
\hline North & A & $07 / 30 / 90$ & $5593: 01-04$ & No change \\
\hline
\end{tabular}


TABLE 1

SUMAARY OF INSPECTIONS

\begin{tabular}{|c|c|c|c|c|c|c|c|}
\hline \multirow[b]{2}{*}{ Area } & \multirow{2}{*}{$\begin{array}{c}\text { Tank } \\
\text { or } \\
\text { Vessel } \\
\end{array}$} & \multirow{2}{*}{$\begin{array}{c}\text { Inspec- } \\
\text { tion } \\
\text { Port } \\
\end{array}$} & \multirow{2}{*}{$\begin{array}{l}\text { Annulus } \\
\text { or } \\
\text { Interior }\end{array}$} & \multirow[b]{2}{*}{ Date } & \multicolumn{2}{|c|}{$\begin{array}{l}\text { Type of Inspection and } \\
\text { Identification Numbers }\end{array}$} & \multirow[b]{2}{*}{ Remarks } \\
\hline & & & & & MAP & $D P \quad P S P$ & \\
\hline & 10 & North & $A$ & $08 / 06 / 90$ & & 5607:01-04 & No change \\
\hline & & North & $A$ & $08 / 13 / 90$ & & $5613: 01-04$ & No change \\
\hline & & North & $A$ & $08 / 20 / 90$ & & $5620: 01-04$ & Ho change \\
\hline & & worth & $A$ & $08 / 27 / 90$ & & $5628: 01-04$ & $\begin{array}{l}\text { Water was observed in the } \\
\text { annulus after heavy rain- } \\
\text { fall. } 6.86 \text { inches fell } \\
\text { during the preceding } \\
\text { week. }\end{array}$ \\
\hline & & North & A & $09 / 04 / 90$ & & $5636: 01-04$ & $\begin{array}{l}\text { Waste on the ennulus } \\
\text { floor was still wet. }\end{array}$ \\
\hline & & North & A & $09 / 10 / 90$ & & $5645: 01-04$ & $\begin{array}{l}\text { Waste on the ariulus } \\
\text { floor was still wet. }\end{array}$ \\
\hline & & North & A & $09 / 18 / 90$ & & $5649: 01-04$ & $\begin{array}{l}\text { The water on the annulus } \\
\text { floor had evaporated. }\end{array}$ \\
\hline & & North & A & $09 / 24 / 90$ & & $5655: 01-04$ & $\begin{array}{l}\text { A few of the nodules of } \\
\text { dry waste that formed as } \\
\text { the weter evaporated had } \\
\text { increased slightly in } \\
\text { size. }\end{array}$ \\
\hline & & North & A & $10 / 03 / 90$ & & $5660: 01-04$ & No change \\
\hline & & North & A & $10 / 08 / 90$ & & 5666:01-04 & No change \\
\hline & & North & A & $10 / 16 / 90$ & & $5671: 01-04$ & $\begin{array}{l}\text { No rainfall was observed } \\
\text { in the annulus beneath } \\
\text { this riser. However, the } \\
\text { leaked waste on the } \\
\text { annulus floor appeared to } \\
\text { be damp. }\end{array}$ \\
\hline & & North & A & $10 / 23 / 90$ & & $5677: 01-04$ & $\begin{array}{l}\text { An area of the annulus } \\
\text { pan wall above the leaked } \\
\text { waste on the annulus } \\
\text { floor was damp. This } \\
\text { indicates that rainwater } \\
\text { leaked into the annulus } \\
\text { and wetted the wante } \\
\text { beneath this riser. }\end{array}$ \\
\hline & & North & $A$ & $10 / 29 / 90$ & & $5686: 01-04$ & $\begin{array}{l}\text { The anmulus floor appear - } \\
\text { ed dr:. }\end{array}$ \\
\hline & & North & A & $11 / 05 / 90$ & & $5691: 01-04$ & $\begin{array}{l}\text { The surface of the leaked } \\
\text { waste had changed. It } \\
\text { appeared the rainwater } \\
\text { that had leaked into the } \\
\text { annulus during the week } \\
\text { of } 10-8-90 \text { dissolved and } \\
\text { relocated some of the } \\
\text { waste. }\end{array}$ \\
\hline
\end{tabular}


TABLE 1

SUMMARY OF INSPECTIONS

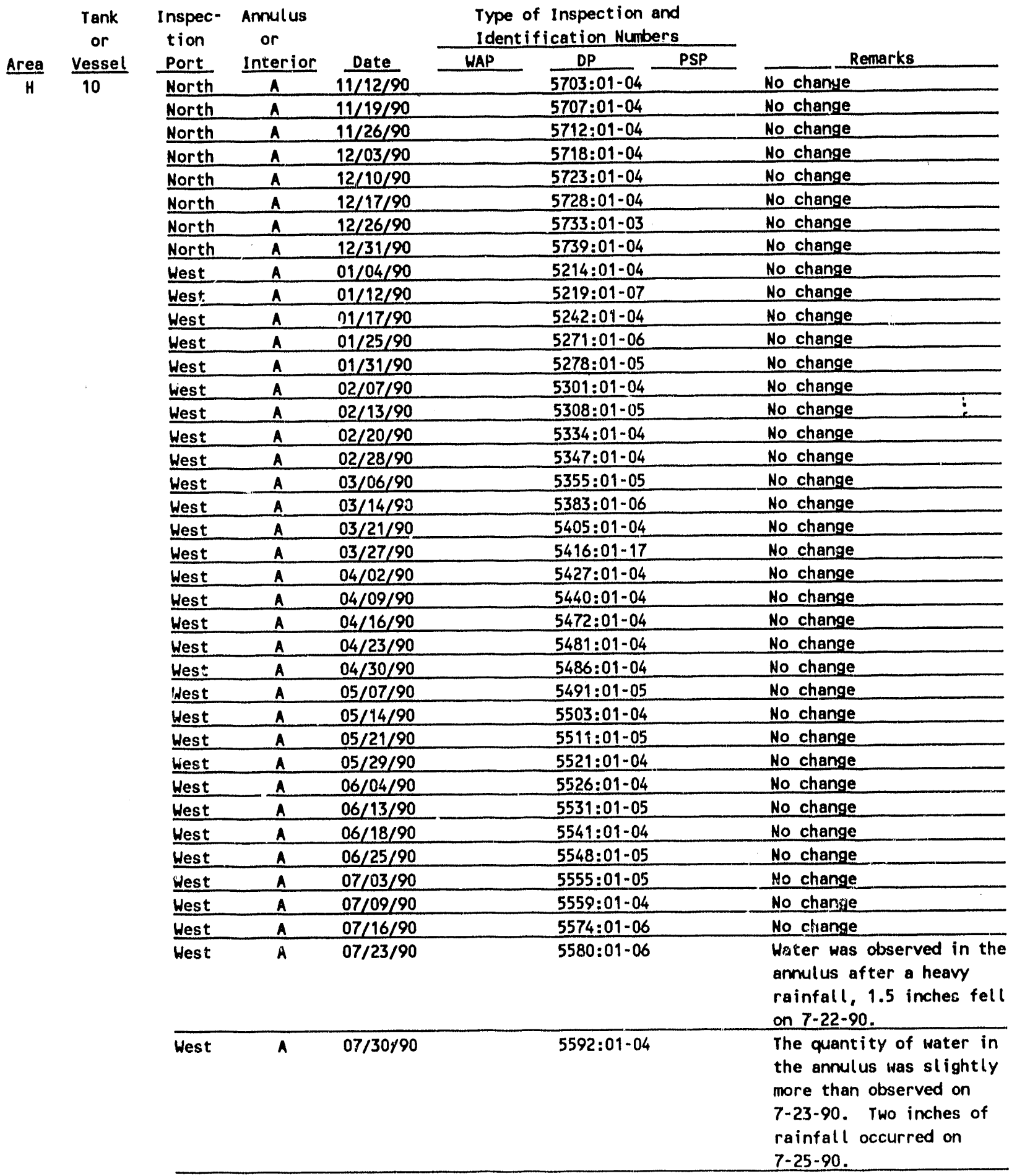


TABLE 1

SUMMARY OF INSPECTIONS

\begin{tabular}{|c|c|c|c|c|c|c|c|}
\hline \multirow[b]{2}{*}{ Area } & \multirow{2}{*}{$\begin{array}{c}\text { Tank } \\
\text { or } \\
\text { Vessel }\end{array}$} & \multirow{2}{*}{$\begin{array}{l}\text { Inspec- } \\
\text { tion } \\
\text { Port } \\
\end{array}$} & \multirow{2}{*}{$\begin{array}{l}\text { Anmulus } \\
\text { or } \\
\text { Interior }\end{array}$} & \multirow[b]{2}{*}{ Date } & \multicolumn{3}{|c|}{$\begin{array}{l}\text { Type of Inspection and } \\
\text { Identification Numbers }\end{array}$} \\
\hline & & & & & WAP & DP & PSP \\
\hline $\bar{H}$ & 10 & West & $A$ & $08 / 06 / 90$ & & $5605: 01-04$ & \\
\hline
\end{tabular}

Remarks Approximately half of the water that was observed in the onnulus on 7-30 had evaporated.

\begin{tabular}{llll}
\hline West & $A$ & $08 / 13 / 90$ & $5612: 01-04$ \\
& & \\
\hline Hest & $A$ & $08 / 20 / 90$ & $5619: 01-04$ \\
\hline Hest & $A$ & $08 / 27 / 90$ & $5627: 01-04$
\end{tabular}
No change was observed in the tank condition. The annulus was essentially dry. No change Water was observed in the annulus after heavy rainfall. 6.86 inches fell during the preceding week.

\begin{tabular}{|c|c|c|c|c|}
\hline West & $A$ & $09 / 04 / 90$ & $5635: 01-04$ & $\begin{array}{l}\text { Waste on the anmulus: } \\
\text { floor was still wet. }\end{array}$ \\
\hline West & A & $09 / 10 / 90$ & $5644: 01-04$ & $\begin{array}{l}\text { Waste on the annulus } \\
\text { floor was still wet. }\end{array}$ \\
\hline West & A & $09 / 18 / 90$ & $5648: 01-04$ & $\begin{array}{l}\text { Waste on the annulus } \\
\text { floor was still wet. }\end{array}$ \\
\hline West & A & $09 / 24 / 90$ & $5654: 01-04$ & $\begin{array}{l}\text { The water on the anmulus } \\
\text { floor had evaporated. }\end{array}$ \\
\hline West. & A & $10 / 03 / 90$ & 5659:01-04 & No change. \\
\hline West & A & $10 / 08 / 90$ & $5665: 01-04$ & No change. \\
\hline West & $\frac{n}{A}$ & $10 / 16 / 90$ & $5670: 01-04$ & $\begin{array}{l}\text { Additional water was } \\
\text { observed in the annulus }\end{array}$ \\
\hline
\end{tabular}
after heavy rainfalls totaling 11.53 inches fell during the preceding week.

\begin{tabular}{lllll}
\hline Hest & A & $10 / 23 / 90$ & $5676: 01-05$ & $\begin{array}{l}\text { Waste on the anmulus } \\
\text { floor was still wet. }\end{array}$ \\
\hline West & A & $10 / 29 / 90$ & $5685: 01-04$ & $\begin{array}{l}\text { Waste on the anmulus } \\
\text { floor was still wet. }\end{array}$ \\
\hline West & A & $11 / 05 / 90$ & $5690: 01-04$ & $\begin{array}{l}\text { The annulus floor was } \\
\text { still damp from inleakage } \\
\text { of rainwater the week of } \\
10-8-90 .\end{array}$ \\
\hline Hest & A & $11 / 12 / 90$ & $\begin{array}{l}\text { The waste on the annulus } \\
\text { floor appeared to be dry. }\end{array}$ \\
\hline Hest & A & $11 / 19 / 90$ & $5702: 01-04$ & No change \\
\hline West & A & $11 / 26 / 90$ & $5706: 01-04$ & No change \\
\hline Hest & A & $12 / 03 / 90$ & $5711: 01-04$ & No change \\
\hline
\end{tabular}


TABLE 1

SUMMARY OF INSPECTIONS

\begin{tabular}{|c|c|c|c|c|c|c|c|}
\hline \multirow{3}{*}{$\frac{\text { Area }}{H}$} & \multirow{3}{*}{$\begin{array}{l}\text { Tank } \\
\text { or } \\
\text { Vessel }\end{array}$} & \multirow{2}{*}{$\begin{array}{l}\text { Inspec- } \\
\text { tion } \\
\text { Port } \\
\end{array}$} & \multirow{2}{*}{$\begin{array}{l}\text { Annulus } \\
\text { or } \\
\text { Interior }\end{array}$} & \multirow[b]{2}{*}{ Date } & \multicolumn{2}{|c|}{$\begin{array}{l}\text { Type of Inspection and } \\
\text { Ident if ication Numbers }\end{array}$} & \multirow[b]{2}{*}{ Remarks } \\
\hline & & & & & WAP & $D P \quad P S P$ & \\
\hline & & Hest & $A$ & $12 / 10 / 90$ & & 5722:01-04 & No change \\
\hline & & West & A & $12 / 17 / 90$ & & 5727:01-04 & No change \\
\hline & & West & A & $12 / 26 / 90$ & & $5732: 01-04$ & No change \\
\hline & & West & $A$ & $12 / 31 / 90$ & & 5738:01-04 & No change \\
\hline & & 01 & 1 & $03 / 15 / 90$ & $5387: 01-03$ & & $\begin{array}{l}\text { No liquid was observed. } \\
\text { A crust of salt crystals } \\
\text { covered the supernate. }\end{array}$ \\
\hline \multirow[t]{5}{*}{$H$} & 11 & East & A & $03 / 27 / 90$ & & 5420:01-17 & No change \\
\hline & & North & A & $03 / 27 / 90$ & & $5419: 01-17$ & No change \\
\hline & & South & A & $07 / 30 / 90$ & $5594: 04$ & & No change \\
\hline & & West & A & $03 / 27 / 90$ & 5409:01 & & No change \\
\hline & & 06 & 1 & $07 / 30 / 90$ & $5595: 01$ & & $\begin{array}{l}\text { Inspection was made to } \\
\text { determine if salt } \\
\text { deposits had accumulated } \\
\text { on the cooling coils. } \\
\text { Very little salt was } \\
\text { desposited on the coils. }\end{array}$ \\
\hline \multirow[t]{4}{*}{ H } & 12 & East & A & $03 / 27 / 90$ & $5410: 02$ & & No change \\
\hline & & North & A & $03 / 27 / 90$ & & $5417: 01-17$ & No change \\
\hline & & South & A & $03 / 27 / 90$ & $5410: 01$ & & No change \\
\hline & & West & A & $03 / 27 / 90$ & & $5413: 01-17$ & No change \\
\hline \multirow[t]{14}{*}{ H } & 13 & 010 & A & $04 / 12 / 90$ & & 5465:01-17 & No change \\
\hline & & 032 & A & $04 / 12 / 90$ & & 5466:01-17 & No change \\
\hline & & 055 & A & $04 / 12 / 90$ & & $5467: 01-17$ & No change \\
\hline & & 071 & A & $04 / 12 / 90$ & & $5468: 01-17$ & No change \\
\hline & & 107 & A & $04 / 12 / 90$ & 5460:05 & & No change \\
\hline & & 151 & A & $04 / 12 / 90$ & & 5463:01-17 & No change \\
\hline & & 175 & A & $04 / 12 / 90$ & $5460: 02$ & & No change \\
\hline & & $\underline{207}$ & A & $04 / 12 / 90$ & $5460: 04$ & & No change \\
\hline & & $\underline{228}$ & A & $04 / 12 / 90$ & & $5464: 01-17$ & No change \\
\hline & & East & $A$ & $04 / 12 / 90$ & $5460: 03$ & & No change \\
\hline & & Nortin & $\wedge$ & $04 / 12 / 90$ & & $5461: 01-17$ & $\begin{array}{l}\text { Stains and marks visible } \\
\text { in the annulus were } \\
\text { caused by the inleakage } \\
\text { of water. }\end{array}$ \\
\hline & & South & $A$ & $04 / 12 / 90$ & & 5462:01-17 & No change \\
\hline & & West & A & $04 / 12 / 90$ & 5460:01 & & No change \\
\hline & & $04 A$ & 1 & $06 / 12 / 90$ & $5528: 01$ & & $\begin{array}{l}\text { Inspection was made to } \\
\text { determine if salt } \\
\text { deposits had formed on } \\
\text { the cooling coils. No } \\
\text { significant salt buildup } \\
\text { was observed. }\end{array}$ \\
\hline
\end{tabular}


TABLE 1

SUMMARY OF INSPECTIONS

$\begin{array}{cccc}\begin{array}{c}\text { Tank Inspec- Annulus } \\ \text { or }\end{array} & \begin{array}{c}\text { Tyon of Inspection and } \\ \text { tion }\end{array} & \begin{array}{c}\text { Type or } \\ \text { Identification Numbers }\end{array} \\ \frac{\text { Area }}{H} & \frac{\text { Vessel }}{14} & \frac{\text { Port }}{\text { South }} & \text { Interior } \frac{\text { Date }}{05 / 04 / 90}\end{array}$

Remarks

CCTV was used to inspect the annulus and verified that adequate clearance existed between the wall and the duct for install. ing the new replacement jet. No change

\begin{tabular}{lllll}
\hline 013 & $A$ & $04 / 10 / 90$ & $5441: 08$ & \\
\hline 013 & $A$ & $07 / 11 / 90$ & & $5570: 01-05$
\end{tabular}

Inspection was made to determine if any change in anmulus conditions had occurred during the 6 weeks the ventilation fan was out of service. No change had occurred. :

\begin{tabular}{|c|c|c|c|c|}
\hline 032 & A & $04 / 10 / 90$ & 5441:09 & No change \\
\hline 065 & A & $04 / 10 / 90$ & 5442:01-17 & No change. \\
\hline 065 & A & $07 / 11 / 90$ & $5561: 01-05$ & Inspection was made to \\
\hline
\end{tabular}
determine if any change in annulus conditions had occurred during the 6 weeks the ventilation fan was out of service. No change had occurred.

\begin{tabular}{lllll}
\hline 108 & A & $04 / 10 / 90$ & $5436: 01-17$ & No change \\
\hline 108 & A & $07 / 11 / 90$ & $5562: 01-05$ & $\begin{array}{l}\text { Inspection was made to } \\
\text { determine if any change }\end{array}$
\end{tabular}
in annulus conditions had oscurred during the 6 weeks the ventialtion fan was out of service. No change had occurred.

\begin{tabular}{llll}
\hline 118 & $A$ & $04 / 10 / 90$ & $5443: 01-17$ \\
\hline 118 & $A$ & $07 / 11 / 90$ & $5563: 01-05$
\end{tabular}

No change

Inspection was made to determine if any change in anmulus conditions had occurred during the 6 weeks the ventilation fan was out of service. No change had occurred.

\begin{tabular}{|c|c|c|c|c|}
\hline 125 & A & $04 / 10 / 90$ & 5444:01-17 & No change \\
\hline 125 & $A$ & $07 / 11 / 90$ & $5564: 01-05$ & $\begin{array}{l}\text { Inspection was made to } \\
\text { determine if any change } \\
\text { in anmulus conditions had } \\
\text { occurred during the } 6 \\
\text { weeks the ventilation fan } \\
\text { was out of service. No }\end{array}$ \\
\hline
\end{tabular}


TABLE 1

SUMMARY OF INSPECTIONS

\begin{tabular}{|c|c|c|c|c|c|c|c|}
\hline \multirow{3}{*}{$\frac{\text { Area }}{H}$} & \multirow{3}{*}{$\begin{array}{c}\text { Tank } \\
\text { or } \\
\text { Vessel }\end{array}$} & \multirow{2}{*}{$\begin{array}{l}\text { Inspec- } \\
\text { tion } \\
\text { Port } \\
\end{array}$} & \multirow{2}{*}{$\begin{array}{l}\text { Annulus } \\
\text { or } \\
\text { Interior }\end{array}$} & \multirow[b]{2}{*}{ Date } & \multicolumn{2}{|c|}{$\begin{array}{l}\text { Type of Inspection and } \\
\text { Identification Numbers }\end{array}$} & \multirow[b]{2}{*}{ Remarks } \\
\hline & & & & & MAP & $D P \quad P S P$ & \\
\hline & & 125 & $A$ & $07 / 11 / 90$ & & $5564: 01-05$ & change had occurred. \\
\hline & & 151 & A & $04 / 10 / 90$ & $5441: 02$ & & No change \\
\hline & & 151 & A & $07 / 11 / 90$ & & $5585: 01-05$ & $\begin{array}{l}\text { Inspection was made to } \\
\text { determine if any change } \\
\text { in anmulus conditions had } \\
\text { occurred during the } 6 \\
\text { weeks the ventilation fan } \\
\text { was out of service. No } \\
\text { change had occurred. }\end{array}$ \\
\hline & & 170 & A & $04 / 10 / 90$ & $5441: 03$ & & $\begin{array}{l}\text { Stains and marks visible } \\
\text { in the anmulus were caus- } \\
\text { ed by the inleakage of } \\
\text { water. }\end{array}$ \\
\hline & & 170 & A & $07 / 11 / 90$ & & $5566: 01-05$ & $\begin{array}{l}\text { Inspection was made to } \\
\text { determine if any change } \\
\text { in annulus conditions had } \\
\text { occurred during the } 6 \\
\text { weeks the ventilation fan } \\
\text { was out of service. No } \\
\text { chainge had occurred. }\end{array}$ \\
\hline & & 207 & A. & $04 / 10 / 90$ & $5441: 05$ & & No change \\
\hline & & 207 & A & $07 / 11 / 90$ & & $5567: 01-05$ & $\begin{array}{l}\text { Inspection was made to } \\
\text { determine if any change } \\
\text { in annulus conditions had } \\
\text { occurred during the } 6 \\
\text { weeks the ventilation fan } \\
\text { was out of service. No } \\
\text { change had occurred. }\end{array}$ \\
\hline & & $\underline{235}$ & A & $04 / 10 / 90$ & $5441: 06$ & & No change \\
\hline & & 235 & A & $07 / 11 / 90$ & & $5568: 01-05$ & $\begin{array}{l}\text { Inspection was made to } \\
\text { determine if any change } \\
\text { in annulus conditions had } \\
\text { occurred during the } 6 \\
\text { weeks the ventilation fan } \\
\text { was out of service. No } \\
\text { change had occurred. }\end{array}$ \\
\hline & & $\underline{259}$ & A & $04 / 10 / 90$ & 5441:07 & & No change \\
\hline & & 259 & $A$ & $07 / 11 / 90$ & & $5569: 01-05$ & $\begin{array}{l}\text { Inspection was made to } \\
\text { determine if any change } \\
\text { in annulus conditions had } \\
\text { occurred during the } 6 \\
\text { weeks the ventilation fan } \\
\text { was out of service. No } \\
\text { change had occurred. }\end{array}$ \\
\hline
\end{tabular}


TABLE 1

SUMMARY OF INSPECTICNS

\begin{tabular}{|c|c|c|c|c|c|c|c|}
\hline \multirow[b]{2}{*}{ Area } & \multirow{2}{*}{$\begin{array}{c}\text { Tank } \\
\text { or } \\
\text { Vessel } \\
\end{array}$} & \multirow{2}{*}{$\begin{array}{l}\text { Inspec- } \\
\text { tion } \\
\text { Port } \\
\end{array}$} & \multirow{2}{*}{$\begin{array}{l}\text { Annulus } \\
\text { or } \\
\text { Interior }\end{array}$} & \multirow[b]{2}{*}{ Date } & \multicolumn{2}{|c|}{$\begin{array}{l}\text { Type of Inspection and } \\
\text { Identification Numbers }\end{array}$} & \multirow[b]{2}{*}{ Remarks } \\
\hline & & & & & HAP & DP $\quad P S P$ & \\
\hline \multirow[t]{3}{*}{$H$} & & $\overline{\text { East }}$ & $A$ & $\overline{04 / 10 / 90}$ & $5441: 04$ & & $\begin{array}{l}\text { Stains and marks visible } \\
\text { in the annulus were } \\
\text { caused by the inleakage } \\
\text { of water. }\end{array}$ \\
\hline & & North & A & $04 / 10 / 90$ & $5441: 01$ & & No change \\
\hline & & 31611 & I & $03 / 15 / 90$ & $5388: 01-02$ & & $\begin{array}{l}\text { Inspection was made to } \\
\text { determine if the absence } \\
\text { of liquid was the cause } \\
\text { of reel tape malfunc- } \\
\text { tions. Except for a } \\
\text { small pool of liquid } \\
\text { below the 3'6" riser, the } \\
\text { waste surface was not } \\
\text { liquid. }\end{array}$ \\
\hline \multirow[t]{7}{*}{$H$} & 15 & 010 & A & $04 / 11 / 90$ & $5453: 08$ & & No change \\
\hline & & 010 & A & $09 / 04 / 90$ & & $5637: 01-15$ & $\begin{array}{l}\text { The anmulus floor was } \\
\text { wet. Rainwater leaked } \\
\text { into the annulus during } \\
\text { heavy rainfalls that } \\
\text { occurred the week of } \\
8-21-90 \text {. }\end{array}$ \\
\hline & & 032 & A & $04 / 11 / 90$ & & $5456: 01-17$ & No change \\
\hline & & 055 & A & $04 / 11 / 90$ & & $5455: 01-17$ & No change \\
\hline & & 071 & A & $04 / 11 / 90$ & & $5457: 01-17$ & No change \\
\hline & & 107 & $A$ & $04 / 11 / 90$ & $5453: 04$ & & $\begin{array}{l}\text { Stains and marks visible } \\
\text { in the annulus were } \\
\text { caused by the inleakage } \\
\text { of water. }\end{array}$ \\
\hline & & 107 & A & $09 / 04 / 90$ & & $5640: 01-14$ & $\begin{array}{l}\text { Changes occurred at two } \\
\text { leaksites that are } \\
\text { visible from both riser } \\
107 \text { and } 117 \text {. Apparently } \\
\text { humid conditions prevail- } \\
\text { ed in the annulus after } \\
\text { sufficient rainfall had } \\
\text { leaked into the annulus } \\
\text { to cover the floor. } \\
\text { There was no evidence } \\
\text { that additional waste } \\
\text { leaked into the annulus. } \\
\text { However, changes were } \\
\text { observed in the surface } \\
\text { contours of the leaked } \\
\text { dry waste deposits at } \\
\text { these two leaksites. }\end{array}$ \\
\hline
\end{tabular}


TABLE 1

SUMMARY OF INSPECTIONS

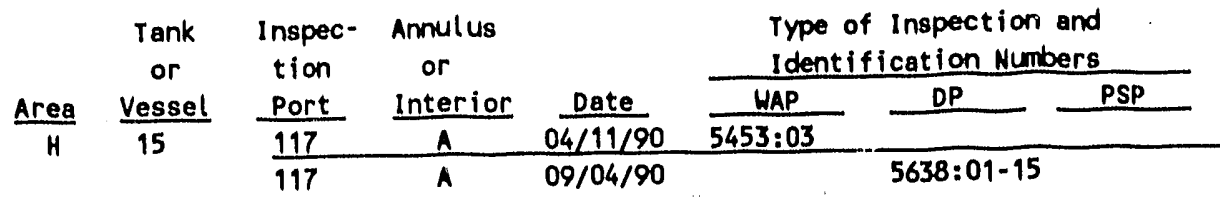

Changes occurred at two

leaksites that are

visible from both riser

107 and 117. Apparently

humid conditions prevail-

ed in the annulus after

sufficient rainfall had

leaked into the annulus

to cover the floor.

There was no evidence

that additional waste

leaked into the annulus.

However, changes were

observed in the surface

contours of the leaked

dry waste deposits at

these two leaksites.

\begin{tabular}{lllll}
\hline 137 & A & $04 / 11 / 90$ & $5453: 02$ & \\
\hline 137 & A & $08 / 29 / 90$ & $5631: 01-12$
\end{tabular}

No change

Changes occurred at the three leaksites beneath riser 137. Apparently humid conditions prevail.. ed in the annulus after sufficient rainwater leaked into the annulus to cover the floor. 6.86 inches of rain fell during the preceding week. Two of the leaksites appear to have become temporarily active and a small quantity of addi tional waste seeped into the annulus. The dry waste deposit had fallen away from the third leaksite but there was no evidence that additional waste had seeped from this site.

\begin{tabular}{lll}
\hline $137 \quad 10 / 03 / 90$ & $5661: 01-17$ & $\begin{array}{l}\text { A small quantity of waste } \\
\text { had seeped from the tank } \\
\text { into the annulus. A very } \\
\text { small nodule, less than } \\
\text { an inch in diameter, of } \\
\text { dry waste had formed at }\end{array}$ \\
\end{tabular}


TABLE 1

SUMMARY OF INSPECTIONS

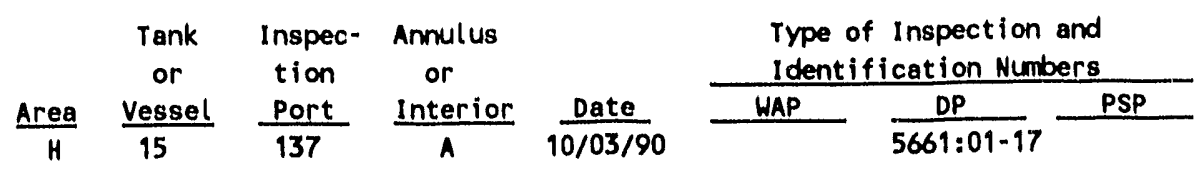

the leaksite where the dry waste deposits had fallen away in August 1990.

\begin{tabular}{|c|c|c|c|}
\hline 137 & $10 / 08 / 90$ & $5667: 01-11$ & No change \\
\hline 137 & $10 / 16 / 90$ & $5672: 01-10$ & The waste deposit observ- \\
\hline
\end{tabular}
ed on 10-3-90 had fallen from the tank wall. Additional seepage had occurred forming three small nodules of dry waste. The total volume of dry waste deposited at the site was estimated to be about 1 cubic centimeter.

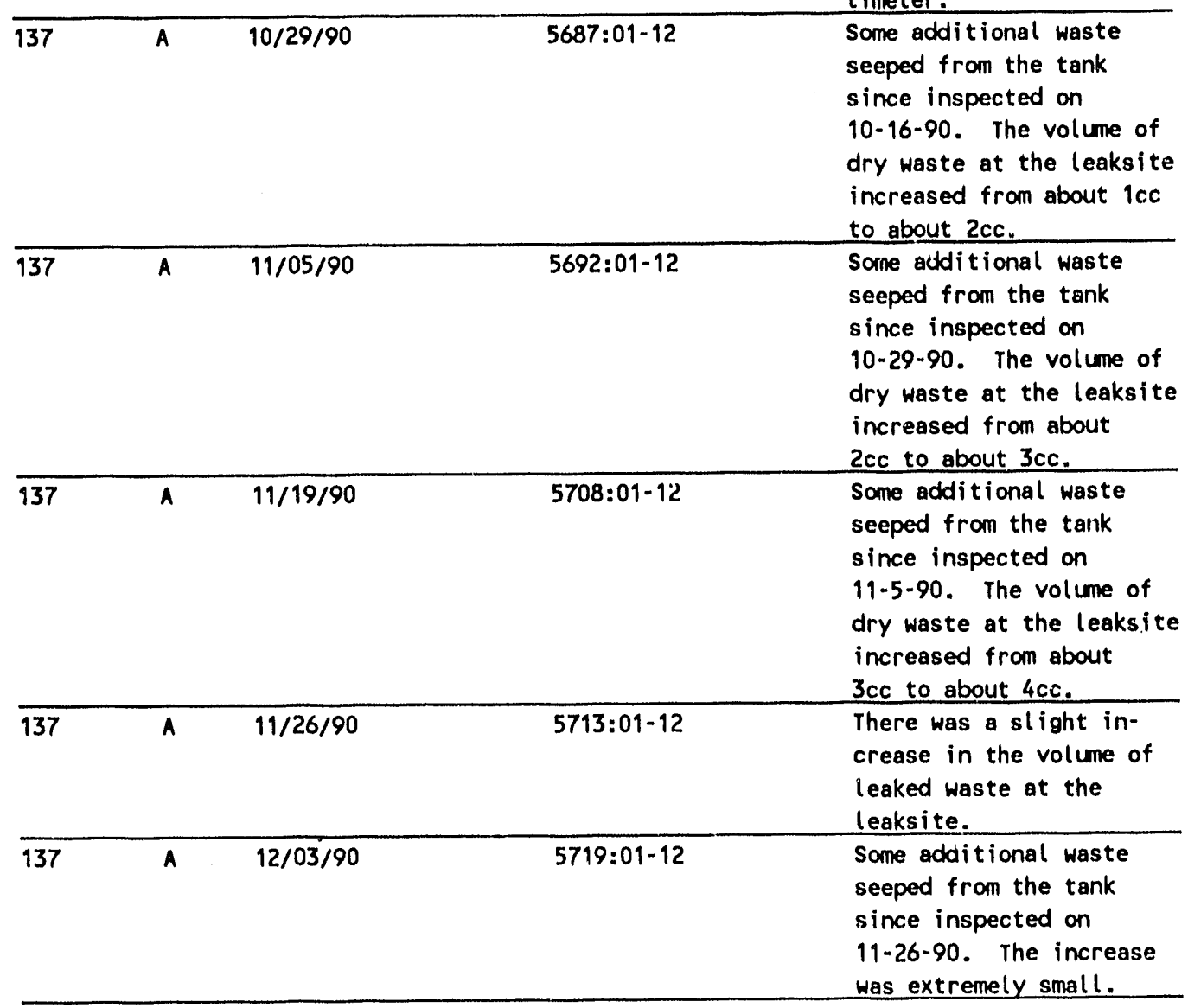


TABLE 1

SUMMARY OF INSPECTIONS

\begin{tabular}{|c|c|c|c|c|c|c|c|}
\hline \multirow[b]{2}{*}{ Area } & \multirow{2}{*}{$\begin{array}{c}\text { Tank } \\
\text { or } \\
\text { Vessel } \\
\end{array}$} & \multirow{2}{*}{$\begin{array}{l}\text { Inspec- } \\
\text { tion } \\
\text { Port }\end{array}$} & \multirow{2}{*}{$\begin{array}{l}\text { Annulus } \\
\text { or } \\
\text { Interior }\end{array}$} & \multirow[b]{2}{*}{ Date } & \multicolumn{3}{|c|}{$\begin{array}{l}\text { Type of Inspection and } \\
\text { Identification Numbers }\end{array}$} \\
\hline & & & & & HAP & $\mathrm{DP}$ & PSP \\
\hline H & 15 & $\overline{137}$ & $A$ & $12 / 10 / 90$ & & $5724: 0$ & \\
\hline
\end{tabular}

\begin{tabular}{lllll}
\hline 137 & $A$ & $12 / 17 / 90$ & \\
\hline 137 & $A$ & $12 / 26 / 90$ & $5729: 01-09$ \\
\hline 171 & $A$ & $04 / 11 / 90$ & $5453: 05$ & $5734: 01-10$ \\
\hline 171 & A & $09 / 04 / 90$ & & $5639: 01-15$
\end{tabular}

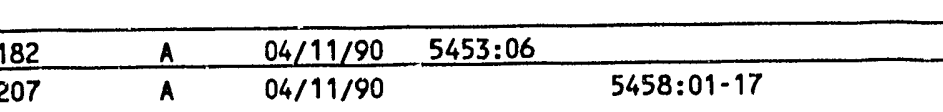

\begin{tabular}{lllll}
\hline 223 & A & $04 / 11 / 90$ & $5459: 01-17$ \\
\hline East & A & $04 / 11 / 90$ & $5454: 01-17$ \\
\hline North & A & $04 / 11 / 90$ & $5451: 01-17$ \\
\hline North & A & $04 / 11 / 90$ & $5453: 01$ & \\
\hline North & A & $08 / 27 / 90$ & $5629: 01-09$
\end{tabular}


TABLE 1

SUMMARY OF INSPECTIONS

\begin{tabular}{|c|c|c|c|c|c|c|c|c|}
\hline \multirow{3}{*}{$\frac{\text { Area }}{H}$} & \multirow{3}{*}{$\begin{array}{c}\text { Tank } \\
\text { or } \\
\text { Vessel } \\
15\end{array}$} & \multirow{2}{*}{$\begin{array}{l}\text { Inspec- } \\
\text { tion } \\
\text { Port } \\
\end{array}$} & \multirow{2}{*}{$\begin{array}{l}\text { Annulus } \\
\text { or } \\
\text { Interior }\end{array}$} & \multirow[b]{2}{*}{ Date } & \multicolumn{3}{|c|}{$\begin{array}{l}\text { Type of Inspection and } \\
\text { Identification Numbers }\end{array}$} & \multirow[b]{2}{*}{ Remarks } \\
\hline & & & & & WAP & DP & PSP & \\
\hline & & South & A & $04 / 11 / 90$ & $5453: 07$ & & & No change \\
\hline & & South & $A$ & $08 / 27 / 90$ & & $5630: 01-08$ & & $\begin{array}{l}\text { Photographs were taken to } \\
\text { determine amount of rain- } \\
\text { water in anmulus. The } \\
\text { depth of the rainwater on } \\
\text { the annulus floor was } \\
\text { estimated to be approx- } \\
\text { imatly } 1 \text { inch. }\end{array}$ \\
\hline & & West & A & $04 / 11 / 90$ & & $5452: 01-17$ & & No change \\
\hline & & 001 & 1 & $11 / 14 / 90$ & & & & $\begin{array}{l}\text { CCTV used to document the } \\
\text { configuration of the } \\
\text { waste surface in the } \\
\text { tank. }\end{array}$ \\
\hline & & 001 & I & $11 / 15 / 90$ & & & & $\begin{array}{l}\text { CCTV used to document: the } \\
\text { configuration of the : } \\
\text { waste surface in the } \\
\text { tank. }\end{array}$ \\
\hline & & 006 & I & $05 / 31 / 90$ & & & $5527: 01-72$ & $\begin{array}{l}\text { Photographs were taken to } \\
\text { document the current } \\
\text { conditions in the tank. }\end{array}$ \\
\hline \multirow[t]{6}{*}{$H$} & 16 & $\underline{035}$ & A & $04 / 10 / 90$ & & $5445: 01-17$ & & No change \\
\hline & & 118 & A & $04 / 10 / 90$ & & 5446:01-18 & & No change \\
\hline & & 207 & A & $04 / 10 / 90$ & & $5447: 01-17$ & & No change \\
\hline & & 262 & A & $04 / 10 / 90$ & & $5448: 01-17$ & & $\begin{array}{l}\text { Inspection was made to } \\
\text { document the current } \\
\text { condition of the annulus } \\
\text { beneath riser } 262 \text {. This } \\
\text { is the tirst inspection } \\
\text { at } 262 \text { since } 1976 \text {. } \\
\text { Equipment installed at } \\
\text { this riser from } 1977 \\
\text { through } 1989 \text { made the } \\
\text { riser inaccessible for } \\
\text { inspection purposes. No } \\
\text { unusual condition was } \\
\text { observed. }\end{array}$ \\
\hline & & East & A & $04 / 10 / 90$ & & 5449:01-17 & & No change \\
\hline & & Hest & A & $04 / 10 / 90$ & & $5450: 01-17$ & & No change \\
\hline \multirow[t]{2}{*}{$\mathbf{F}$} & 17 & NH & 1 & $06 / 15 / 90$ & & & $5544: 01-48$ & Normal \\
\hline & & West & 1 & $\begin{array}{c}05 / 17 / 90 \\
.\end{array}$ & & & $5505: 01-48$ & $\begin{array}{l}\text { Water marks and damp } \\
\text { areas were observed where } \\
\text { water had leaked into the } \\
\text { tank at the Southeast } \\
\text { riser }\end{array}$ \\
\hline
\end{tabular}


TABLE 1

SUMMARY OF INSPECTIONS

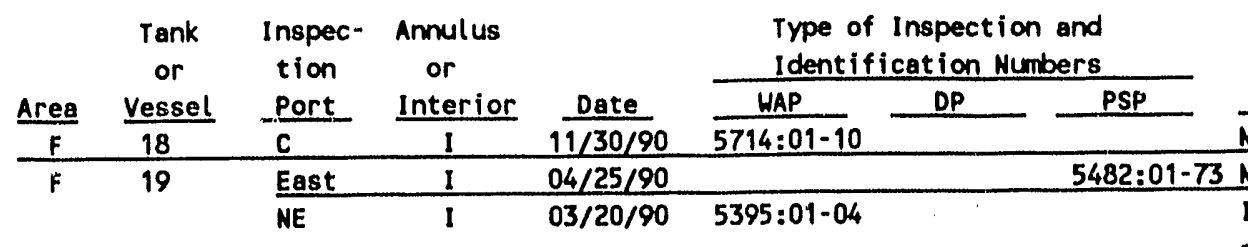
determine if solid waste protruding above the liquid level was the cause of inaccurate reel tape measurements. Ho solid waste was observed above the liquid level.

SH I $03 / 20 / 90 \quad 5394: 01 \quad$ Inspection was made to
determine if solid waste protruding above the liquid level was the : cause of inaccurate reel tape measurements. No solid waste was observed above the liquid level.

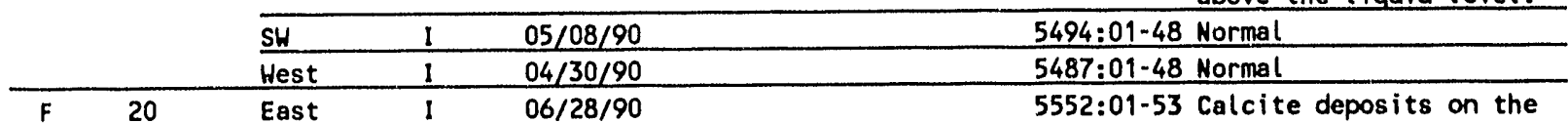
inside of the steel liner indicated that another failure exist in the tank liner. This failure is $26 \mathrm{ft}$. above the tank bottom in the east wall. This makes a total of four failures that have been identified in the tank liner.

NE $\quad 1 \quad 06 / 22 / 90 \quad 5550: 01-50$ No change was observed in
the tank condition except the leaksite identified in the inspection made at east riser on 6-28.

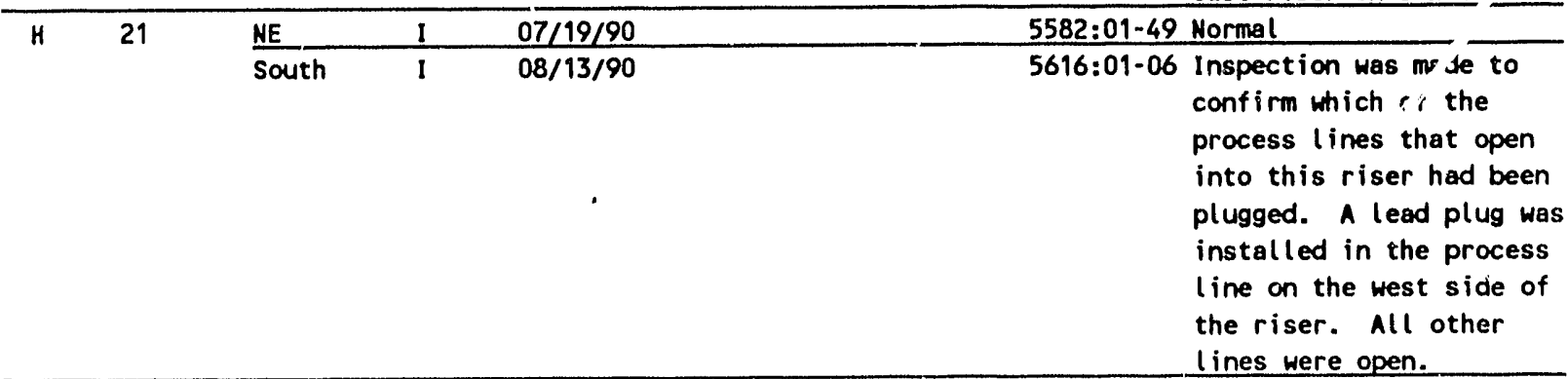


TABLE 1

SUMMARY OF INSPECTIONS

\begin{tabular}{|c|c|c|c|c|c|c|c|}
\hline \multirow[b]{2}{*}{ Area } & \multirow{2}{*}{$\begin{array}{c}\text { Tank } \\
\text { or } \\
\text { Vessel }\end{array}$} & \multirow{2}{*}{$\begin{array}{l}\text { Inspec- } \\
\text { tion } \\
\text { Port } \\
\end{array}$} & \multirow{2}{*}{$\begin{array}{l}\text { Annulus } \\
\text { or } \\
\text { Interior }\end{array}$} & \multirow[b]{2}{*}{ Date } & \multicolumn{3}{|c|}{$\begin{array}{l}\text { Type of Inspection and } \\
\text { Identification Numbers }\end{array}$} \\
\hline & & & & & WAP & $D P$ & PSP \\
\hline$H$ & 22 & NH & 1 & $01 / 17 / 90$ & & & \\
\hline
\end{tabular}

Remarks

Inspection using CCTV revealed leakage into the spray chamber when the transfer pump was operated.

NW I $08 / 31 / 90 \quad 5641: 01-50$ A large area beneath the
NG riser was wet and stained. Investigation showed water trickling into the tank from the exhaust outlet in the NW riser.

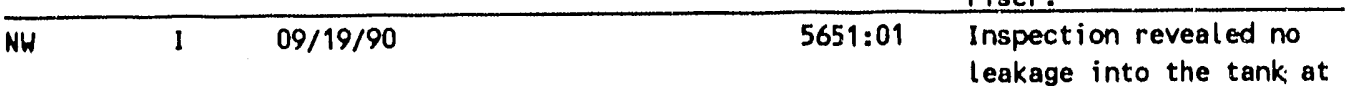
the ventilation exhaust outle'i during hydrostatic test of the reheater.

NH $\quad$ I $09 / 24 / 90 \quad$ VISUAL
Visual inspection revealed no leakage into the tank at the ventilation exhaust outlet during hydrostatic test of the reheater.

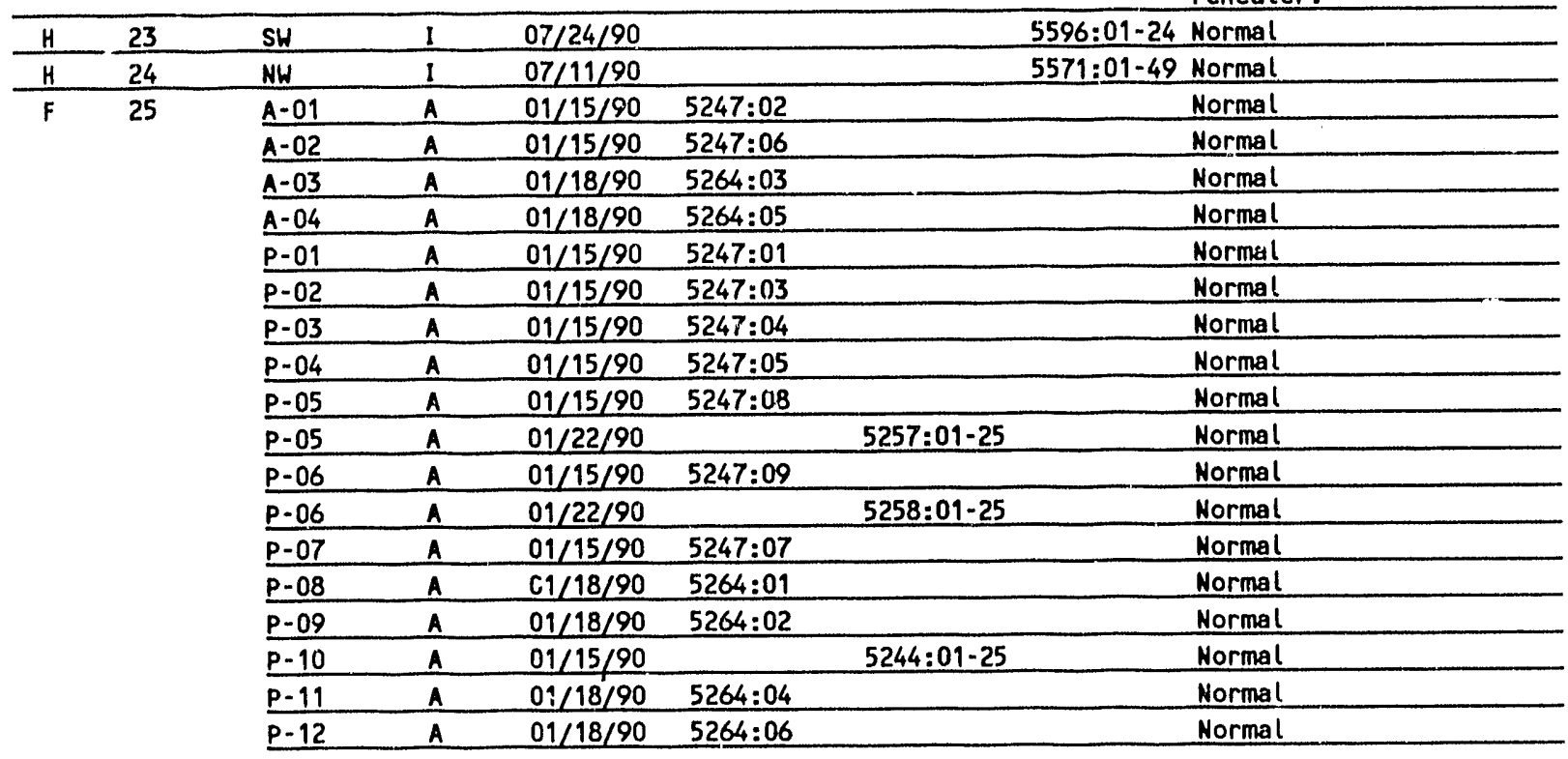


TABLE 1

SUMMARY OF INSPECTIONS

\begin{tabular}{|c|c|c|c|c|c|c|c|}
\hline \multirow{2}{*}{ rea } & \multirow{2}{*}{$\begin{array}{l}\text { Tank } \\
\text { or } \\
\text { Vessel }\end{array}$} & \multirow{2}{*}{$\begin{array}{l}\text { Inspec- } \\
\text { tion } \\
\text { Port }\end{array}$} & \multirow{2}{*}{$\begin{array}{l}\text { Anmulus } \\
\text { or } \\
\text { Interior }\end{array}$} & \multirow[b]{2}{*}{ Date } & \multicolumn{3}{|c|}{$\begin{array}{l}\text { Type of Inspection and } \\
\text { Identification Numbers }\end{array}$} \\
\hline & & & & & HAP & $D P$ & PSP \\
\hline$F$ & 25 & $p-13$ & A & $01 / 15 / 90$ & & $5245: 01-25$ & \\
\hline
\end{tabular}

Remarks

White particles observed on the annulus floor and atop the purge duct appeared to be gilsulate insulation.

\begin{tabular}{llll}
\hline P-14 A & $01 / 15 / 90$ & $5246: 01-25$ & White particles observed
\end{tabular}
on the annulus floor and atop the purge duct appeared to be gilsulate insulation.

\begin{tabular}{|c|c|c|c|c|c|c|}
\hline \multirow[t]{18}{*}{$\mathbf{F}$} & 26 & A.01 & A & $01 / 18 / 90$ & 5265:02 & Normal \\
\hline & & A-02 & A & $01 / 18 / 90$ & $5265: 06$ & Normal \\
\hline & & A-03 & A & $01 / 18 / 90$ & $5265: 10$ & Normal \\
\hline & & A-04 & A & $01 / 18 / 90$ & $5265: 13$ & Normal \\
\hline & & $p-01$ & A & $01 / 18 / 90$ & $5265: 01$ & Normal \\
\hline & & $\mathrm{p}-02$ & A & $01 / 18 / 90$ & 5265:03 & Normal \\
\hline & & $p-03$ & A & $01 / 18 / 90$ & 5265:04 & Normal \\
\hline & & P-04 & A & $01 / 18 / 90$ & $5265: 05$ & Normal \\
\hline & & P-05 & A & $01 / 15 / 90$ & $5248: 01-25$ & Normal \\
\hline & & $p-06$ & A & $01 / 15 / 90$ & $5249: 01-25$ & Normal \\
\hline & & $\mathrm{P}-07$ & A & $01 / 18 / 90$ & $5265: 07$ & Normal \\
\hline & & p-08 & A & $01 / 18 / 90$ & $5265: 08$ & Normal \\
\hline & & $\mathrm{p} .09$ & A & $01 / 18 / 90$ & 5265:09 & Normal \\
\hline & & $p-10$ & A & $01 / 18 / 90$ & 5265:11 & Normal \\
\hline & & $p-11$ & A & $01 / 18 / 90$ & $5265: 12$ & Normal \\
\hline & & $p-12$ & A & $01 / 15 / 90$ & $5250: 01-25$ & Normal \\
\hline & & $p-13$ & $A$ & $01 / 15 / 90$ & $5252: 01-25$ & $\begin{array}{l}\text { Stains and marks visible } \\
\text { in the annulus Here } \\
\text { caused by the inleakage } \\
\text { of water. }\end{array}$ \\
\hline & & $p-14$ & A & $01 / 15 / 90$ & $5251: 01-25$ & Normal \\
\hline \multirow[t]{12}{*}{$F$} & 27 & A-01 & A & $01 / 22 / 90$ & $5267: 13$ & Normal \\
\hline & & A-02 & A & $01 / 22 / 90$ & $5267: 05$ & Normal \\
\hline & & A-03 & A & $01 / 22 / 90$ & $5267: 09$ & Normal \\
\hline & & A-04 & A & $01 / 22 / 90$ & 5267:12 & Normal \\
\hline & & $p-01$ & A & $01 / 22 / 90$ & $5267: 01$ & Normal \\
\hline & & $\mathrm{p}-02$ & A & $01 / 22 / 90$ & $5267: 02$ & Normal \\
\hline & & $p-03$ & A & $01 / 22 / 90$ & $5267: 03$ & Normal \\
\hline & & p-04 & A & $01 / 22 / 90$ & 5267:04 & Normal \\
\hline & & $p-05$ & A & $01 / 18 / 90$ & 5253:01-25 & Normal \\
\hline & & $p-06$ & A & $01 / 18 / 90$ & $5254: 01-25$ & Normal \\
\hline & & $p-07$ & A & $01 / 22 / 90$ & 5267:06 & Normal \\
\hline & & $p-08$ & A & $01 / 22 / 90$ & $5267: 07$ & Normal \\
\hline
\end{tabular}


TABLE 1

SUMMARY OF INSPECTIONS

\begin{tabular}{|c|c|c|c|c|c|c|c|}
\hline \multirow[b]{2}{*}{ Area } & \multirow{2}{*}{$\begin{array}{c}\text { Tank } \\
\text { or } \\
\text { Vessel } \\
\end{array}$} & \multirow{2}{*}{$\begin{array}{l}\text { Inspec- } \\
\text { tion } \\
\text { Port } \\
\end{array}$} & \multirow{2}{*}{$\begin{array}{l}\text { Annulus } \\
\text { or } \\
\text { Interior }\end{array}$} & \multirow[b]{2}{*}{ Date } & \multicolumn{2}{|c|}{$\begin{array}{l}\text { Type of Inspection and } \\
\text { Identification Numbers }\end{array}$} & \multirow[b]{2}{*}{ Remarks } \\
\hline & & & & & WAP & DP $\quad P S P$ & \\
\hline \multirow[t]{6}{*}{$\mathbf{F}$} & & p-09 & $A$ & $01 / 22 / 90$ & $5267: 08$ & & Normal \\
\hline & & $p-10$ & A & $01 / 22 / 90$ & $5267: 10$ & & Normal \\
\hline & & $p-11$ & A & $01 / 22 / 90$ & $5267: 11$ & & Normal \\
\hline & & $p-12$ & A & $01 / 18 / 90$ & & $5259: 01-25$ & Normal \\
\hline & & p-13 & $A$ & $01 / 18 / 90$ & & $5255: 01-25$ & Normal \\
\hline & & $p-14$ & A & $01 / 18 / 90$ & & $5260: 01-25$ & Normal \\
\hline \multirow[t]{18}{*}{$\mathbf{F}$} & 28 & A-01 & A & $01 / 22 / 90$ & $5266: 12$ & & Normal \\
\hline & & A-02 & A & $01 / 22 / 90$ & $5266: 05$ & & Normal \\
\hline & & A-03 & A & $01 / 22 / 90$ & $5266: 08$ & & Normal \\
\hline & & $A-04$ & A & $01 / 22 / 90$ & 5266:10 & & Normal \\
\hline & & $p-01$ & $A$ & $01 / 22 / 90$ & $5266: 01$ & & $\begin{array}{l}\text { Condition of the tank and } \\
\text { annulus appeared normal. } \\
\text { The calcite deposits } \\
\text { in the annulus had not } \\
\text { changed since inspected } \\
\text { in } 1983 \text {. }\end{array}$ \\
\hline & & p-02 & A & $01 / 26 / 90$ & & 5272:01-25 & Normal \\
\hline & & P.03 & A & $01 / 22 / 90$ & $5266: 02$ & & Normal \\
\hline & & $\mathrm{p}-04$ & A & $01 / 22 / 90$ & $5266: 03$ & & Normal \\
\hline & & $\mathrm{p}-05$ & A & $01 / 18 / 90$ & & $5262: 01-25$ & Normal \\
\hline & & p-06 & A & $01 / 22 / 90$ & 5266:04 & & Normal \\
\hline & & $p-07$ & A & $01 / 22 / 90$ & 5266:06 & & Normal \\
\hline & & $p-08$ & A & $01 / 22 / 90$ & 5266:07 & & Normal \\
\hline & & P-09 & A & $01 / 26 / 90$ & & 5273:01-25 & Normal \\
\hline & & $p-10$ & A & $01 / 18 / 90$ & & $5261: 01-25$ & Normal \\
\hline & & $p-11$ & A & $01 / 22 / 90$ & $5266: 09$ & & Normal \\
\hline & & $\mathrm{p}-12$ & A & $01 / 22 / 90$ & $5266: 11$ & & Normal \\
\hline & & $p-13$ & A & $01 / 18 / 90$ & & 5263:01-25 & Normal \\
\hline & & $p-14$ & A & $01 / 26 / 90$ & & $5274: 01-25$ & Normal \\
\hline \multirow[t]{10}{*}{ H } & 29 & & $A$ & $11 / 29 / 90$ & & & $\begin{array}{l}\text { CCTV inspection of } \\
\text { annulus dampers revealed } \\
\text { that the damper to the } \\
\text { outer annulus was stuck } \\
\text { in the closed position. }\end{array}$ \\
\hline & & A-01 & A & $05 / 08 / 90$ & 5492:01 & & Normal \\
\hline & & A-02 & $A$ & $05 / 08 / 90$ & 5492:04 & & Normal \\
\hline & & A-03 & A & $05 / 08 / 90$ & 5492:07 & & Normal \\
\hline & & A- 04 & A & $05 / 08 / 90$ & 5492:10 & & Normal \\
\hline & & $p-01$ & A & $08 / 07 / 90$ & 5608:01 & & Normal \\
\hline & & $\mathrm{p}-02$ & A & $05 / 08 / 90$ & 5492:09 & & Normal \\
\hline & & $p-03$ & $A$ & $04 / 17 / 90$ & & $5473: 01-25$ & Normal \\
\hline & & P. 04 & A & $05 / 08 / 90$ & 5492:11 & & Normal \\
\hline & & $p-05$ & $A$ & $05 / 08 / 90$ & 5492:12 & & Normal \\
\hline
\end{tabular}


TABLE 1

SUMAARY OF INSPECTIONS

\begin{tabular}{|c|c|c|c|c|c|c|c|c|}
\hline \multirow[b]{2}{*}{ Area } & \multirow{2}{*}{$\begin{array}{c}\text { Tank } \\
\text { or } \\
\text { Vessel } \\
\end{array}$} & \multirow{2}{*}{$\begin{array}{l}\text { Inspec- } \\
\text { tion } \\
\text { Port } \\
\end{array}$} & \multirow{2}{*}{$\begin{array}{l}\text { Annulus } \\
\text { or } \\
\text { Interior }\end{array}$} & \multirow[b]{2}{*}{ Date } & \multicolumn{3}{|c|}{$\begin{array}{l}\text { Type of Inspection and } \\
\text { Identification Numbers }\end{array}$} & \multirow[b]{2}{*}{ Remarks } \\
\hline & & & & & WAP & DP & PSP & \\
\hline \multirow[t]{9}{*}{$H$} & 29 & $p-06$ & A & $04 / 17 / 90$ & & $5474: 01-25$ & & Normal \\
\hline & & $\mathrm{p}-07$ & A & $05 / 08 / 90$ & 5492:02 & & & Normal \\
\hline & & $P-08$ & A & $05 / 08 / 90$ & 5492:03 & & & Normal \\
\hline & & $\mathrm{p}-09$ & A & $04 / 17 / 90$ & & $5475: 01-25$ & & Normal \\
\hline & & $p-10$ & A & $04 / 17 / 90$ & & $5476: 01-25$ & & Normal \\
\hline & & $p-11$ & A & $05 / 08 / 90$ & 5492:05 & & & Normal \\
\hline & & $p-12$ & A & $05 / 08 / 90$ & 5492:06 & & & Normal \\
\hline & & $p-13$ & A & $04 / 17 / 90$ & & $5477: 01-25$ & & Normal \\
\hline & & $p-14$ & $A$ & $05 / 08 / 90$ & 5492:08 & & & Normal \\
\hline \multirow[t]{18}{*}{ H } & 30 & A-01 & A & $05 / 08 / 90$ & $5493: 01$ & & & Normal \\
\hline & & $A-02$ & A & $05 / 08 / 90$ & 5493:04 & & & Normal \\
\hline & & A-03 & A & $05 / 08 / 90$ & 5493:07 & & & Normal \\
\hline & & A-04 & A & $05 / 08 / 90$ & 5493:11 & & & Normal \\
\hline & & $\mathrm{P}-01$ & A & $05 / 08 / 90$ & 5493:09 & & & Normal \\
\hline & & $\mathrm{p}-02$ & A & $05 / 08 / 90$ & $5493: 10$ & & & Normal \\
\hline & & $p-03$ & A & $05 / 08 / 90$ & & $5495: 01-25$ & & Normal \\
\hline & & $p-04$ & A & $05 / 08 / 90$ & 5493:12 & & & Normal \\
\hline & & p-05 & A & $05 / 08 / 90$ & 5493:13 & & & Normal \\
\hline & & $p-06$ & A & $05 / 08 / 90$ & & $5496: 01-25$ & & Normal \\
\hline & & $\mathrm{p}-07$ & $A$ & $05 / 08 / 90$ & 5493:02 & & & Normal \\
\hline & & $p-08$ & A & $05 / 08 / 90$ & 5493:03 & & & Normal \\
\hline & & $p-09$ & A & $05 / 08 / 90$ & & $5497: 01-25$ & & Normal \\
\hline & & $p-10$ & A & $05 / 08 / 90$ & & $5498: 01-25$ & & Normal \\
\hline & & $p-11$ & A & $05 / 08 / 90$ & 5493:05 & & & Normal \\
\hline & & $\mathrm{p}-12$ & A & $05 / 08 / 90$ & 5493:06 & & & Normal \\
\hline & & $p-13$ & A & $05 / 08 / 90$ & & $5499: 01-25$ & & $\begin{array}{l}\text { Stains and marks visible } \\
\text { in the annulus were } \\
\text { caused by the inleakage } \\
\text { of water. }\end{array}$ \\
\hline & & $P-14$ & A & $05 / 08 / 90$ & 5493:08 & & & Normal \\
\hline \multirow[t]{13}{*}{ H } & 31 & $\Lambda-01$ & A & $05 / 18 / 90$ & 5506:01 & & & Normal \\
\hline & & A-03 & A & $05 / 18 / 90$ & 5506:06 & & & Normal \\
\hline & & $\Lambda-04$ & A & $05 / 23 / 90$ & 5522:01 & & & Normal \\
\hline & & $\mathrm{P}-01$ & A & $06 / 15 / 90$ & 5537:03 & & & Normal \\
\hline & & P.02 & A & $06 / 15 / 90$ & 5537:02 & & & Normal \\
\hline & & $\mathrm{p}-03$ & A & $05 / 24 / 90$ & & 5513:01-25 & & Normal \\
\hline & & P. 04 & $A$ & $05 / 23 / 90$ & 5522:02 & & & Normal \\
\hline & & P-05 & A & $06 / 15 / 90$ & $5537: 01$ & & & Normal \\
\hline & & $\mathrm{p}-06$ & A & $06 / 25 / 90$ & & $5545: 01-25$ & & Normal \\
\hline & & $\mathrm{P}-07$ & A & $05 / 18 / 90$ & 5506:02 & & & Normal \\
\hline & & $\mathrm{p}-08$ & A & $05 / 18 / 90$ & $5506: 03$ & & & Normal \\
\hline & & P-09 & A & $06 / 15 / 90$ & & 5533:01-05 & & Normal \\
\hline & & $p-10$ & A & $05 / 24 / 90$ & & $5514: 01-25$ & & Normal \\
\hline
\end{tabular}


TABLE 1

SUMMARY OF INSPECTIONS

\begin{tabular}{|c|c|c|c|c|c|c|c|}
\hline \multirow[b]{2}{*}{ Area } & \multirow{2}{*}{$\begin{array}{c}\text { Tank } \\
\text { or } \\
\text { Vessel } \\
\end{array}$} & \multirow{2}{*}{$\begin{array}{l}\text { Inspec- } \\
\text { tion } \\
\text { Port } \\
\end{array}$} & \multirow{2}{*}{$\begin{array}{l}\text { Annulus } \\
\text { or } \\
\text { Interior }\end{array}$} & \multirow[b]{2}{*}{ Date } & \multicolumn{2}{|c|}{$\begin{array}{l}\text { Type of Inspection and } \\
\text { Identification Numbers }\end{array}$} & \multirow[b]{2}{*}{ Remarks } \\
\hline & & & & & HAP & $D P \quad P S P$ & \\
\hline \multirow[t]{7}{*}{ H } & 31 & $p-11$ & $A$ & $05 / 18 / 90$ & 5506:04 & & Normal \\
\hline & & $p-12$ & $A$ & $05 / 18 / 90$ & 5506:05 & & Normal \\
\hline & & $p-12$ & A & $06 / 15 / 90$ & $5537: 04$ & & Normal \\
\hline & & $p-13$ & A & $06 / 15 / 90$ & & $5534: 01-25$ & Normal \\
\hline & & $p-14$ & $A$ & $05 / 18 / 90$ & 5506:07 & & Normal \\
\hline & 32 & CRC & & $06 / 06 / 90$ & & & $\begin{array}{l}\text { CCTV used to inspect the } \\
\text { overall condition. } \\
\text { No unusual condition was } \\
\text { observed. }\end{array}$ \\
\hline & & CRC & & $10 / 30 / 90$ & & & $\begin{array}{l}\text { CCTV used to inspect the } \\
\text { screen and welds. No } \\
\text { unusual condition was } \\
\text { observed. }\end{array}$ \\
\hline \multirow[t]{16}{*}{$H$} & 32 & & $A$ & $11 / 29 / 90$ & & & $\begin{array}{l}\text { CCTV inspection of } \\
\text { annulus dampers verified } \\
\text { that both dampers were } \\
\text { operational. }\end{array}$ \\
\hline & & A-01 & A & $05 / 98 / 90$ & 5507:01 & & Normal \\
\hline & & A-02 & A & $05 / 18 / 90$ & 5507:04 & & Normal \\
\hline & & $A-03$ & A & $05 / 18 / 90$ & 5507:07 & & Normal \\
\hline & & A- 04 & $A$ & $05 / 18 / 90$ & 5507:12 & & Normal \\
\hline & & P.02 & A & $05 / 18 / 90$ & $5507: 10$ & & $\begin{array}{l}\text { Normal } \\
\text { Normal }\end{array}$ \\
\hline & & $P-02$ & A & $05 / 18 / 90$ & $5507: 11$ & & $\begin{array}{l}\text { Normal } \\
\text { Normal }\end{array}$ \\
\hline & & P-03 & $A$ & $05 / 24 / 90$ & & $5515: 01-25$ & Normal \\
\hline & & $\underline{p-04}$ & A & $05 / 18 / 90$ & 5507:13 & & Normal \\
\hline & & P. 05 & $A$ & $06 / 15 / 90$ & 5538:01 & & Normal \\
\hline & & $p-06$ & $A$ & $05 / 24 / 90$ & & $5516: 01-24$ & Normal \\
\hline & & $p-07$ & $A$ & $05 / 18 / 90$ & 5507:02 & & Normal \\
\hline & & $p-08$ & A & $05 / 18 / 90$ & $5507: 03$ & & Normal \\
\hline & & P-09 & A & $06 / 15 / 90$ & & $5535: 01-25$ & Normal \\
\hline & & $p-10$ & $A$ & $05 / 24 / 90$ & & $5517: 01-25$ & $\begin{array}{l}\text { Calcite deposits on the } \\
\text { duct and annulus floor } \\
\text { were caused by the in- } \\
\text { leakage of water. }\end{array}$ \\
\hline & & $P-10$ & A & $06 / 15 / 90$ & & $5543: 01-12$ & $\begin{array}{l}\text { Inspection was made to } \\
\text { determine the route of } \\
\text { water leaking into the } \\
\text { anmulus. Calcite } \\
\text { deposits indicated that } \\
\text { water had entered at bolt } \\
\text { holes in the secondary } \\
\text { liner for the annulus } \\
\text { cover plate support } \\
\text { brackets. }\end{array}$ \\
\hline
\end{tabular}


TABLE 1

SUMMARY OF INSPECTIONS

\begin{tabular}{|c|c|c|c|c|c|c|c|}
\hline \multirow{3}{*}{$\frac{\text { Area }}{H}$} & \multirow{2}{*}{$\begin{array}{l}\text { Tank } \\
\text { or } \\
\text { Vessel } \\
\end{array}$} & \multirow{2}{*}{$\begin{array}{l}\text { Inspec- } \\
\text { tion } \\
\text { Port } \\
\end{array}$} & \multirow{2}{*}{$\begin{array}{l}\text { Annulus } \\
\text { or } \\
\text { Interior }\end{array}$} & \multirow[b]{2}{*}{ Date } & \multicolumn{2}{|c|}{$\begin{array}{l}\text { Type of Inspection and } \\
\text { Identification Numbers }\end{array}$} & \multirow[b]{2}{*}{ Remarks } \\
\hline & & & & & WAP & $D P \quad P S P$ & \\
\hline & 32 & $p-11$ & $A$ & $05 / 18 / 90$ & $5507: 05$ & & Normal \\
\hline & & $p-12$ & $A$ & $05 / 18 / 90$ & 5507:06 & & Normal \\
\hline & & $\mathrm{p}-13$ & A & $06 / 15 / 90$ & & $5536: 01-25$ & Normal \\
\hline & & $\mathrm{p}-14$ & A & $05 / 18 / 90$ & 5507:08 & & Normal \\
\hline & & $p-15$ & A & $05 / 18 / 90$ & 5507:09 & & Normal \\
\hline \multirow[t]{20}{*}{$\mathbf{F}$} & 33 & A-01 & A & $03 / 08 / 90$ & 5367:01 & & Normal \\
\hline & & $1-02$ & $A$ & $03 / 08 / 90$ & 5367:03 & & Normal \\
\hline & & A-03 & A & $03 / 12 / 90$ & 5375:05 & & Normal \\
\hline & & A-04 & $A$ & $03 / 08 / 90$ & $5367: 08$ & & Normal \\
\hline & & $p-01$ & A. & $03 / 08 / 90$ & $5367: 06$ & & Normal \\
\hline & & $\mathrm{P}-02$ & $A$ & $03 / 08 / 90$ & 5367:07 & & Normal \\
\hline & & $p-03$ & A & $03 / 07 / 90$ & & $5359: 01-25$ & Normal \\
\hline & & $\mathrm{p}-04$ & $A$ & $03 / 08 / 90$ & 5367:09 & & Normal \\
\hline & & $p-05$ & A & $03 / 08 / 90$ & $5367: 10$ & & Normal \\
\hline & & $p-06$ & $A$ & $03 / 07 / 90$ & & $5360: 01-25$ & Normal \\
\hline & & $p-07$ & A & $03 / 08 / 90$ & 5367:02 & & Normal \\
\hline & & $p-08$ & $A$ & $03 / 12 / 90$ & 5375:01 & & Normal \\
\hline & & P-09 & A & $03 / 07 / 90$ & & $5361: 01-25$ & Normal \\
\hline & & $p-10$ & A & $03 / 07 / 90$ & & $5362: 01-25$ & Normal \\
\hline & & $p-11$ & A & $03 / 12 / 90$ & 5375:02 & & Normal \\
\hline & & $p-12$ & A & $03 / 12 / 90$ & 5375:03 & & Normal \\
\hline & & $p-13$ & A & $03 / 07 / 90$ & & 5373:01-25 & Normal \\
\hline & & $\mathrm{p}-14$ & $A$ & $03 / 12 / 90$ & $5375: 04$ & & Normal \\
\hline & & $p-15$ & A & $03 / 08 / 90$ & $5367: 04$ & & Normal \\
\hline & & $p-16$ & A & $03 / 08 / 90$ & $5367: 05$ & & Normal \\
\hline \multirow[t]{10}{*}{$F$} & 34 & A-01 & $A$ & $03 / 08 / 90$ & $5368: 01$ & & $\begin{array}{l}\text { Stains and marks on the } \\
\text { tank wall were caused by } \\
\text { the inleakage of water. }\end{array}$ \\
\hline & & A-02 & $A$ & $03 / 08 / 90$ & $5368: 04$ & & Normal \\
\hline & & A-03 & A & $03 / 08 / 90$ & $5368: 09$ & & Normal \\
\hline & & $\overline{A-04}$ & $A$ & $03 / 12 / 90$ & $5376: 01$ & & $\begin{array}{l}\text { Water marks indicated } \\
\text { that the riser plug } \\
\text { gasket had allowed rain } \\
\text { water to leak into the } \\
\text { annulus beneath riser } p-3 \\
\text { since inspected on } \\
2-8-89 \text {. }\end{array}$ \\
\hline & & P-01 & $A$ & $03 / 08 / 90$ & $5368: 11$ & & Normal \\
\hline & & $\mathrm{p}-02$ & A & $03 / 08 / 90$ & $5368: 12$ & & Normal \\
\hline & & $\mathrm{p}-03$ & $A$ & $03 / 08 / 90$ & & $5363: 01-25$ & Normal \\
\hline & & $\mathrm{P}-04$ & A & $03 / 08 / 90$ & $5368: 13$ & & Normal \\
\hline & & p-05 & A & $03 / 08 / 90$ & $5368: 14$ & & Normal \\
\hline & & $P-06$ & $\bar{A}$ & $03 / 08 / 90$ & & $5365: 01-25$ & $\begin{array}{l}\text { Stains and marks in } \\
\text { annulus on tank wall were } \\
\text { caused by inleakage of } \\
\text { water. }\end{array}$ \\
\hline
\end{tabular}


TABLE 1

SUMAMARY OF INSPECTIONS

\begin{tabular}{|c|c|c|c|c|c|c|c|}
\hline \multirow[b]{2}{*}{ Area } & \multirow{2}{*}{$\begin{array}{c}\text { Tank } \\
\text { or } \\
\text { Vessel } \\
\end{array}$} & \multirow{2}{*}{$\begin{array}{l}\text { Inspec- } \\
\text { tion } \\
\text { Port } \\
\end{array}$} & \multirow{2}{*}{$\begin{array}{l}\text { Annulus } \\
\text { or } \\
\text { Interior } \\
\end{array}$} & \multirow[b]{2}{*}{ Date } & \multicolumn{2}{|c|}{$\begin{array}{l}\text { Type of Inspection and } \\
\text { Identification Numbers }\end{array}$} & \multirow[b]{2}{*}{ Remarks } \\
\hline & & & & & HAP & $D P \quad P S P$ & \\
\hline \multirow[t]{10}{*}{$F$} & & $p-07$ & $A$ & $03 / 08 / 90$ & $5368: 02$ & & Normal \\
\hline & & $\mathrm{P}-08$ & A & $03 / 08 / 90$ & $5368: 03$ & & Normal \\
\hline & & P.09 & $A$ & $03 / 08 / 90$ & & $5364: 01-25$ & Normal \\
\hline & & $p-10$ & $A$ & $03 / 12 / 90$ & & $5374: 01-25$ & Normal \\
\hline & & $\mathrm{p}-11$ & $A$ & $03 / 08 / 90$ & 5368:05 & & Normal \\
\hline & & $p-12$ & A & $03 / 08 / 90$ & $5368: 06$ & & Normal \\
\hline & & $p-13$ & $A$ & $03 / 08 / 90$ & & $5366: 01-25$ & Normal \\
\hline & & $\mathrm{p}-14$ & A & $03 / 08 / 90$ & $5368: 07$ & & Normal \\
\hline & & $p-15$ & A & $03 / 08 / 90$ & $5368: 08$ & & Normal \\
\hline & & $p-16$ & A & $03 / 08 / 90$ & $5368: 10$ & & Normal \\
\hline \multirow[t]{19}{*}{$H$} & 35 & & $A$ & $11 / 29 / 90$ & & & $\begin{array}{l}\text { CCTV inspection of } \\
\text { annulus dampers verified } \\
\text { that both dampers were } \\
\text { operational. }\end{array}$ \\
\hline & & A-01 & A & $08 / 03 / 90$ & & $5600: 01-25$ & Normal : \\
\hline & & A-02 & A & $08 / 03 / 90$ & & $5601: 01-25$ & Normal \\
\hline & & A-03 & A & $08 / 03 / 90$ & & 5602:01-25 & Normal \\
\hline & & A.04 & A & $08 / 03 / 90$ & & $5603: 01-25$ & Normal \\
\hline & & p-01 & $A$ & $08 / 07 / 90$ & $5609: 01$ & & Normal \\
\hline & & P-02 & A & $08 / 07 / 90$ & 5609:02 & & Normal \\
\hline & & P-03 & A & $08 / 07 / 90$ & 5609:03 & & Normal \\
\hline & & $\mathrm{P}-04$ & A & $08 / 07 / 90$ & 5609:04 & & Normal \\
\hline & & p.05 & $A$ & $08 / 07 / 90$ & 5609:05 & & Normal \\
\hline & & P-06 & A & $08 / 07 / 90$ & $5609: 06$ & & Normal \\
\hline & & $\mathrm{p}-07$ & A & $08 / 07 / 90$ & 5609:07 & & Normal \\
\hline & & $p-08$ & $A$ & $08 / 07 / 90$ & $5609: 08$ & & Normal \\
\hline & & $p-09$ & A & $08 / 07 / 90$ & 5609:09 & & Normal \\
\hline & & $p-10$ & A & $08 / 07 / 90$ & $5609: 10$ & & Normal \\
\hline & & $p-11$ & A & $08 / 07 / 90$ & 5609:11 & & Normal \\
\hline & & p-12 & A & $08 / 07 / 90$ & 5609:12 & & Normal \\
\hline & & $p-13$ & $A$ & $08 / 07 / 90$ & $5609: 13$ & & Normal \\
\hline & & $p-14$ & A & $08 / 07 / 90$ & $5609: 14$ & & Normal \\
\hline \multirow[t]{11}{*}{$H$} & 36 & A-01 & A & $07 / 24 / 90$ & & $5583: 01-25$ & Normal \\
\hline & & A-02 & A & $07 / 24 / 90$ & & $5584: 01-25$ & Normal \\
\hline & & A-03 & A & $07 / 24 / 90$ & & $5585: 01-25$ & Normal \\
\hline & & A- 04 & $A$ & $07 / 24 / 90$ & & $5586: 01-25$ & Normal \\
\hline & & P-01 & A & $07 / 24 / 90$ & 558:3:01 & & Normal \\
\hline & & $\mathrm{p}-02$ & A & $07 / 18 / 90$ & $557: 5: 01$ & & Normal \\
\hline & & $P-03$ & A & $07 / 18 / 90$ & $5576: 02$ & & Normal \\
\hline & & $p-04$ & A & $07 / 18 / 90$ & $5576: 03$ & & Normal \\
\hline & & P.05 & A & $07 / 18 / 90$ & $5576: 04$ & & Normal \\
\hline & & $\mathrm{p}-06$ & A & $07 / 18^{\prime} / 90$ & 5576:05 & & Normal \\
\hline & & p- 07 & $A$ & $07 / 18 / 90$ & 5576:06 & & Normal \\
\hline
\end{tabular}


TABLE 1

SUMMARY OF INSPECTIONS

\begin{tabular}{|c|c|c|c|c|c|c|c|}
\hline \multirow[b]{2}{*}{ Area } & \multirow{2}{*}{$\begin{array}{c}\text { Tank } \\
\text { or } \\
\text { Vessel } \\
\end{array}$} & \multirow{2}{*}{$\begin{array}{l}\text { Inspec- } \\
\text { tion } \\
\text { port }\end{array}$} & \multirow{2}{*}{$\begin{array}{l}\text { Annulus } \\
\text { or } \\
\text { Interior }\end{array}$} & \multirow[b]{2}{*}{ Date } & \multicolumn{2}{|c|}{$\begin{array}{l}\text { Type of Inspection and } \\
\text { Ident if ication Numbers }\end{array}$} & \multirow[b]{2}{*}{ Remarks } \\
\hline & & & & & WAP & $D P \quad P S P$ & \\
\hline \multirow[t]{7}{*}{$H$} & 36 & $p-08$ & $A$ & $07 / 18 / 90$ & 5576:07 & & Normal \\
\hline & & $\mathrm{p}-09$ & $A$ & $07 / 18 / 90$ & $5576: 08$ & & Normal \\
\hline & & $p-10$ & A & $07 / 18 / 90$ & $5576: 09$ & & Normal \\
\hline & & $p-11$ & $A$ & $07 / 18 / 90$ & $5576: 10$ & & Normal \\
\hline & & $p-12$ & $A$ & $07 / 18 / 90$ & $5576: 11$ & & Normal \\
\hline & & $p=13$ & $A$ & $07 / 18 / 90$ & $5576: 12$ & & Normal \\
\hline & & $p-14$ & $A$ & $07 / 18 / 90$ & $5576: 13$ & & Normal \\
\hline \multirow[t]{18}{*}{$H$} & 37 & A-01 & $A$ & $07 / 31 / 90$ & & $5597: 01-23$ & Normal \\
\hline & & A-02 & $A$ & $07 / 31 / 90$ & & $5598: 01-25$ & Normal \\
\hline & & A-03 & $A$ & $07 / 31 / 90$ & & $5599: 01-25$ & Normal \\
\hline & & A-04 & A & $07 / 24 / 90$ & & $5587: 01-25$ & Normal \\
\hline & & $p-01$ & $A$ & $07 / 18 / 90$ & 5577:01 & & Normal \\
\hline & & $p-02$ & A & $07 / 18 / 90$ & $5577: 02$ & & Normal \\
\hline & & $\mathrm{p}-03$ & A & $07 / 18 / 90$ & $5577: 03$ & & Normal \\
\hline & & $p-04$ & A & $07 / 18 / 90$ & $5577: 04$ & & Normal \\
\hline & & $p-05$ & A & $07 / 18 / 90$ & $5577: 05$ & & Normal \\
\hline & & $p-06$ & A & $07 / 18 / 90$ & $5577: 06$ & & Normal \\
\hline & & $p-07$ & A & $07 / 18 / 90$ & 5577:07 & & Normal \\
\hline & & $p-08$ & A & $07 / 18 / 90$ & $5577: 08$ & & Normal \\
\hline & & $\mathrm{p}-09$ & A & $07 / 25 / 90$ & $5589: 01$ & & Normal \\
\hline & & $p-10$ & $A$ & $07 / 18 / 90$ & $5577: 09$ & & $\begin{array}{l}\text { Water marks indicated } \\
\text { that the riser plug } \\
\text { gasket had allowed rain- } \\
\text { water to leak into the } \\
\text { annulus since the } \\
\text { inspection on } 3-1-90 \text {. }\end{array}$ \\
\hline & & $p-11$ & A & $07 / 18 / 90$ & $5577: 10$ & & Normal \\
\hline & & $p-12$ & A & $07 / 18 / 90$ & $5577: 11$ & & Normal \\
\hline & & $p-13$ & A & $07 / 18 / 90$ & $5577: 12$ & & Normal \\
\hline & & $p-14$ & A & $07 / 18 / 90$ & $5577: 13$ & & Normal \\
\hline \multirow[t]{13}{*}{$H$} & 38 & A-01 & A & $02 / 01 / 90$ & & $5289: 01-25$ & Normal \\
\hline & & $\mathrm{A-02}$ & $A$ & $02 / 01 / 90$ & & 5290:01-25 & Normal \\
\hline & & A-03 & A & $02 / 01 / 90$ & & $5291: 01-25$ & Normal \\
\hline & & A-04 & A & $02 / 01 / 90$ & & 5292:01-25 & Normal \\
\hline & & $p-01$ & A & $02 / 01 / 90$ & $5287: 02$ & $\dot{1}$ & Normal \\
\hline & & $p-02$ & A & $02 / 02 / 90$ & 5287:03 & & Normal \\
\hline & & P.03 & A & $02 / 01 / 90$ & $5287: 04$ & & Normal \\
\hline & & $\mathrm{p}-04$ & $A$ & $02 / 01 / 90$ & $5287: 05$ & & Normal \\
\hline & & $\mathrm{p}-05$ & $A$ & $02 / 01 / 90$ & $5287: 06$ & & Normal \\
\hline & & $p-06$ & $A$ & $02 / 01 / 90$ & $5287: 07$ & & Normal \\
\hline & & P.07 & A & $02 / 01 / 90$ & 5287:08 & & Normal \\
\hline & & $p-08$ & A & $02 / 01 / 90$ & 5287:09 & & Normal \\
\hline & & $p-09$ & A & $02 / 01 / 90$ & $5287: 10$ & & $\begin{array}{l}\text { Particulates observed on } \\
\text { the annulus floor } \\
\text { appeared to be gilsulate } \\
\text { insulation. }\end{array}$ \\
\hline
\end{tabular}


TABLE 1

SUMMARY OF INSPECTIONS

\begin{tabular}{|c|c|c|c|c|c|c|c|}
\hline \multirow{7}{*}{$\frac{\text { Area }}{H}$} & \multirow{7}{*}{$\begin{array}{c}\begin{array}{c}\text { Tank } \\
\text { or } \\
\text { Vessel }\end{array} \\
38\end{array}$} & \multirow{3}{*}{$\begin{array}{l}\text { Inspec- } \\
\text { tion } \\
\text { Port } \\
p-10\end{array}$} & \multirow{3}{*}{$\begin{array}{l}\text { Annulus } \\
\text { or } \\
\text { Interior } \\
A\end{array}$} & \multirow{3}{*}{$\frac{\text { Date }}{02 / 01 / 90}$} & \multicolumn{2}{|c|}{$\begin{array}{l}\text { Type of Inspection and } \\
\text { Identification Numbers } \\
\end{array}$} & \multirow[b]{2}{*}{ Remarks } \\
\hline & & & & & \multirow{2}{*}{$\frac{\text { HAP }}{5287: 11}$} & $D P \quad P S P$ & \\
\hline & & & & & & & $\begin{array}{l}\text { Particulates observed on } \\
\text { the annulus floor } \\
\text { appeared to be gilsulate } \\
\text { insulation. }\end{array}$ \\
\hline & & $p-11$ & A & $02 / 01 / 90$ & $5287: 12$ & & Normal \\
\hline & & $p-12$ & A & $02 / 01 / 90$ & 5298:13 & & Normal \\
\hline & & $p-13$ & $A$ & $02 / 01 / 90$ & $5287: 14$ & & $\begin{array}{l}\text { Particulates observed on } \\
\text { the annulus floor } \\
\text { appeared to be gilsulate } \\
\text { insulation. }\end{array}$ \\
\hline & & $p-14$ & A & $02 / 01 / 90$ & $5287: 01$ & & Normal \\
\hline \multirow[t]{18}{*}{$H$} & 39 & A-01 & A & $02 / 01 / 90$ & & $5294: 01-25$ & Normal \\
\hline & & A-02 & A & $02 / 01 / 90$ & & $5295: 01-25$ & Normal \\
\hline & & A-03 & $A$ & $02 / 01 / 90$ & & 5296:01-25 & Normal \\
\hline & & A-04 & A & $02 / 01 / 90$ & & $5297: 01-25$ & Normal \\
\hline & & $\underline{p-01}$ & A & $02 / 01 / 90$ & $5288: 12$ & & Normal \\
\hline & & P-02 & $A$ & $02 / 01 / 90$ & $5288: 01$ & & Normal \\
\hline & & P.03 & A & $02 / 01 / 90$ & 5288:02 & & Normal \\
\hline & & $\mathrm{p}-04$ & A & $02 / 01 / 90$ & 5288:03 & & Hormal \\
\hline & & $p-05$ & A & $02 / 01 / 90$ & 5288:04 & & Normal \\
\hline & & P.06 & A & $02 / 01 / 90$ & 5288:05 & & Normal \\
\hline & & p-07 & $A$ & $02 / 01 / 90$ & 5288:06 & & Normal \\
\hline & & $p-08$ & A & $02 / 27 / 90$ & $5342: 01$ & & Normal \\
\hline & & p-09 & A & $02 / 01 / 90$ & 5288:08 & & Normal \\
\hline & & $P=10$ & A & $02 / 01 / 90$ & 5288:09 & & Normal \\
\hline & & $p-11$ & A & $02 / 01 / 90$ & 529\%:10 & & Normal \\
\hline & & $p-12$ & $A$ & $02 / 01 / 90$ & 5288:11 & & Normal \\
\hline & & $p=13$ & $A$ & $02 / 01 / 90$ & 5288:14 & & Normal \\
\hline & & $p-14$ & A & $02 / 01 / 90$ & $5288: 13$ & & Normal \\
\hline \multirow[t]{12}{*}{$H$} & 40 & $A-01$ & $A$ & $01 / 30 / 90$ & 5279:01 & & $\begin{array}{l}\text { Normal } \\
\text { Normal } \\
\end{array}$ \\
\hline & & $A-01$ & $A$ & $01 / 30 / 90$ & $5279: 02$ & & $\begin{array}{l}\text { Normal } \\
\text { Normal }\end{array}$ \\
\hline & & $A-02$ & A & $01 / 30 / 90$ & 5279:05 & & Normal \\
\hline & & A-03 & $A$ & $01 / 30 / 90$ & 5279:09 & & Normal \\
\hline & & A-04 & A & $01 / 30 / 90$ & $5279: 12$ & & Hormal \\
\hline & & $P-02 A$ & $A$ & $01 / 30 / 90$ & 5279:03 & & Normal \\
\hline & & $\mathrm{P}-03$ & A & $01 / 30 / 90$ & 5279:04 & & Normal \\
\hline & & P. 04 & A & $01 / 30 / 90$ & $5279: 06$ & & Normal \\
\hline & & P. 05 & A & $01 / 30 / 90$ & & $5280: 01-25$ & Normal \\
\hline & & p- 06 & A & $01 / 30 / 90$ & 5279:07 & & Normal \\
\hline & & p-07 & A & $01 / 30 / 90$ & 5279:08 & & Normal \\
\hline & & $p-08$ & $A$ & $01 / 30 / 90$ & & $5281: 01-25$ & Normal \\
\hline
\end{tabular}


TABLE 1

SUMMARY OF INSPECTIONS

\begin{tabular}{|c|c|c|c|c|c|c|c|}
\hline \multirow{3}{*}{$\frac{\text { Area }}{H}$} & \multirow{2}{*}{$\begin{array}{c}\text { Tank } \\
\text { or } \\
\text { Vessel } \\
\end{array}$} & \multirow{2}{*}{$\begin{array}{l}\text { Inspec- } \\
\text { tion } \\
\text { Port } \\
\end{array}$} & \multirow{2}{*}{$\begin{array}{l}\text { Annulus } \\
\text { or } \\
\text { Interior }\end{array}$} & \multirow[b]{2}{*}{ Date } & \multicolumn{2}{|c|}{$\begin{array}{l}\text { Type of Inspection and } \\
\text { Ident if ication Wumbers }\end{array}$} & \multirow[b]{2}{*}{ Remarks } \\
\hline & & & & & WAP & DP $\quad$ PSP & \\
\hline & & p.09 & $A$ & $01 / 30 / 90$ & $5279: 10$ & & Normal \\
\hline \multirow{5}{*}{$H$} & & $p-10$ & $A$ & $01 / 30 / 90$ & $5279: 11$ & & Normal \\
\hline & & $p-11$ & $A$ & $01 / 30 / 90$ & & 5282:01-25 & Normal \\
\hline & & $p-12$ & A & $01 / 30 / 90$ & $5279: 13$ & & Normal \\
\hline & & $p-13$ & A & $01 / 30 / 90$ & $5279: 14$ & & Normal \\
\hline & & $p-14$ & A & $01 / 30 / 90$ & & $5283: 01-25$ & Normal \\
\hline \multirow[t]{18}{*}{$H$} & 41 & A-OS & A & $02 / 09 / 90$ & & $5310: 01-25$ & Normal \\
\hline & & $A-02$ & A & $02 / 09 / 90$ & & $5312: 01-25$ & Normal \\
\hline & & $\mathrm{A}-03$ & $A$ & $02 / 09 / 90$ & & $5311: 01-25$ & Normal \\
\hline & & A-04 & $A$ & $02 / 09 / 90$ & & $5313: 01-25$ & Normal \\
\hline & & $p-01$ & A & $02 / 06 / 90$ & 5303:01 & & Normal \\
\hline & & $\mathrm{p}-02$ & $A$ & $02 / 06 / 90$ & $5303: 02$ & & Normal \\
\hline & & $\mathrm{p}-03$ & $A$ & $02 / 06 / 90$ & $5303: 03$ & & Normal \\
\hline & & p.04 & $A$ & $02 / 06 / 90$ & 5303:04 & & Normal \\
\hline & & $\mathrm{p}-05$ & A & $02 / 06 / 90$ & 5303:05 & & Normal \\
\hline & & $\mathrm{p}-06$ & $A$ & $02 / 06 / 90$ & $5303: 06$ & & Normal \\
\hline & & p.07 & A & $02 / 06 / 90$ & $5303: 07$ & & Normal \\
\hline & & $p-08$ & $A$ & $02 / 06 / 90$ & 5303:08 & & Normal \\
\hline & & p-09 & A & $02 / 06 / 90$ & $5303: 09$ & & Normal \\
\hline & & $p-10$ & A & $02 / 06 / 90$ & 5303:10 & & Normal \\
\hline & & $p-11$ & $A$ & $02 / 06 / 90$ & 5303:11 & & Normal \\
\hline & & $p-12$ & A & $02 / 06 / 90$ & $5303: 12$ & & Normal \\
\hline & & $p-13$ & A & $02 / 06 / 90$ & $5303: 13$ & & Normal \\
\hline & & $P-14$ & $A$ & $02 / 06 / 90$ & 5303:14 & & Normal \\
\hline \multirow[t]{18}{*}{$H$} & 42 & A-01 & $A$ & $01 / 30 / 90$ & $5286: 14$ & & Normal \\
\hline & & $\mathrm{A}-02$ & A & $01 / 30 / 90$ & $5286: 03$ & & Normal \\
\hline & & A-03 & $A$ & $02 / 01 / 90$ & & $5293: 01-25$ & Normal \\
\hline & & A-04 & A & $01 / 30 / 90$ & $5286: 10$ & & Normal \\
\hline & & $p-01$ & A & $01 / 30 / 90$ & 5286:01 & & Normal \\
\hline & & $\mathrm{p}-02$ & A & $01 / 30 / 90$ & $5286: 02$ & & Normal \\
\hline & & $p-03$ & $A$ & $02 / 06 / 90$ & & $5302: 01-25$ & Normal \\
\hline & & p-04 & $A$ & $01 / 30 / 90$ & $5284: 04$ & & Normal \\
\hline & & $p-05$ & A & $01 / 30 / 90$ & 5286:05 & & Normal \\
\hline & & $p-06$ & $A$ & $01 / 30 / 90$ & $5286: 06$ & & Normal \\
\hline & & $p-07$ & $A$ & $01 / 30 / 90$ & & $5284: 01-25$ & Normal \\
\hline & & $p-08$ & A & $01 / 30 / 90$ & $5286: 07$ & & Normal \\
\hline & & P-09 & A & $01 / 30 / 90$ & $5286: 08$ & & Normal \\
\hline & & $p-10$ & $A$ & $01 / 30 / 90$ & $5286: 09$ & & Normal \\
\hline & & $p-11$ & $A$ & $01 / 30 / 90$ & & $5285: 01-25$ & Normal \\
\hline & & $p-12$ & A & $01 / 30 / 90$ & 5286:11 & & Normal \\
\hline & & $p-13$ & A & $01 / 30 / 90$ & $5286: 12$ & & Normal \\
\hline & & $\mathrm{p}-14$ & $A$ & $01 / 30 / 90$ & 5286:13 & & Normal \\
\hline$H$ & 43 & $A-01$ & A & $02 / 09 / 90$ & & $5314: 01-25$ & $\begin{array}{l}\text { Gilsulate insulation on } \\
\text { the annulus floor had } \\
\text { been redistributed since } \\
\text { photographed on } 2-12-86 \text {. }\end{array}$ \\
\hline
\end{tabular}


TABLE 1

SUMMARY OF INSPECTIONS

\begin{tabular}{|c|c|c|c|c|c|c|c|}
\hline \multirow{2}{*}{ Area } & \multirow{2}{*}{$\begin{array}{c}\text { Tank } \\
\text { or } \\
\text { Vessel } \\
\end{array}$} & \multirow{2}{*}{$\begin{array}{l}\text { Inspec- } \\
\text { tion } \\
\text { Port } \\
\end{array}$} & \multirow{2}{*}{$\begin{array}{l}\text { Annulus } \\
\text { or } \\
\text { Interior }\end{array}$} & \multirow[b]{2}{*}{ Date } & \multicolumn{3}{|c|}{$\begin{array}{l}\text { Type of Inspection and } \\
\text { Identification Numbers }\end{array}$} \\
\hline & & & & & HAP & $D P$ & PSP \\
\hline & 43 & $\overline{A-01}$ & $A$ & $\overline{05 / 15 / 90}$ & $5504: 08$ & & \\
\hline
\end{tabular}

$\overline{A-02} \quad \mathrm{~A} \quad 02 / 09 / 90 \quad 5315: 01-25$

\begin{tabular}{lllll}
\hline A-02 & $A$ & $05 / 15 / 90$ & $5504: 05$ & \\
\hline$A-03$ & $A$ & $02 / 09 / 90$ & $5316: 01-25$
\end{tabular}

\begin{tabular}{lllll}
\hline$A-03$ & $A$ & $05 / 15 / 90$ & $5504: 16$ & \\
\hline$A-04$ & $A$ & $02 / 09 / 90$ & & $5317: 01-25$ \\
\hline$P-01$ & $A$ & $02 / 06 / 90$ & $5304: 01$ & \\
\hline$P-01$ & $A$ & $05 / 15 / 90$ & $5504: 07$ &
\end{tabular}

Remarks

Photographs were taken to document the current conditions in the annulus since flush water was inadvertently directed into the annulus on 5-10-90.

Gilsulate insulation on the annulus floor had been redistributed since photographed on 2-12-86. Normal

Gilsulate insulation on the annulus floor had been redistributed since photographed on 2-7-86. Normal Normal Normal

Photographs were taken to document the current conditions in the annulus since flush water was inadvertently directed into the annulus on 5-10-90.

\begin{tabular}{llll}
\hline P-02 & $A$ & $02 / 06 / 90$ & $5304: 02$ \\
\hline$P-02$ & $A$ & $05 / 15 / 90$ & $5504: 06$
\end{tabular}
mal

Photographs were taken to document the current donditions in the annulus since flush water was inadvertently directed into the annulus on 5-10-90.

\begin{tabular}{llllll}
\hline $\mathrm{P}-03$ & $A$ & $02 / 06 / 90$ & $5304: 03$ & Normal \\
\hline $\mathrm{P}-04$ & $A$ & $02 / 06 / 90$ & $5304: 04$ & Normal \\
\hline$p-04$ & $A$ & $05 / 15 / 90$ & $5504: 03$ & Normal \\
\hline$p-05$ & $A$ & $02 / 06 / 90$ & $5304: 05$ & Normal \\
\hline$p-05$ & $A$ & $05 / 15 / 90$ & $5504: 04$ & Normal \\
\hline$p-06$ & $A$ & $02 / 06 / 90$ & $5304: 06$ & Normal \\
\hline$p-06$ & $A$ & $05 / 15 / 90$ & $5504: 02$ & Normal \\
\hline$p-07$ & $A$ & $02 / 06 / 90$ & $5304: 07$ & Normal \\
\hline$p-07$ & $A$ & $05 / 15 / 90$ & $5504: 01$ & Normal \\
\hline
\end{tabular}


TABLE 1

SUMMARY OF INSPECTIONS

\begin{tabular}{|c|c|c|c|c|c|c|c|}
\hline \multirow[b]{2}{*}{ Area } & \multirow{2}{*}{$\begin{array}{c}\text { Tank } \\
\text { or } \\
\text { Vessel } \\
\end{array}$} & \multirow{2}{*}{$\begin{array}{l}\text { Inspec- } \\
\text { tion } \\
\text { Port }\end{array}$} & \multirow{2}{*}{$\begin{array}{l}\text { Annulus } \\
\text { or } \\
\text { Interior }\end{array}$} & \multirow[b]{2}{*}{ Date } & \multicolumn{3}{|c|}{$\begin{array}{l}\text { Type of Inspection and } \\
\text { Identification Numbers }\end{array}$} \\
\hline & & & & & MAP & $D P$ & PSP \\
\hline $\bar{H}$ & 43 & $p-08$ & $A$ & $02 / 06 / 90$ & $5304: 08$ & & \\
\hline & & P-08 & $A$ & $05 / 15 / 90$ & $5504: 15$ & & \\
\hline
\end{tabular}

\section{document the current}

conditions in the annulus

since flush water was

inadvertently directed

into the annulus on

5-10-90.

\begin{tabular}{lllll}
\hline P-09 & $A$ & $02 / 06 / 90$ & $5304: 09$ & P \\
\hline$P-09$ & $A$ & $05 / 15 / 90$ & $5504: 14$
\end{tabular}
Normal

Photographs were taken to document the current conditions in the annulus since flush water was inadvertently directed into the anmulus on : 5-10-90.

\begin{tabular}{lllll}
\hline$p-10$ & $A$ & $02 / 06 / 90$ & $5304: 10$ & Normal \\
\hline$P-10$ & $A$ & $05 / 15 / 90$ & $5504: 13$ & Photographs were taken to
\end{tabular}
document the current conditions in the annulus since flush water was inadvertently directed into the annulus on 5-10-90.

\begin{tabular}{|c|c|c|c|c|}
\hline p.11 & A & $02 / 06 / 90$ & $5304: 11$ & Normal \\
\hline$p-11$ & A & $05 / 15 / 90$ & $5504: 12$ & Photographs were taken to \\
\hline
\end{tabular}
document the current condition in the annulus since flush water was inodvertently directed into the annulus on 5-10-90.

\begin{tabular}{lllll}
\hline $\mathrm{p}-12$ & $A$ & $02 / 06 / 90$ & $5304: 12$ & Normal \\
\hline $\mathrm{P}-12$ & $A$ & $05 / 15 / 90$ & $5504: 11$ & Photographs were taken to
\end{tabular}
document the current conditions in the anmulus since flush water was inadvertently directed into the annulus on 5-10-90.

\begin{tabular}{|c|c|c|c|c|}
\hline$p-13$ & $A$ & $02 / 06 / 90$ & $5304: 13$ & Normal \\
\hline$p-13$ & A & $05 / 15 / 90$ & $5504: 10$ & $\begin{array}{l}\text { Photographs were taken to } \\
\text { document the current } \\
\text { conditions in the anmulus } \\
\text { since flush water was } \\
\text { inadvertently directed } \\
\text { into the annulus on }\end{array}$ \\
\hline
\end{tabular}

page 39 
TABLE 1

SUMMARY OF INSPECTIONS

\begin{tabular}{|c|c|c|c|c|c|c|c|}
\hline \multirow{5}{*}{$\frac{\text { Area }}{H}$} & \multirow{5}{*}{$\begin{array}{c}\text { Tank } \\
\text { or } \\
\text { Vessel } \\
43\end{array}$} & \multirow{2}{*}{$\begin{array}{l}\text { Inspec- } \\
\text { tion } \\
\text { Port } \\
\end{array}$} & \multirow{2}{*}{$\begin{array}{l}\text { Annulus } \\
\text { or } \\
\text { Interior }\end{array}$} & \multirow[b]{2}{*}{ Date } & \multicolumn{2}{|c|}{$\begin{array}{l}\text { Type of Inspection and } \\
\text { Identification Numbers }\end{array}$} & \multirow[b]{2}{*}{ Remarks } \\
\hline & & & & & WAP & DP $\quad P S P$ & \\
\hline & & $p-13$ & $A$ & $05 / 15 / 90$ & $5504: 10$ & & 5-10-90. \\
\hline & & $p-14$ & A & $02 / 06 / 90$ & $5304: 14$ & & Normal \\
\hline & & $\mathrm{p}-14$ & $A$ & $05 / 15 / 90$ & $5504: 09$ & & $\begin{array}{l}\text { Photographs were taken to } \\
\text { document the current } \\
\text { conditions in the annulus } \\
\text { since flush water was } \\
\text { indavertently directed } \\
\text { into the annulus on } \\
5-10-90 \text {. }\end{array}$ \\
\hline \multirow[t]{18}{*}{$\mathbf{F}$} & 44 & A-01 & A & $01 / 11 / 90$ & 5236:01 & & Normal \\
\hline & & A-02 & A & $01 / 11 / 90$ & 5236:06 & & Normal \\
\hline & & $A-03$ & $A$ & $01 / 11 / 90$ & $5236: 08$ & & $\begin{array}{l}\text { Stains and marks visible } \\
\text { in the annulus were } \\
\text { caused by the inleakage } \\
\text { of water. }\end{array}$ \\
\hline & & $A \cdot 04$ & A & $01 / 11 / 90$ & $5236: 12$ & & $\begin{array}{l}\text { Stains and marks visible } \\
\text { in the anmulus were } \\
\text { caused by the inleakage } \\
\text { of water. }\end{array}$ \\
\hline & & $\mathrm{P}-01$ & A & $01 / 11 / 90$ & & $5221: 01-25$ & Normal \\
\hline & & P-02 & A & $01 / 11 / 90$ & & 5222:01-25 & Normal \\
\hline & & $p-03$ & A & $01 / 11 / 90$ & 5236:02 & & Normal \\
\hline & & $\mathrm{p}-04$ & A & $01 / 11 / 90$ & $5236: 03$ & & Normal \\
\hline & & p.05 & A & $01 / 11 / 90$ & $5236: 04$ & & Normal \\
\hline & & $p-06$ & A & $01 / 11 / 90$ & $5236: 05$ & & Normal \\
\hline & & P-07 & A & $01 / 11 / 90$ & 5236:07 & & Normal \\
\hline & & $p-08$ & A & $01 / 11 / 90$ & & $5223: 01-25$ & $\begin{array}{l}\text { Stains and marks visible } \\
\text { in the annulus were } \\
\text { caused by the inleakage } \\
\text { of water. }\end{array}$ \\
\hline & & P.09 & A & $01 / 18 / 90$ & & $5256: 01-25$ & $\begin{array}{l}\text { Stains and marks visible } \\
\text { in the anmulus were } \\
\text { caused by the inleakage } \\
\text { of water. }\end{array}$ \\
\hline & & $p-10$ & A & $01 / 11 / 90$ & 5236:09 & & Normal \\
\hline & & $p-11$ & A & $01 / 11 / 90$ & $5236: 10$ & & Hormal \\
\hline & & $p-12$ & A & $01 / 11 / 90$ & 5236:11 & & Normal \\
\hline & & $p-13$ & A & $01 / 11 / 90$ & $5236: 13$ & & Normal \\
\hline & & $p-14$ & $\mathbf{A}$ & $01 / 11 / 90$ & 5236:14 & & Normal \\
\hline $\mathbf{F}$ & 45 & A-01 & A & $01 / 11 / 90$ & $5237: 01$ & & $\begin{array}{l}\text { Stains and marks visible } \\
\text { in the annulus were } \\
\text { caused by the inleakage } \\
\text { of water. }\end{array}$ \\
\hline
\end{tabular}


TABLE 1

SUMMARY OF INSPECTIONS

\begin{tabular}{|c|c|c|c|c|c|c|c|c|}
\hline \multirow[b]{2}{*}{ Area } & \multirow{2}{*}{$\begin{array}{c}\text { Tank } \\
\text { or } \\
\text { Vessel }\end{array}$} & \multirow{2}{*}{$\begin{array}{l}\text { Inspec- } \\
\text { tion } \\
\text { Port }\end{array}$} & \multirow{2}{*}{$\begin{array}{l}\text { Annulus } \\
\text { or } \\
\text { Interior }\end{array}$} & \multirow[b]{2}{*}{ Date } & \multicolumn{3}{|c|}{$\begin{array}{l}\text { Type of Inspection and } \\
\text { Identification Numbers }\end{array}$} & \multirow[b]{2}{*}{ Remarks } \\
\hline & & & & & MAP & $D P$ & PSP & \\
\hline \multirow[t]{18}{*}{$F$} & 45 & $A-02$ & $A$ & $01 / 11 / 90$ & $5237: 06$ & & & Normal \\
\hline & & $\mathrm{A-03}$ & $A$ & $01 / 11 / 90$ & 5237:08 & & & Normal \\
\hline & & A-04 & $A$ & $01 / 11 / 90$ & $5237: 12$ & & & Normal \\
\hline & & $\mathrm{p}-01$ & $A$ & $01 / 11 / 90$ & & $5224: 01-25$ & & $\begin{array}{l}\text { Stains and marks visible } \\
\text { in the annulus were } \\
\text { caused by the inleakage } \\
\text { of water. }\end{array}$ \\
\hline & & $p-01$ & $A$ & $01 / 31 / 90$ & & & VISUAL & $\begin{array}{l}\text { Visual inspection was } \\
\text { made to search for the } \\
\text { leakpath that allowed } \\
\text { rainwater to enter the } \\
\text { annulus. The inspection } \\
\text { was made with water } \\
\text { running into the valve } \\
\text { house sump drain for } 7 \text { - } \\
1 / 2 \text { hours. No leakage } \\
\text { into the annulus was } \\
\text { observed. }\end{array}$ \\
\hline & & $\overline{p-02}$ & A & $01 / 11 / 90$ & & $5225: 01-25$ & & $\begin{array}{l}\text { Stains and marks visible } \\
\text { in the annulus were } \\
\text { caused by the inleakage } \\
\text { of water. }\end{array}$ \\
\hline & & $p-03$ & A & $01 / 11 / 90$ & $5237: 02$ & & & $\begin{array}{l}\text { Water marks indicated } \\
\text { that the riser plug } \\
\text { gasket had allowed } \\
\text { rainwater to leak into } \\
\text { the annulus since } \\
\text { inspected on } 1 / 5 / 89 \text {. }\end{array}$ \\
\hline & & 0.04 & $A$ & $01 / 11 / 90$ & 5237:03 & & & Normal \\
\hline & & p-05 & $A$ & $01 / 11 / 90$ & 5237:04 & & & Normal \\
\hline & & $p-06$ & A & $01 / 11 / 90$ & 5237:05 & & & Normal \\
\hline & & p-07 & A & $01 / 11 / 90$ & 5237:07 & & & Normal \\
\hline & & $p-08$ & A & $01 / 11 / 90$ & & 5226:01-25 & & Normal \\
\hline & & p-09 & $A$ & $01 / 11 / 90$ & & $5227: 01-25$ & & Normal \\
\hline & & $p-10$ & A & $01 / 11 / 90$ & 5237:09 & & & Normal \\
\hline & & $p-11$ & A & $01 / 11 / 90$ & $5237: 10$ & & & Normal \\
\hline & & $p-12$ & A & $01 / 11 / 90$ & $5237: 11$ & & & Normal \\
\hline & & $p-13$ & $A$ & $01 / 11 / 90$ & $5237: 13$ & & & Normal \\
\hline & & $p-14$ & A & $01 / 11 / 90$ & $5237: 14$ & & & Normal \\
\hline \multirow[t]{4}{*}{$F$} & 46 & A-01 & A & $01 / 11 / 90$ & $5238: 01$ & & & Normal \\
\hline & & $\mathrm{A}-02$ & A & $01 / 11 / 90$ & $5238: 11$ & & & Normal \\
\hline & & $\mathrm{A-03}$ & $A$ & $01 / 11 / 90$ & 5238:08 & & & Normal \\
\hline & & A-04 & $A$ & $01 / 11 / 90$ & $5238: 04$ & & & Normal \\
\hline
\end{tabular}


TABLE 1

SUMMARY OF INSPECTIONS

\begin{tabular}{|c|c|c|c|c|c|c|c|c|}
\hline \multirow[b]{2}{*}{ Area } & \multirow{2}{*}{$\begin{array}{c}\text { Tank } \\
\text { or } \\
\text { Vessel }\end{array}$} & \multirow{2}{*}{$\begin{array}{l}\text { Inspec- } \\
\text { tion } \\
\text { Port } \\
\end{array}$} & \multirow{2}{*}{$\begin{array}{l}\text { Annulus } \\
\text { or } \\
\text { Interior }\end{array}$} & \multirow[b]{2}{*}{ Date } & \multicolumn{3}{|c|}{$\begin{array}{l}\text { Type of Inspection and } \\
\text { Identification Numbers }\end{array}$} & \multirow[b]{2}{*}{ Remarks } \\
\hline & & & & & MAP & $D P$ & PSP & \\
\hline \multirow[t]{14}{*}{$\bar{F}$} & 46 & $p-01$ & $A$ & $01 / 11 / 90$ & & $5228: 01-25$ & & Normal \\
\hline & & P-02 & $A$ & $01 / 11 / 90$ & & $5229: 01-25$ & & Normal \\
\hline & & $P-03$ & A & $01 / 11 / 90$ & $5238: 03$ & & & Normal \\
\hline & & P.04 & $A$ & $01 / 11 / 90$ & $5238: 05$ & & & Normal \\
\hline & & $\mathrm{p}-05$ & A & $01 / 11 / 90$ & $5238: 06$ & & & Normal \\
\hline & & $\mathrm{p}-06$ & A & $01 / 11 / 90$ & $5238: 07$ & & & Normal \\
\hline & & $p-07$ & A & $01 / 11 / 90$ & 5238:09 & & & Normal \\
\hline & & $P-08$ & A & $01 / 11 / 90$ & & $5230: 01-25$ & & $\begin{array}{l}\text { stains and marks visible } \\
\text { in the annulus were } \\
\text { caused by the inleakage } \\
\text { of water. }\end{array}$ \\
\hline & & P-09 & A & $01 / 11 / 90$ & & $5231: 01-25$ & & Normal \\
\hline & & $p-10$ & $A$ & $01 / 11 / 90$ & $5238: 10$ & & & Normal \\
\hline & & $\mathrm{p}-11$ & A & $01 / 11 / 90$ & 5238:12 & & & Normal \\
\hline & & $p-12$ & A & $01 / 11 / 90$ & $5238: 13$ & & & Normal \\
\hline & & $p-13$ & $A$ & $01 / 11 / 90$ & 5238: 14 & & & Normal \\
\hline & & $p-14$ & $A$ & $01 / 11 / 90$ & 5238:02 & & & Normal \\
\hline \multirow[t]{18}{*}{$F$} & 47 & A-01 & A & $01 / 11 / 90$ & $5239: 11$ & & & Normal \\
\hline & & A-02 & $A$ & $01 / 11 / 90$ & 5239:09 & & & Normal \\
\hline & & A-03 & A & $01 / 11 / 90$ & $5239: 06$ & & & Normal \\
\hline & & A-04 & $A$ & $01 / 11 / 90$ & 5239:01 & & & Normal \\
\hline & & $p-01$ & A & $01 / 11 / 90$ & & $5232: 01-25$ & & Normal \\
\hline & & $p-02$ & A & $01 / 11 / 90$ & & $5233: 01-25$ & & Normal \\
\hline & & $p-03$ & A & $01 / 11 / 90$ & $5239: 02$ & & & Normal \\
\hline & & p-04 & $A$ & $01 / 11 / 90$ & $5239: 03$ & & & Normal \\
\hline & & p.05 & A & $01 / 11 / 90$ & 5239:04 & & & Normal \\
\hline & & $p-06$ & A & $01 / 11 / 90$ & $5239: 05$ & & & Normal \\
\hline & & $p-07$ & A & $01 / 11 / 90$ & $5239: 07$ & & & Normal \\
\hline & & $p-08$ & $A$ & $01 / 11 / 90$ & & $5234: 01-25$ & & Normal \\
\hline & & p-09 & $A$ & $01 / 11 / 90$ & & $5235: 01-25$ & & Normal \\
\hline & & $p-10$ & A & $01 / 11 / 90$ & 5239:08 & & & Normal \\
\hline & & $p-11$ & A & $01 / 11 / 90$ & $5239: 10$ & & & Normal \\
\hline & & $p-12$ & $A$ & $01 / 11 / 90$ & $5239: 12$ & & & Normal \\
\hline & & $p-13$ & $A$ & $01 / 11 / 90$ & $5239: 13$ & & & Normal \\
\hline & & $p-14$ & A & $01 / 11 / 90$ & $5239: 14$ & & & Normal \\
\hline \multirow[t]{2}{*}{$H$} & 48 & A-01 & A & $02 / 27 / 90$ & $5343: 18$ & & & Normal \\
\hline & & $\overline{A-01}$ & $A$ & $10 / 19 / 90$ & & & VISUAL & $\begin{array}{l}\text { A test was conducted to } \\
\text { determine if any of the } \\
\text { failed cooling coils ( } 3 \text {, } \\
5,16 \text { or 18) leaked into } \\
\text { the annulus. Inspection } \\
\text { was made with water } \\
\text { valved to the failed } \\
\text { coils. No leakage into } \\
\text { the annulus was observed } \\
\text { from this riser. }\end{array}$ \\
\hline
\end{tabular}


TABLE 1

SUMMARY OF INSPECTIONS

\begin{tabular}{|c|c|c|c|c|c|c|c|c|}
\hline \multirow[b]{2}{*}{ Area } & \multirow{2}{*}{$\begin{array}{c}\text { Tank } \\
\text { or } \\
\text { Vessel } \\
\end{array}$} & \multirow{2}{*}{$\begin{array}{l}\text { Inspec- } \\
\text { tion } \\
\text { Port }\end{array}$} & \multirow{2}{*}{$\begin{array}{l}\text { Annulus } \\
\text { or } \\
\text { Interior }\end{array}$} & \multirow[b]{2}{*}{ Date } & \multicolumn{3}{|c|}{$\begin{array}{l}\text { Type of Inspection and } \\
\text { Identification Numbers }\end{array}$} & \multirow[b]{2}{*}{ Remarks } \\
\hline & & & & & WAP & $D P$ & PSP & \\
\hline \multirow[t]{7}{*}{$H$} & 48 & A-02 & A & $02 / 27 / 90$ & $5343: 05$ & & & Normal \\
\hline & & $A-02$ & $A$ & $10 / 19 / 90$ & & & VISUAL & $\begin{array}{l}\text { A test was conducted to } \\
\text { determine if any of the } \\
\text { failed cooling coils ( } 3 \text {, } \\
5,16 \text { or 18) leaked into } \\
\text { the annulus. Inspection } \\
\text { was made with water } \\
\text { valved to the failed } \\
\text { coils. No leakage into } \\
\text { the annulus was observed } \\
\text { from this riser. }\end{array}$ \\
\hline & & $A-03$ & A & $02 / 21 / 90$ & & $5340: 01-25$ & & $\begin{array}{l}\text { Stains and marks visible } \\
\text { on the tank wall indicat- } \\
\text { ed that water leaked into } \\
\text { the annulus. Tests will } \\
\text { be performed to identify } \\
\text { the source of the water. }\end{array}$ \\
\hline & & $A-03$ & A & $02 / 27 / 90$ & $5343: 09$ & & & $\begin{array}{l}\text { Stains and marks visible } \\
\text { on the tank wall indicat- } \\
\text { ed that water leaked into } \\
\text { the annulus. Tests will } \\
\text { be performed to identify } \\
\text { the source of the water. }\end{array}$ \\
\hline & & $A-03$ & A & $10 / 19 / 90$ & & & VISUAL & $\begin{array}{l}\text { A test was conducted to } \\
\text { determine if any of the } \\
\text { failed cooling coils ( } 3 \text {, } \\
5,16 \text { or 18) leaked into } \\
\text { the annulus. Inspection } \\
\text { was made with water } \\
\text { valved to the failed } \\
\text { coils. No leakage into } \\
\text { the annulus was observed } \\
\text { from this riser. }\end{array}$ \\
\hline & & $A-03$ & A & $12 / 13 / 90$ & & & $5735: 01-08$ & $\begin{array}{l}\text { Inspection from this } \\
\text { riser showed cooling coil } \\
5 \text { leaked into the } \\
\text { annulus. When coils } 3 \\
\text { and } 5 \text { were presurized to } \\
\text { approximately } 100 \text { psig. } \\
\text { There was no evidence } \\
\text { that coil } 3 \text { leaked into } \\
\text { the annulus. }\end{array}$ \\
\hline & & A-04 & A & $02 / 27 / 90$ & $5343: 14$ & & & Normal \\
\hline
\end{tabular}


TABLE 1

SUMMARY OF INSPECTIONS

\begin{tabular}{|c|c|c|c|c|c|c|c|}
\hline \multirow{2}{*}{ eq } & \multirow{2}{*}{$\begin{array}{c}\text { Tank } \\
\text { or } \\
\text { Vessel } \\
\end{array}$} & \multirow{2}{*}{$\begin{array}{l}\text { Inspec- } \\
\text { tion } \\
\text { Port } \\
\end{array}$} & \multirow{2}{*}{$\begin{array}{l}\text { Annulus } \\
\text { or } \\
\text { Interior }\end{array}$} & \multirow[b]{2}{*}{ Date } & \multicolumn{3}{|c|}{$\begin{array}{l}\text { Type of Inspection and } \\
\text { Identification Numbers }\end{array}$} \\
\hline & & & & & MAP & $D P$ & PSP \\
\hline 4 & 48 & $A-04$ & A & $10 / 19 / 90$ & & & VISUAL \\
\hline
\end{tabular}

$A$ test was conducted to determine if any of the failed cooling coils ( 3 , 5, 16 or 18) leaked into the annulus. Inspection was made with water valved to the failed coils. No leakage into the annulus was observed from this riser.

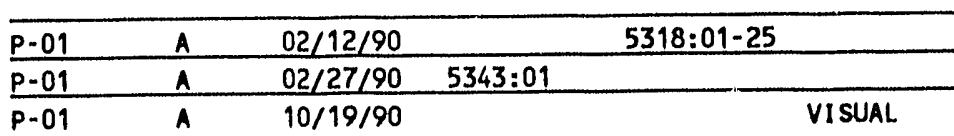
Normal Normal

A test was conducted to determine if any of the failed cooling coils $\times 3$, 5, 16 or 18) leaked into the annulus. Inspection was made with water valved to the failed coils. No leakage into the anmulus was observed from this riser.

\begin{tabular}{lllll}
\hline$p-02$ & $A$ & $02 / 12 / 90$ & $5319: 01-25$ & \\
\hline$p-02$ & $A$ & $02 / 27 / 90$ & $5343: 02$ & \\
\hline$p-02$ & $A$ & $10 / 19 / 90$ & & $5679: 01$
\end{tabular}
Normal Normal

A test was conducted to determine if any of the failed cooling coils (3, 5,16 or 18) leaked into the annulus. Inspection was made with water valved to the failed coils. No leakage into the anmulus was observed from this riser.

\begin{tabular}{lllll}
\hline $\mathrm{P}-03$ & A & $02 / 27 / 90$ & $5343: 03$ & \\
\hline $\mathrm{P}-03$ & $A$ & $10 / 19 / 90$ & & $5680: 01$
\end{tabular}
Normal

A test was conducted to determine if any of the failed cooling coils ( 3 , 5, 16 or 18) leaked into the annulus. Inspection was made with water valved to the failed coils. No leakage into the anmulus was observed from this riser. 
TABLE 1

SUMMARY OF INSPECTIONS

\begin{tabular}{|c|c|c|c|c|c|c|c|c|}
\hline \multirow[b]{2}{*}{ Area } & \multirow{2}{*}{$\begin{array}{c}\text { Tank } \\
\text { or } \\
\text { Vessel } \\
\end{array}$} & \multirow{2}{*}{$\begin{array}{l}\text { Inspec- } \\
\text { tion } \\
\text { Port } \\
\end{array}$} & \multirow{2}{*}{$\begin{array}{l}\text { Annulus } \\
\text { or } \\
\text { Interior }\end{array}$} & \multirow[b]{2}{*}{ Date } & \multicolumn{3}{|c|}{$\begin{array}{l}\text { Type of Inspection and } \\
\text { Identification Numbers }\end{array}$} & \multirow[b]{2}{*}{ Remarks } \\
\hline & & & & & HAP & $D P$ & PSP & \\
\hline \multirow[t]{8}{*}{ H } & & $\mathrm{p}-04$ & $A$ & $02 / 27 / 90$ & $5343: 04$ & & & Normal \\
\hline & & P-04 & $A$ & $10 / 19 / 90$ & & & $5681: 01$ & $\begin{array}{l}\text { A test was conducted to } \\
\text { determine if any of the } \\
\text { failed cooling coils ( } 3 \text {, } \\
5,16 \text { or 18) leaked into } \\
\text { the annulus. Inspection } \\
\text { was made with water valv- } \\
\text { ed to the failed coils. } \\
\text { No leakage into the } \\
\text { annulus was observed from } \\
\text { this riser. }\end{array}$ \\
\hline & & p-05 & A & $02 / 27 / 90$ & 5343:06 & & & Normal \\
\hline & & $P=05$ & A & $10 / 19 / 90$ & & & VISUAL. & $\begin{array}{l}\text { A test was conducted to } \\
\text { determine if any of the } \\
\text { failed cooling coils }(3 \text {, } \\
5,16 \text { or 18) leaked into } \\
\text { the annulus. Inspection } \\
\text { was made with water valv- } \\
\text { ed to the failed coils. } \\
\text { No leakage into the } \\
\text { annulus was observed from } \\
\text { this riser. }\end{array}$ \\
\hline & & P-06 & A & $02 / 21 / 90$ & & $5339: 01-25$ & . & $\begin{array}{l}\text { Stains and marks visible } \\
\text { on the tank wall indicat- } \\
\text { ed that water leaked into } \\
\text { the annulus. Tests will } \\
\text { be performed to identify } \\
\text { the source of the water. }\end{array}$ \\
\hline & & $\underline{\mathrm{P}-06}$ & A & $02 / 27 / 90$ & 5343:07 & & & Normal \\
\hline & & $P-06$ & $\wedge$ & $10 / 19 / 90$ & & & $5673: 01-02$ & $\begin{array}{l}\text { A test was conducted to } \\
\text { determine if any of the } \\
\text { failed cooling coils ( } 3 \text {, } \\
5,16 \text { or } 18 \text { ) leaked into } \\
\text { the annulus. Inspection } \\
\text { was made with water valv- } \\
\text { ed to the failed coils. } \\
\text { Leakage into the annulus } \\
\text { was observed from this } \\
\text { riser. }\end{array}$ \\
\hline & & $P-06$ & A & $\begin{array}{c}11 / 01 / 90 \\
.\end{array}$ & & & VISUAL & $\begin{array}{l}\text { Tests were conducted to } \\
\text { determine if any of the } \\
\text { failed cooling coils ( } 3 \text {, } \\
5,16 \text { or 18) leaked into } \\
\text { the annulus. Inspections } \\
\text { were made at risers P6, } \\
\text { P7 \& P14. The water was } \\
\text { valved on to cooling coil }\end{array}$ \\
\hline
\end{tabular}


TABLE 1

SUMMARY OF INSPECTIONS

\begin{tabular}{|c|c|c|c|c|c|c|c|c|}
\hline \multirow{5}{*}{$\frac{\text { Area }}{H}$} & \multirow{3}{*}{$\begin{array}{c}\text { Tank } \\
\text { or } \\
\text { Vessel }\end{array}$} & \multirow{3}{*}{$\begin{array}{l}\text { Inspec- } \\
\text { tion } \\
\text { Port } \\
\text { P-06 }\end{array}$} & \multirow{3}{*}{$\begin{array}{l}\text { Annulus } \\
\text { or } \\
\frac{\text { Interior }}{A}\end{array}$} & \multirow{3}{*}{$\frac{\text { Date }}{11 / 01 / 90}$} & \multicolumn{3}{|c|}{$\begin{array}{l}\text { Type of Inspection and } \\
\text { Identification Numbers }\end{array}$} & \multirow[b]{2}{*}{ Remarks } \\
\hline & & & & & WAP & $D P$ & PSP & \\
\hline & & & & & & & VISUAL & $\begin{array}{l}\text { \$3. No leakage was ob- } \\
\text { served. }\end{array}$ \\
\hline & & P.06 & $A$ & $11 / 02 / 90$ & & & VISUAL & $\begin{array}{l}\text { Inspections were made } \\
\text { with water valved off to } \\
\text { cool ing coil \#'s 3,5, } \\
16 \text { \& } 18 \text {. No leakage was } \\
\text { observed. }\end{array}$ \\
\hline & & $p-06$ & $A$ & $11 / 05 / 90$ & & & VISUAL & $\begin{array}{l}\text { Inspections were made } \\
\text { with water valved off to } \\
\text { cooling coil \#'s } 3,5 \text {, } \\
16 \text { \& } 18 \text {. No leakage Was } \\
\text { observed. }\end{array}$ \\
\hline & & $p-06$ & $A$ & $11 / 06 / 90$ & & & VISUAL & $\begin{array}{l}\text { Inspections were made } \\
\text { with water valved off to } \\
\text { cool ing coil \#'s 3,5: } \\
16 \text { \& } 18 \text {. No leakage was } \\
\text { oiserved. }\end{array}$ \\
\hline & & P-06 & A & $11 / 07 / 90$ & & & VISUAL & $\begin{array}{l}\text { Inspections were made } \\
\text { with water valved off to } \\
\text { all cooling coils. No } \\
\text { leakage was observed. }\end{array}$ \\
\hline & & p-06 & A & $11 / 08 / 90$ & & & VISUAL & $\begin{array}{l}\text { Inspections were made } \\
\text { with water valved off to } \\
\text { all cooling coils. No } \\
\text { leakage was observed. }\end{array}$ \\
\hline & & $p-07$ & $A$ & $02 / 21 / 90$ & & $5341: 01-25$ & & $\begin{array}{l}\text { Stains, marks, and wet } \\
\text { spots visible on the tank } \\
\text { wall indicated that water } \\
\text { leaked into the annulus. } \\
\text { Tests will be performed } \\
\text { to identify the source } \\
\text { of the water. }\end{array}$ \\
\hline & & $p-07$ & A & $02 / 27 / 90$ & $5343: 08$ & & & $\begin{array}{l}\text { Stains, marks, and wet } \\
\text { spots visible on the tank } \\
\text { wall indicated that water } \\
\text { leaked into the annulus. } \\
\text { Tests will be performed } \\
\text { to identify the source of } \\
\text { the water. }\end{array}$ \\
\hline & & P-07 & A & $03 / 02 / 90$ & & & $5356: 01-03$ & $\begin{array}{l}\text { Tests and inspections } \\
\text { were performed that } \\
\text { ult imately revealed that } \\
\text { cooling coil } 1 \text { was leak- } \\
\text { ing water into the } \\
\text { annulus. sixteen hours } \\
\text { after flow to the coil } \\
\text { was valved off, the wet }\end{array}$ \\
\hline
\end{tabular}


TABLE 1

SUMMARY OF INSPECTIONS

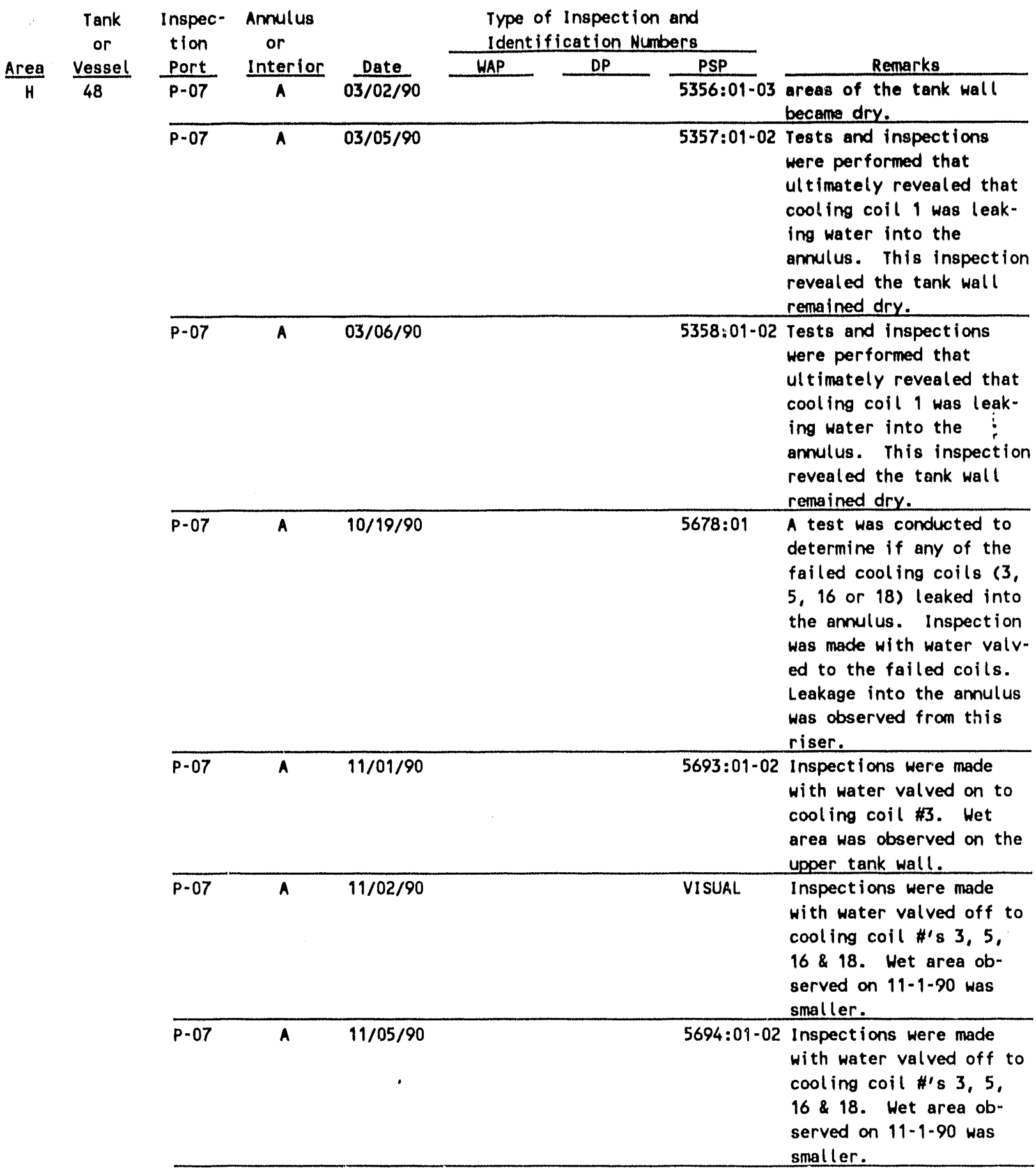


TABLE 1

SUMMARY OF INSPECTIONS

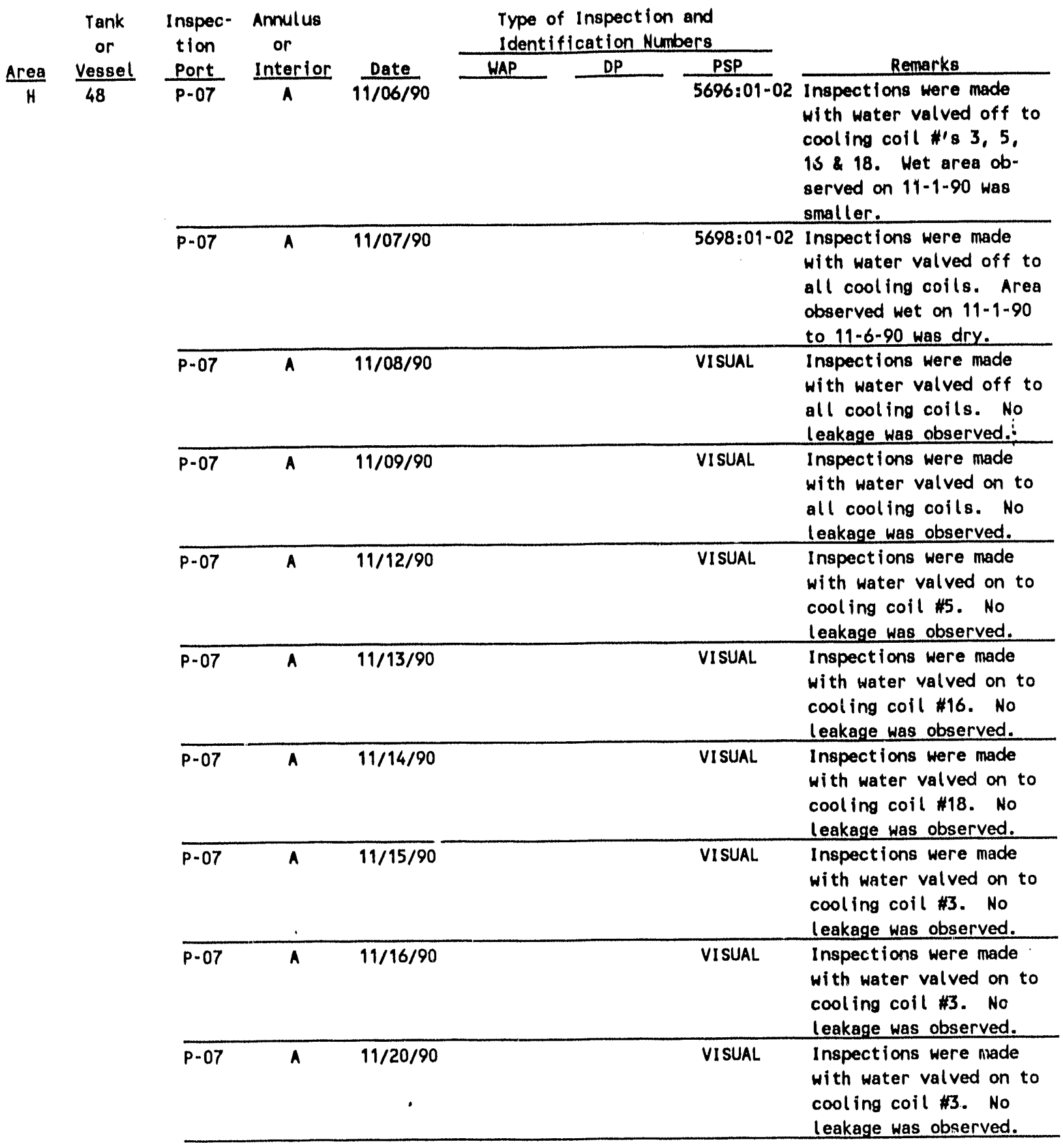


TABLE 1

SUMMARY OF INSPECTIONS

\begin{tabular}{|c|c|c|c|c|c|c|c|}
\hline \multirow[b]{2}{*}{ rea } & \multirow{2}{*}{$\begin{array}{c}\text { Tank } \\
\text { or } \\
\text { Vessel }\end{array}$} & \multirow{2}{*}{$\begin{array}{l}\text { Inspec- } \\
\text { tion } \\
\text { Port }\end{array}$} & \multirow{2}{*}{$\begin{array}{l}\text { Annulus } \\
\text { or } \\
\text { Interior }\end{array}$} & \multirow[b]{2}{*}{ Date } & \multicolumn{3}{|c|}{$\begin{array}{l}\text { Type of Inspection and } \\
\text { Ident if Ication Numbers }\end{array}$} \\
\hline & & & & & WAP & $D P$ & PSP \\
\hline H & 48 & P-07 & $A$ & $11 / 21 / 90$ & & & VISUAL \\
\hline
\end{tabular}

Inspections were made with water valved on to cooling coil \#'s 3, 5, 16 \& 18. No leakage was observed.

\begin{tabular}{|c|c|c|c|c|}
\hline$p-07$ & $A$ & $11 / 26 / 90$ & VISUAL & $\begin{array}{l}\text { Inspections were made } \\
\text { with water valved on to } \\
\text { cooling coil "'s } 3,5 \text {, } \\
16 \text { \& } 18 \text {. No leakage was } \\
\text { observed. }\end{array}$ \\
\hline$P-07$ & $A$ & $12 / 13 / 90$ & VISUAL. & No leakage into the \\
\hline
\end{tabular}
this riser when cooling coils 3 and 5 were pres. surized to approximaty 100 psig.

\begin{tabular}{lll}
\hline P-08 & A & $02 / 12 / 90$
\end{tabular}
Stains, marks, and wet spots visible on the tank wall indicated that water leaked into the annulus. Tests will be performed to identify the source of the water.

\begin{tabular}{llll}
\hline $\mathrm{P}-08$ & A & $02 / 21 / 90$ & $5338: 01-05$ \\
\hline $\mathrm{P}-08$ & A & $02 / 27 / 90$ & $5343: 10$
\end{tabular}

Tank wall had dried since inspection of 2-12-90. stains and marks visible on the tank wall indicated that water leaked into the annulus. Tests will be performed to identify the source of the water.

P-08 A 03/01/90 5349:01-07 Tests and inspections
were performed that ultimately revealed that cooling coil 1 was leaking water into the annulus. A few hours after flow to the coil was valved off, the wet areas of the tank wall became dry.

\begin{tabular}{|c|c|c|c|}
\hline$D-08$ & $03 / 02 / 90$ & $5370: 01-04$ & $\begin{array}{l}\text { Tests and inspections } \\
\text { were performed that } \\
\text { ultimately revealed that } \\
\text { ccoling coil } 1 \text { was leak- } \\
\text { ing water into the } \\
\text { annulus. A few hours }\end{array}$ \\
\hline
\end{tabular}


TABLE 1

SUMMARY OF INSPECTIONS

\begin{tabular}{|c|c|c|c|c|c|c|c|c|}
\hline & \multirow{2}{*}{$\begin{array}{c}\text { Tank } \\
\text { or } \\
\text { Vessel }\end{array}$} & \multirow{2}{*}{$\begin{array}{l}\text { Inspec- } \\
\text { tion } \\
\text { Port } \\
\text { P-08 }\end{array}$} & \multirow{2}{*}{$\begin{array}{l}\text { Annulus } \\
\text { or } \\
\text { Interior } \\
A\end{array}$} & \multirow{3}{*}{$\frac{\text { Date }}{03 / 02 / 90}$} & \multicolumn{3}{|c|}{$\begin{array}{l}\text { Type of Inspection and } \\
\text { Identification Numbers }\end{array}$} & \multirow[b]{2}{*}{ Remarks } \\
\hline & & & & & WAP & $D P$ & PSP & \\
\hline $\bar{H}$ & 48 & $p-08$ & $A$ & & & & 5370:01-04 & $\begin{array}{l}\text { after flow to the coll } \\
\text { was valved off, the wet } \\
\text { areas of the tank wall } \\
\text { became dry. }\end{array}$ \\
\hline & & $p-08$ & $A$ & $03 / 05 / 90$ & & & 5371:01-05 & $\begin{array}{l}\text { Tests and inspections } \\
\text { were performed that } \\
\text { ult imately revealed that } \\
\text { cooling coil } 1 \text { was leak- } \\
\text { ing water into the } \\
\text { annulus. A few hours } \\
\text { after flow to the coill } \\
\text { was valved off, the wet } \\
\text { areas of the tank wall } \\
\text { became dry. }\end{array}$ \\
\hline & & $P-08$ & $A$ & $03 / 06 / 90$ & & & $5372: 01-05$ & $\begin{array}{l}\text { Tests and inspections: } \\
\text { were performed that } \\
\text { ultimately revealed that } \\
\text { cooling coil } 1 \text { was leak- } \\
\text { ing water into the } \\
\text { annulus. A few hours } \\
\text { after flow to the coil } \\
\text { was valved off, the wet } \\
\text { areas of the tank wall } \\
\text { became dry. }\end{array}$ \\
\hline & & $p-08$ & A & $10 / 19 / 90$ & & & VISUAL & $\begin{array}{l}\text { A test was conducted to } \\
\text { determine if any of the } \\
\text { failed cool ing coils ( } 3 \text {, } \\
5,16 \text { or } 18 \text { ) leaked into } \\
\text { the annulus. Inspection } \\
\text { was made with water valv- } \\
\text { ed to the failed coils. } \\
\text { No leakage into the } \\
\text { annulus was observed from } \\
\text { this riser. }\end{array}$ \\
\hline & & P.09 & $A$ & $02 / 12 / 90$ & & $5321: 01-25$ & & $\begin{array}{l}\text { Stains and marks visible } \\
\text { on the tank wall indicat- } \\
\text { ed that water leaked into } \\
\text { the annulus. Tests will } \\
\text { be performed to identify } \\
\text { the source of the water. }\end{array}$ \\
\hline & & p-09 & A & $02 / 27 / 90$ & $5343: 11$ & & & $\begin{array}{l}\text { Stains and marks visible } \\
\text { on the tank wall indicat" } \\
\text { ed that water leaked into } \\
\text { the annulus. Tests will } \\
\text { be performed to identify } \\
\text { the source of the water. }\end{array}$ \\
\hline
\end{tabular}


TABLE 1

SUMMARY OF INSPECTIONS

\begin{tabular}{|c|c|c|c|c|c|c|c|}
\hline \multirow[b]{2}{*}{ Area } & \multirow{2}{*}{$\begin{array}{c}\text { Tank } \\
\text { or } \\
\text { Vessel }\end{array}$} & \multirow{2}{*}{$\begin{array}{l}\text { Inspec- } \\
\text { tion } \\
\text { Port }\end{array}$} & \multirow{2}{*}{$\begin{array}{l}\text { Annulus } \\
\text { or } \\
\text { Interior }\end{array}$} & \multirow[b]{2}{*}{ Date } & \multicolumn{3}{|c|}{$\begin{array}{l}\text { Type of Inspection and } \\
\text { Ident if ication Numbers }\end{array}$} \\
\hline & & & & & WAP & $D P$ & PSP \\
\hline H & 48 & $p .09$ & $A$ & $10 / 19 / 90$ & & & VISUAL. \\
\hline
\end{tabular}

Remarks

A test was conchucted to determine if any of the failed cooling coils ( 3 , 5. 16 or 18) leaked into the annulus. Inspection was made with water valved to the failed coils. No leakage into the annulus was observed from this riser.

\begin{tabular}{lll}
\hline$p-10$ & $A$ & $02 / 27 / 90$ \\
\hline$p-10$ & $A$ & $10 / 19 / 90$
\end{tabular}

$5343: 12$ Normal

VISUAL

A test was conducted to determine if any of the failed cooling coils (3, 5. 16 or 18) leaked into the annulus. Inspection was made with water valved to the failed coils. No leakage into the annulus was observed from this riser.

\begin{tabular}{lllll}
\hline$p-11$ & $A$ & $02 / 27 / 90$ & $5343: 13$ & \\
\hline$P-11$ & $A$ & $10 / 19 / 90$ & & VISUAL
\end{tabular}
Normal

A test was conducted to determine if any of the failed cooling coils (3, 5,16 or 18 ) leaked into the annulus. Inspection was made with water valved to the failed coils. No leakage into the annulus was observed from this riser.

\begin{tabular}{lllll}
\hline$p-12$ & $A$ & $02 / 27 / 90$ & $5343: 15$ & \\
\hline$P-12$ & $A$ & $10 / 19 / 90$ & & VISUAL.
\end{tabular}
Normal

A test was conducted to determine if any of the failed cooling coils (3, 5,16 or 18) leaked into the annulus. Inspection was made with water valved to the failed coils. No leakage into the annulus was observed from this riser. 
TABLE 1

SUMMARY OF INSPECTIONS

\begin{tabular}{|c|c|c|c|c|c|c|c|}
\hline \multirow{2}{*}{ Area } & \multirow{2}{*}{$\begin{array}{c}\text { Tank } \\
\text { or } \\
\text { Vessel } \\
\end{array}$} & \multirow{2}{*}{$\begin{array}{l}\text { Inspec- } \\
\text { tion } \\
\text { port }\end{array}$} & \multirow{2}{*}{$\begin{array}{l}\text { Annulus } \\
\text { or } \\
\text { Interior }\end{array}$} & \multirow[b]{2}{*}{ Date } & \multicolumn{3}{|c|}{$\begin{array}{l}\text { Type of Inspection and } \\
\text { Identification Numbers }\end{array}$} \\
\hline & & & & & HAP & $D P$ & PSP \\
\hline $\bar{H}$ & 48 & $p-13$ & $A$ & $02 / 27 / 90$ & $5343: 16$ & & \\
\hline & & $p-13$ & $A$ & $10 / 19 / 90$ & & & VISUAL \\
\hline
\end{tabular}

$\frac{\text { Remarks }}{\text { Normal }}$
determine if any of the failed cooling coils (3, 5,16 or 18) leaked into the annulus. Inspection was made with water valved to the failed coils. No leakage into the anmulus was observed from this riser.

\begin{tabular}{lllll}
\hline$p-14$ & $A$ & $02 / 27 / 90$ & $5343: 17$ & \\
\hline$p-14$ & $A$ & $11 / 01 / 90$ & VISUAL \\
\hline p-14 & A & $11 / 02 / 90$ & VIGUAL
\end{tabular}
Normal Inspections were made with water valved on to cooling coil \#3. No: leakage was observed. Inspections were made with water valved off to cooling coil \#'s 3, 5, $16 \& 18$. Ho leakage was observed.

\begin{tabular}{|c|c|c|c|c|}
\hline$p-14$ & $A$ & $11 / 05 / 90$ & $5695: 01-03$ & $\begin{array}{l}\text { Inspections were made } \\
\text { with water valved off to } \\
\text { cool ing coil \#'s 3,5, } \\
16 \text { \& } 18 \text {. Wet area was } \\
\text { observed on upper tank } \\
\text { wall. }\end{array}$ \\
\hline$p-14$ & $A$ & $11 / 06 / 90$ & $5897: 01-02$ & $\begin{array}{l}\text { Inspections were made } \\
\text { with water valved off to } \\
\text { cooling coil \#'s } 3,5 \text {, } \\
16 \text { \& } 18 \text {. Wet area ob- } \\
\text { served } 11-5-90 \text { was small- } \\
\text { er. }\end{array}$ \\
\hline$p-14$ & $A$ & $11 / 07 / 90$ & 5699:01-02 & $\begin{array}{l}\text { Inspections were made } \\
\text { with water valved off to } \\
\text { all cooling coils. Area } \\
\text { observed wet on } 11-5-90 \\
\text { and } 11-6-90 \text { was dry. }\end{array}$ \\
\hline$P-14$ & $A$ & $11 / 0 \varepsilon^{\prime} 90$ & VISUAL & $\begin{array}{l}\text { Inspections were made } \\
\text { with water valved off to } \\
\text { all cooling coils. No } \\
\text { leakage was observed. }\end{array}$ \\
\hline$P-14$ & $A$ & $11 / 09 / 90$ & VISUAL. & $\begin{array}{l}\text { Inspections were made } \\
\text { with water valved on to } \\
\text { all cooling coils. No } \\
\text { leakage was observed. }\end{array}$ \\
\hline
\end{tabular}


TABLE 1

SUMMARY OF INSPECTIONS

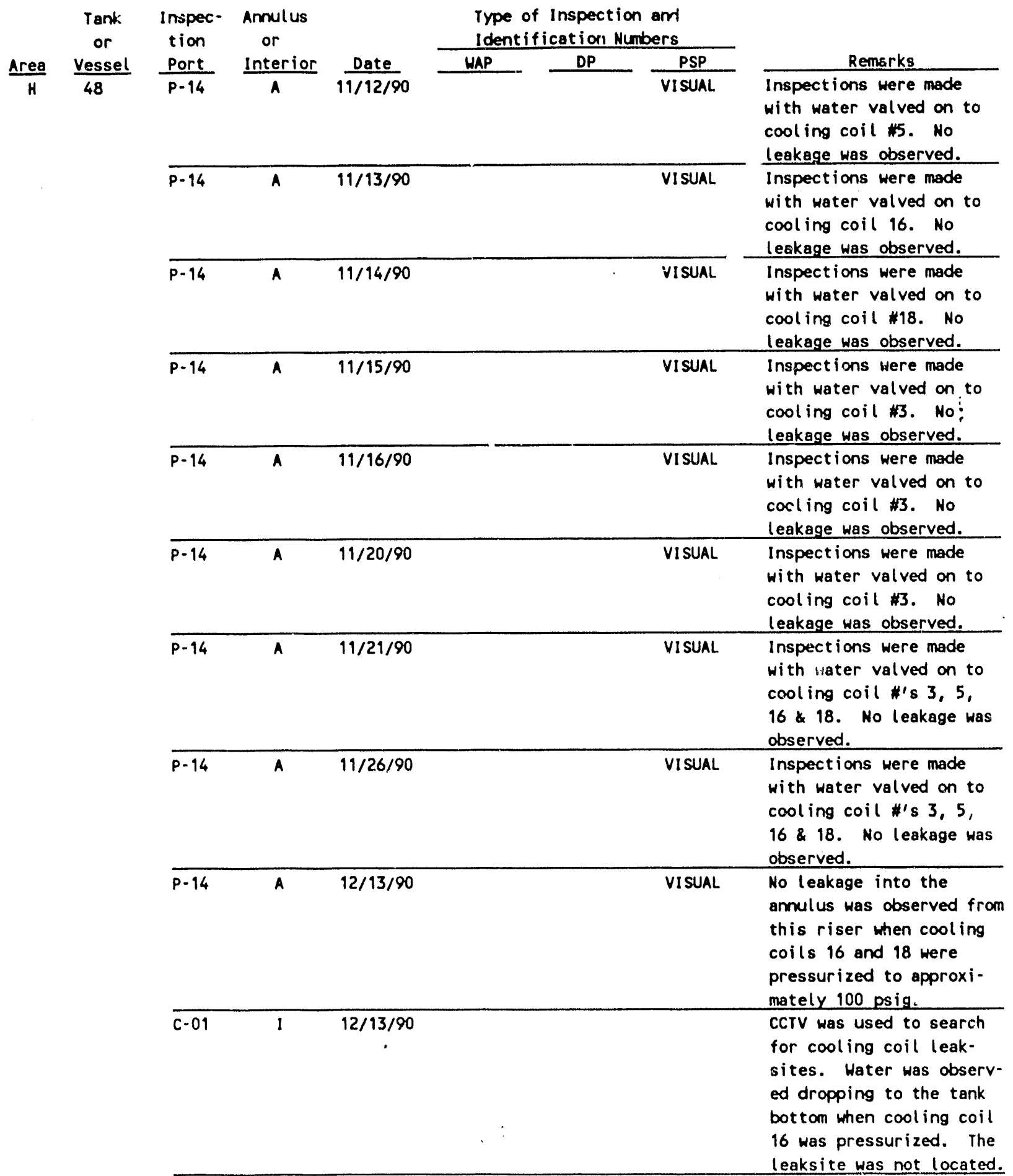


TABLE 1

SUMMARY OF INSPECTIONS

\begin{tabular}{|c|c|c|c|c|c|c|c|}
\hline \multirow[b]{2}{*}{ rea } & \multirow{2}{*}{$\begin{array}{c}\text { Tank } \\
\text { or } \\
\text { Vessel }\end{array}$} & \multirow{2}{*}{$\begin{array}{c}\text { Inspec- } \\
\text { tion } \\
\text { Port } \\
\end{array}$} & \multirow{2}{*}{$\begin{array}{l}\text { Annulus } \\
\text { or } \\
\text { Interior }\end{array}$} & \multirow[b]{2}{*}{ Date } & \multicolumn{3}{|c|}{$\begin{array}{l}\text { Type of Inspection and } \\
\text { Identification Numbers }\end{array}$} \\
\hline & & & & & WAP & $D P$ & PSP \\
\hline H & 48 & C.03 & I & $10 / 04 / 90$ & & & 01 \\
\hline
\end{tabular}

Identification Numbers

662:01-77 Steel surfaces of the tank interior and the cooling coils were inspected. No evidence of unusual corrosion was observed. C.F. Jenkins and D.T. Hobbs of SRL participated in the inspection.

C.03 I $12 / 13 / 90$

\begin{tabular}{|c|c|c|c|c|c|c|c|}
\hline \multirow[t]{18}{*}{$H$} & 49 & A-01 & A & $03 / 05 / 90$ & 5369:01 & & Normal \\
\hline & & A-02 & A & $03 / 05 / 90$ & 5369:03 & & Normal \\
\hline & & A-03 & A & $03 / 05 / 90$ & 5369:07 & & Normal \\
\hline & & A-04 & A & $03 / 21 / 90$ & 5402:06 & & Normal \\
\hline & & $\mathrm{P}-01$ & A & $02 / 20 / 90$ & & 5336:01-25 & Normal \\
\hline & & P-02 & A & $02 / 12 / 90$ & & $5322: 01-25$ & Normal \\
\hline & & p.03 & A & $03 / 21 / 90$ & 5402:05 & & Normal \\
\hline & & $\mathrm{P}-04$ & A & $03 / 05 / 90$ & $5369: 02$ & & Normal \\
\hline & & $p-05$ & A & $03 / 05 / 90$ & 5369:04 & & Normal \\
\hline & & $p-06$ & A & $03 / 05 / 90$ & $5309: 05$ & & Normal \\
\hline & & $\mathrm{p}-07$ & A & $03 / 05 / 90$ & $5369: 06$ & & Normal \\
\hline & & P-08 & A & $02 / 20 / 90$ & & $5337: 01-25$ & Normal \\
\hline & & p-09 & A & $02 / 12 / 90$ & & $5323: 01-25$ & Normal \\
\hline & & $p-10$ & $A$ & $03 / 05 / 90$ & $5369: 08$ & & Normal \\
\hline & & $p-11$ & $A$ & $03 / 21 / 90$ & 5402:04 & & Normal \\
\hline & & $p-12$ & $A$ & $03 / 21 / 90$ & 5402:03 & & Normal \\
\hline & & $\mathrm{p}-13$ & A & $03 / 21 / 90$ & $5402: 02$ & & Normal \\
\hline & & $\mathrm{p}-14$ & A & $03 / 21 / 90$ & 5402:01 & & Normal \\
\hline \multirow[t]{5}{*}{$H$} & 50 & A-01 & $A$ & $03 / 05 / 90$ & 5350:01 & & Normal \\
\hline & & $\mathrm{A-02}$ & A & $03 / 05 / 90$ & 5350:04 & & Normal \\
\hline & & $A-03$ & $A$ & $03 / 05 / 90$ & $5350: 11$ & & $\begin{array}{l}\text { Stains and marks on the } \\
\text { tank wall were caused by } \\
\text { the inleakage of water. }\end{array}$ \\
\hline & & A-04 & $A$ & $03 / 05 / 90$ & $5350: 11$ & & Normal \\
\hline & & p-01 & $A$ & $02 / 14 / 90$ & & $5324: 01-25$ & $\begin{array}{l}\text { The condition of the tank } \\
\text { wall and annulus was } \\
\text { normal. The screen was } \\
\text { missing from suction leg } \\
\text { of the annulus jet in- } \\
\text { stalled in the f riser. }\end{array}$ \\
\hline
\end{tabular}

CCTV was used to search for couling coil leaksites. Water was observed dropping to the tank bottom when cooling coil 3 was pressurized. Thie leaksite was not located. Norma 
TABLE 1

SUMMARY OF INSPECTIONS

\begin{tabular}{|c|c|c|c|c|c|c|c|}
\hline \multirow[b]{2}{*}{ Area } & \multirow{2}{*}{$\begin{array}{c}\text { Tank } \\
\text { or } \\
\text { Vessel } \\
\end{array}$} & \multirow{2}{*}{$\begin{array}{l}\text { Inspec- } \\
\text { tion } \\
\text { Port } \\
\end{array}$} & \multirow{2}{*}{$\begin{array}{l}\text { Annulus } \\
\text { or } \\
\text { Interior }\end{array}$} & \multirow[b]{2}{*}{ Date } & \multicolumn{2}{|c|}{$\begin{array}{l}\text { Type of Inspection and } \\
\text { Identification Numbers }\end{array}$} & \multirow[b]{2}{*}{ Remarks } \\
\hline & & & & & WAP & DP $\quad P S P$ & \\
\hline \multirow[t]{14}{*}{ H } & & $p-02$ & $A$ & $02 / 14 / 90$ & & $5325: 01-25$ & Normal \\
\hline & & $p-03$ & $A$ & $03 / 05 / 90$ & 5350:02 & & Normal \\
\hline & & $\mathrm{p}-04$ & $A$ & $03 / 05 / 90$ & $5350: 03$ & & Normal \\
\hline & & P-05 & $A$ & $03 / 05 / 90$ & $5350: 05$ & & $\begin{array}{l}\text { Stains and marks on the } \\
\text { tank wall were caused by } \\
\text { the inleakage of water. }\end{array}$ \\
\hline & & p-05 & A & $04 / 05 / 90$ & $5431: 01$ & & Normal \\
\hline & & P-06 & A & $03 / 05 / 90$ & $5350: 06$ & & Normal \\
\hline & & p-07 & A & $03 / 05 / 90$ & $5350: 07$ & & Normal \\
\hline & & P. 08 & $A$ & $02 / 14 / 90$ & & $5326: 01-25$ & Normal \\
\hline & & p-09 & $A$ & $02 / 14 / 90$ & & $5327: 01-25$ & $\begin{array}{l}\text { Stains and marks visible } \\
\text { in the annulus on the } \\
\text { tank wall caused by the } \\
\text { inleakage of water. }\end{array}$ \\
\hline & & $p-10$ & A & $03 / 05 / 90$ & $5350: 09$ & & Normal $\quad:$ \\
\hline & & $p-11$ & $A$ & $03 / 05 / 90$ & $5350: 10$ & & Normal \\
\hline & & $p-12$ & $A$ & $03 / 05 / 90$ & $5350: 12$ & & Normal \\
\hline & & $p-13$ & A & $03 / 05 / 90$ & $5350: 13$ & & Normal \\
\hline & & $p-14$ & A & $03 / 05 / 90$ & $5350: 14$ & & Normal \\
\hline \multirow[t]{18}{*}{$H$} & 51 & A-01 & A & $03 / 05 / 90$ & $5351: 02$ & & Normal \\
\hline & & A-02 & $A$ & $03 / 05 / 90$ & $5351: 05$ & & Normal \\
\hline & & A-03 & A & $03 / 05 / 90$ & $5351: 08$ & & Normal \\
\hline & & A-04 & $A$ & $03 / 05 / 90$ & $5351: 12$ & & Normal \\
\hline & & P-01 & $A$ & $02 / 14 / 90$ & & $5328: 01-25$ & $\begin{array}{l}\text { Stains and marks visible } \\
\text { in the annulus on the } \\
\text { floor caused by the in- } \\
\text { leakage of water. }\end{array}$ \\
\hline & & $P-02$ & $A$ & $02 / 14 / 90$ & & $5329: 01-25$ & $\begin{array}{l}\text { Stains and marks visible } \\
\text { in the annulus on the } \\
\text { floor caused by the in- } \\
\text { leakage of water. }\end{array}$ \\
\hline & & $p-03$ & A & $03 / 05 / 90$ & 5351:03 & & Normal \\
\hline & & $P-04$ & A & $03 / 05 / 90$ & $5351: 04$ & & Normal \\
\hline & & $p-05$ & A & $03 / 05 / 90$ & $5351: 06$ & & Normal \\
\hline & & $\mathrm{P}-06$ & A & $03 / 05 / 90$ & 5351:07 & & Hormal \\
\hline & & $p-07$ & $A$ & $03 / 05 / 90$ & $5351: 08$ & & Normal \\
\hline & & $p-08$ & $A$ & $02 / 14 / 90$ & & $5330: 01-25$ & Normal \\
\hline & & P-09 & A & $02 / 14 / 90$ & & $5331: 01-25$ & Normal \\
\hline & & $p-10$ & A & $03 / 05 / 90$ & $5351: 10$ & & Normal \\
\hline & & $p-11$ & $A$ & $03 / 05 / 90$ & $5351: 11$ & & Normal \\
\hline & & $p-12$ & A & $03 / 05 / 90$ & $5351: 13$ & & Normal \\
\hline & & $p-13$ & A & $03 / 05 / 90$ & $5351: 14$ & & Normal \\
\hline & & $p-14$ & $A$ & $03 / 05 / 90$ & $5351: 01$ & & Normal \\
\hline
\end{tabular}


TABLE 1

SUMMARY OF INSPECTIONS

\begin{tabular}{|c|c|c|c|c|c|c|c|}
\hline \multirow[b]{2}{*}{$\frac{\text { Area }}{H}$} & \multirow{2}{*}{$\begin{array}{c}\text { Tank } \\
\text { or } \\
\text { Vessel } \\
\end{array}$} & \multirow{2}{*}{$\begin{array}{l}\text { Inspec- } \\
\text { tion } \\
\text { Port } \\
\end{array}$} & \multirow{2}{*}{$\begin{array}{l}\text { Annulus } \\
\text { or } \\
\text { Interior } \\
\end{array}$} & \multirow[b]{2}{*}{$\frac{\text { Date }}{12 / 17 / 90}$} & \multicolumn{3}{|c|}{$\begin{array}{l}\text { Type of Inspection and } \\
\text { Identification Numbers }\end{array}$} \\
\hline & & & & & WAP & DP & PSP \\
\hline
\end{tabular}

AP

$$
\frac{12 / 17 / 90}{120}
$$

Remarks

Since direct viewing was not possible, CCTV was used to provide visual imagery needed for QA verification of the ITP Filter No. 1 tubes to shell sheets welds. Per M. L. Blake and H. D. McMull in the welds met requirements.

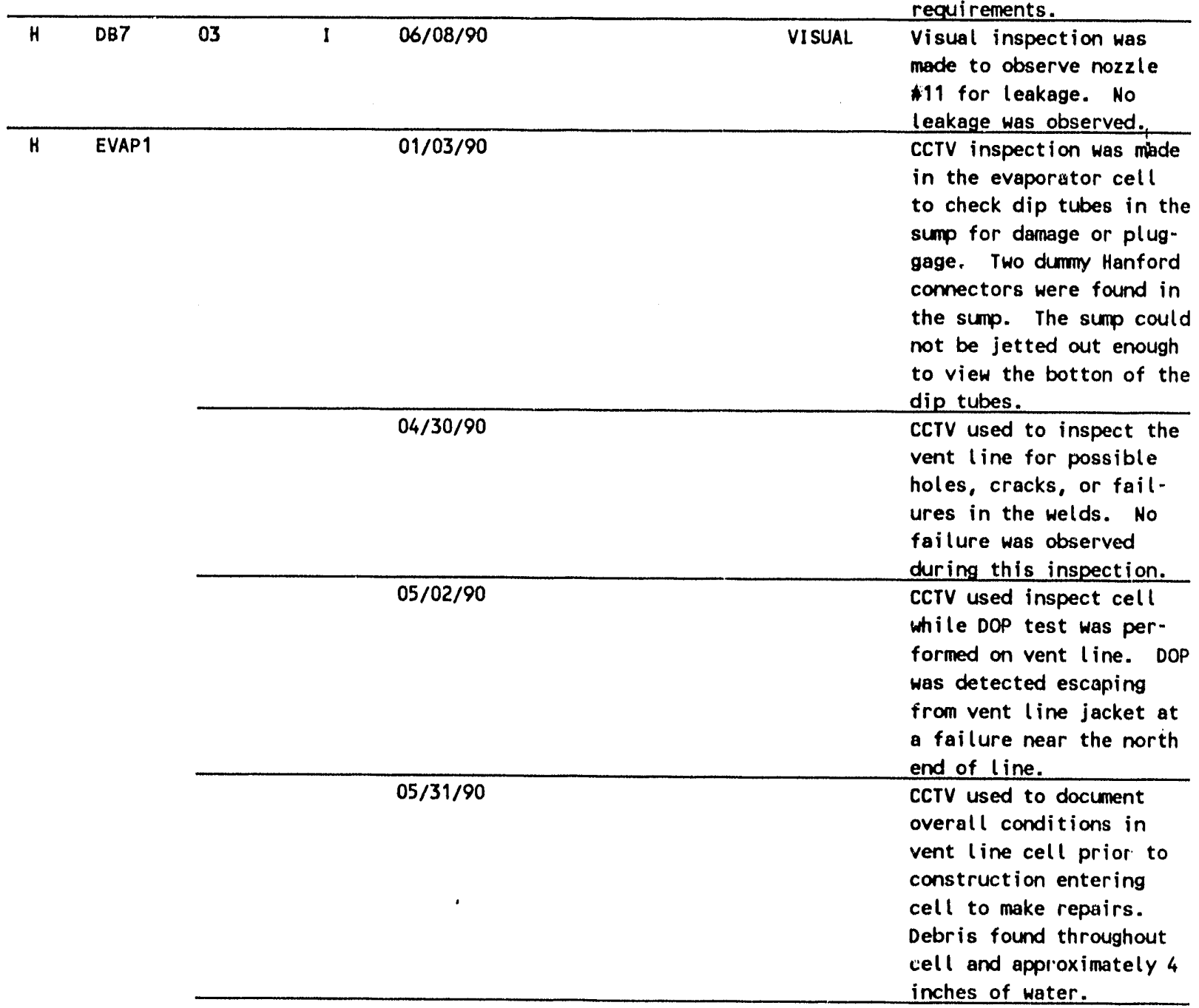


TABLE 1

SUMMARY OF INSPECTIONS

$\begin{array}{cccc}\begin{array}{c}\text { Tank Inspec- Annulus } \\ \text { or } \\ \text { tion }\end{array} \text { or } \\ \text { Area } & \frac{\text { Vessel }}{\text { EVAP1 }} \text { Port Interior } \frac{\text { Date }}{08 / 22 / 90} \text { WAP } & \begin{array}{c}\text { Type of Inspection and } \\ \text { Identification Numbers }\end{array}\end{array}$

CCTV used to document overall conditions of Evaporator cell and sump.

NW $08 / 29 / 90$
A CCTV inspection was made to determine if the east catheter line had been crimp sealed. No crimp was observed in the line.

The numbers listed under WAP, DP, and PSP identify photographs in the WMT files.

WAP $=$ wide angle photography; $D P=$ direct photography; $P S P=$ periscopic photography; $D B=$ diversion box; $E V A P=$ evaporator $; \quad C R C=$ cesium removal column 


\section{DISTRIBUTION}

1. Ambrose L. Schwallie, 703-A

2. Edward W. Pottmeyer, Jr., 703-A

3. Robert Maher, 703-A

4. D. L. McIntosh, 773-A

5. M. G. O'Rear, DOE-SR, 703-34A

6. C. E. Anderson, DOE-SR, 703-H

7. W. C. Reinig, 703-A

8. G. T. Wright, $703-\mathrm{H}$

9. S. S. Cathey, 703-H

10. R. G. Garvin, 703-H

11. T. M. Osborne, 703-H

12. R. A. Scaggs, 703-H

13. B. L. Lewis, 703-H

14. M. A. Ceravolo, 703-H

15. R. W. Wilson, 703-H

16. V. G. Dickert, 703-F

17. F. G. McNatt, $704-8 \mathrm{H}$

18. L. Kinard, 704-8H

19. WMT Inspection Records, 704-8H

20. WMT File, 703-H

File Code WM-190.3

21. Central Files (10), 703-A

22. Central Files Record Copy, 703-A 

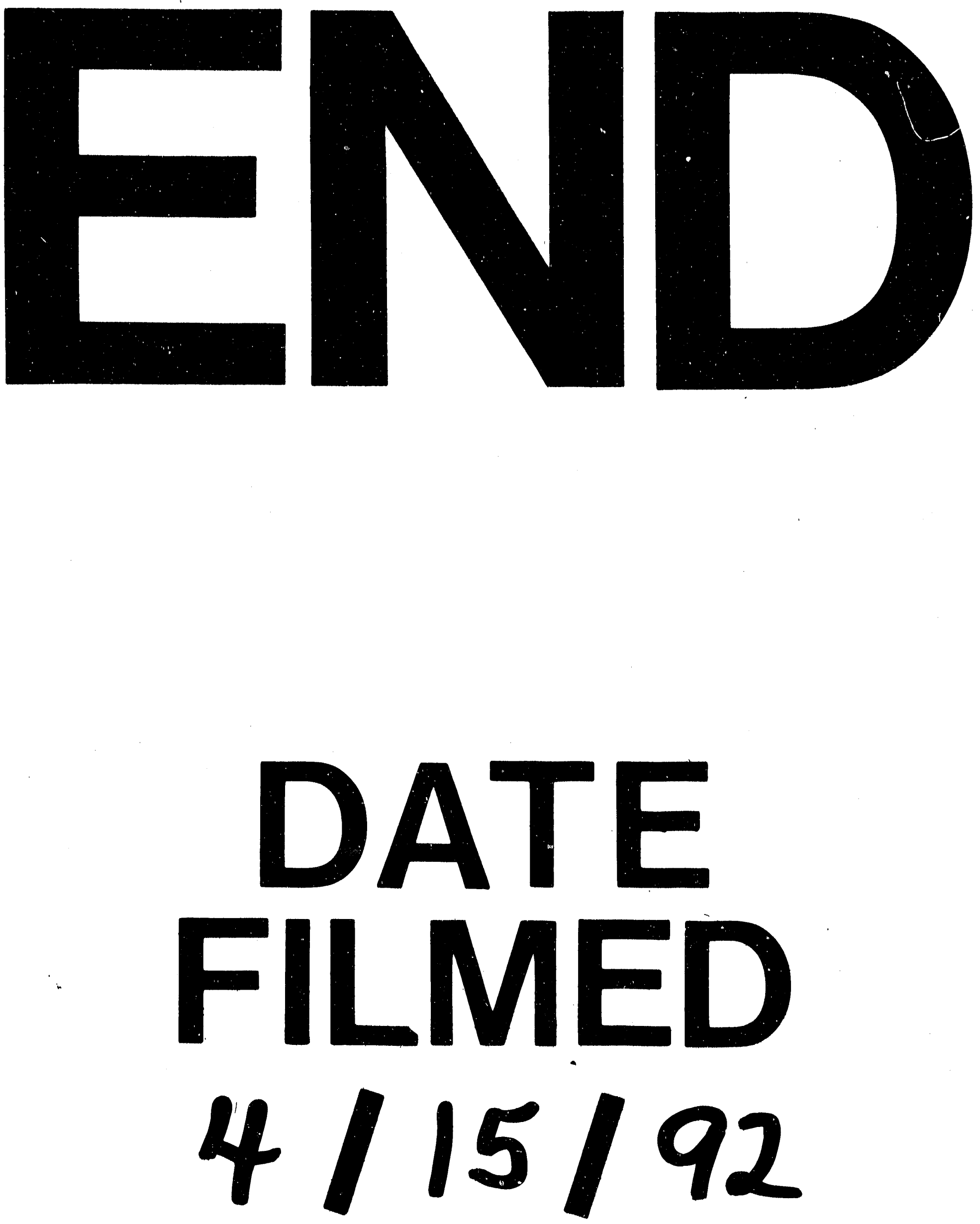
